\title{
Taxonomic novelties of saprobic Pleosporales from selected dicotyledons and grasses
}

\section{Brahmanage $\mathrm{RS}^{1,2,3}$, Dayarathne $\mathrm{MC}^{6}$, Wanasinghe $\mathrm{DN}^{4,5}$, Thambugala $\mathrm{KM}^{7}$, Jeewon $R^{8}$, Chethana KWT ${ }^{1,3}$, Samarakoon MC $^{1}$, Tennakoon DS $^{1,4,5}$, De Silva $\mathrm{NI}^{1,4,5}$, Camporesi $\mathrm{E}^{9,10,11}$, Raza $\mathrm{M}^{13}$, Yan $\mathrm{JY}^{2}$ and Hyde $\mathrm{KD}^{1,3,5,12}$}

\author{
${ }^{1}$ Center of Excellence in Fungal Research, Mae Fah Luang University, Chiang Rai, 57100, Thailand \\ ${ }^{2}$ Institute of Plant and Environment Protection, Beijing Academy of Agriculture and Forestry Sciences, Beijing 100097, \\ People's Republic of China \\ ${ }^{3}$ School of Science, Mae Fah Luang University, Chiang Rai, Chiang Rai, 57100, Thailand \\ ${ }^{4}$ World Agro forestry Centre East and Central Asia Office, 132 Lanhei Road, Kunming 650201, People's Republic of \\ China \\ ${ }^{5}$ CAS Key Laboratory for Plant Biodiversity and Biogeography of East Asia (KLPB), Kunming Institute of Botany, \\ Chinese Academy of Science, Kunming 650201, Yunnan, People's Republic of China \\ ${ }^{6}$ Department of Plant Pathology, Agriculture College, Guizhou University, Guiyang, Guizhou Province, 550025, \\ People's Republic of China \\ ${ }^{7}$ Genetics and Molecular Biology Unit, Faculty of Applied Sciences, University of Sri Jayawardenepura, Gangodawila, \\ Nugegoda, Sri Lanka \\ ${ }^{8}$ Department of Health Sciences, Faculty of Medicine and Health Sciences, University of Mauritius, Reduit, Mauritius. \\ ${ }^{9}$ A.M.B. Circolo Micologico "Giovanni Carini”, C.P. 314, Brescia, Italy \\ ${ }^{10}$ A.M.B. Gruppo, Micologico Forlivese "Antonio Cicognani", Via Roma 18, Forli, Italy \\ ${ }^{11}$ Società per gli Studi Naturalistici della Romagna, C.P. 143, Bagnacavallo, RA, Italy \\ ${ }^{12}$ Institute of Plant Health, Zhongkai University of Agriculture and Engineering, Haizhu District, Guangzhou 510225, \\ People's Republic of China \\ ${ }^{13}$ State Key Laboratory of Mycology, Institute of Microbiology, Chinese Academy of Sciences, Beijing, 100101, \\ People's Republic of China
}

Brahmanage RS, Dayarathne MC, Wanasinghe DN, Thambugala KM, Jeewon R, Chethana KWT, Samarakoon MC, Tennakoon DS, De Silva NI, Camporesi E, Raza M, Yan JY, Hyde KD 2020 Taxonomic novelties of saprobic Pleosporales from selected dicotyledons and grasses. Mycosphere 11(1), 2481-2541, Doi 10.5943/mycosphere/11/1/15

\begin{abstract}
Pleosporales is the largest order in the class Dothideomycetes, comprising a quarter of all species of Dothideomycetes. This paper provides comprehensive illustrations and descriptions of newly collected saprobic pleosporalean taxa from dicotyledons and grasses in China, Italy, Russia and Thailand. These species are accommodated in 8 families in Pleosporales. The taxa described here include 14 new species, a new geographical record and three new host records of known species. New species are Alternaria rumicis, Bambusicola ficuum, Comoclathris flammulae, $C$. europaeae, C. lonicerae, Ophiobolus lathyri, Paraophiobolus torilicola, Parastagonospora dactylidicola, P. hieracioidis, Pseudopaucispora hyalinospora, Stagonospora poaceicola, Stemphylium artemisiae and Subplenodomus meldolanus. All species descriptions presented herein are based on morphological comparisons coupled with multi-gene phylogenetic analyses.
\end{abstract}

Key words - 14 new species - Dothideomycetes - microfungi - phylogeny - taxonomy 


\section{Table of contents}

The pleosporalean taxa are organized as in the "Outline of fungi and fungus-like taxa" (Wijayawardene et al. 2020).

Ascomycota R.H. Whittaker

Pleosporomycetidae C.L. Schoch, Spatafora, Crous \& Shoemaker

Pleosporales Luttr. ex M.E. Barr

Bambusicolaceae D.Q. Dai \& K.D. Hyde

1. Bambusicola ficuum N.I. de Silva \& K.D. Hyde, sp. nov.

\section{Lentitheciaceae}

2. Keissleriella italica Brahmanage, Camporesi \& K.D. Hyde, sp. nov.

3. Pseudomurilentithecium clematidis Brahmanage, Camporesi \& K.D. Hyde, sp. nov.

\section{Leptosphaeriaceae}

4. Plenodomus biglobosus (Shoemaker \& H. Brun) Gruyter, Aveskamp \& Verkley, new host record 5. Plenodomus enteroleucus (Sacc.) Gruyter, Aveskamp \& Verkley, new host record

6. Subplenodomus meldolanus Brahmanage \& K.D. Hyde, sp. nov.

\section{Lophiostomataceae}

7. Pseudopaucispora hyalinospora Samarak. \& K.D. Hyde, sp. nov.

\section{Massarinaceae}

8. Stagonospora poaceicola Tennakoon, Phookamsak R \& K.D. Hyde, sp. nov.

\section{Morosphaeriaceae}

9. Helicascus chiangraiensis Z.L. Luo, J.K Liu, H.Y. Su \& K.D. Hyde, new geographical record

\section{Phaeospheriaceae}

10. Ophiobolus lathyri Brahmanage, Camporesi \& K.D. Hyde, sp. nov.

11. Paraophiobolus torilicola Brahmanage, Camporesi \& K.D. Hyde, sp. nov.

12. Parastagonospora dactylidicola Brahmanage, Camporesi \& K.D. Hyde, sp. nov.

\section{Pleosporaceae}

13. Alternaria rumicis Brahmanage, Camporesi \& K.D. Hyde, sp. nov.

14. Comoclathris europaeae Brahmanage, Camporesi \& K.D. Hyde, sp. nov.

15. Comoclathris flammulae Brahmanage, Camporesi \& K.D. Hyde, sp. nov.

16. Comoclathris lonicerae Brahmanage, Camporesi \& K.D. Hyde, sp. nov.

17. Stemphylium artemisiae Brahmanage, Camporesi \& K.D. Hyde, sp. nov.

18. Stemphylium vesicarium (Wallr.) E.G. Simmons, new host record

\section{Introduction}

Luttrell (1955) invalidly introduced Pleosporales, but it was sussequently validated by Barr (1987a) with Pleosporaceae as an important family and Pleospora Rabenh. ex Ces. \& De Not., as the type genus (currently synonymized under Stemphylium Wallr), (Wijayawardene et al 2017). The type species of Pleospora is P. herbarum (Barr 1987b). Previous studies indicated that the order comprises 20 families (Kodsueb et al. 2006, Boehm et al. 2009a, b, Mugambi \& Huhndorf 2009, Schoch et al. 2009, Shearer et al. 2009, Suetrong et al. 2009, Tanaka et al. 2009, Zhang et al. 2009) and later, Zhang et al. (2012) accepted 25 families in Pleosporales. Subsequent studies by 
Hyde et al. (2013), Wijayawardene et al. (2017, 2020) accepted 41, 75 and 87 families, respectively. In a recent treatment, Hongsanan et al. (2020) accepted 91 families. These pleosporalean species comprises pseudothecial ascomata with papilla and a peridium comprising several layers of cells (Zhang et al. 2008, 2009, 2012, Hyde et al. 2013, Jaklitsch \& Voglmayr 2016, Jaklitsch et al. 2018). Their asci are bitunicate, fissitunicate and exist within a persistent hamathecium with or without pseudoparaphyses (Ariyawansa et al. 2014, 2015a, b, c, Hyde et al. 2013). Ascospores are septate with differences in color and shape and with or without a gelatinous sheath (Zhang et al. 2009, 2012, Hyde et al. 2013, Jaklitsch \& Voglmayr 2016, Jaklitsch et al. 2018). Members of Pleosporales can be found in different habitats, as epiphytes, endophytes, saprobes, parasites, hyperparasites on fungi or insects and as lichenized fungi (Ramesh 2003, Jeewon et al. 2013, 2017, Kruys et al. 2006, Pinnoi et al. 2007, Zhang et al. 2012, Ariyawansa et al. 2014, Li et al. 2017, Hyde at al. 2018, Jayasiri et al. 2019). Asexual morphs of Pleosporales can be either coelomycetes or hyphomycetes (Heidari et al. 2018, Li et al. 2020). Camarosporium-like, coniothyrium-like, phaeosphaeria-like, phoma-like, pyrenochaeta-like, and septoria-like asexual morphs are the most common forms of coelomycetes in Pleosporales. These taxa are polyphyletic within the order (Wijayawardene et al. 2016, Li et al. 2020).

Many new pleosporalean lineages from freshwater (Brahmanage et al. 2017, Luo et al. 2018), marine (Devadatha et al. 2018, Jones et al. 2019, Dayarathne et al. 2020) and terrestrial habitats (Tanaka et al. 2009, Wanasinghe et al. 2017a, 2018a, Zhang et al. 2019) have been recently documented. Phylogenetic analyses have shown that the placement of a large number of taxa is still unresolved, and there is a need to reconsider their classification (Wang et al. 2007, Pem et al. 2019). For example, Kruys et al. (2006) and Zhang et al. (2012) documented that Venturiaceae have a set of morphological and ecological characters, which are dissimilar to other Pleosporales members. Phylogenetic results of Schoch et al. (2009) indicated that members of Venturiaceae form a well-supported clade distant from the core members of Pleosporales, and excluded it from Pleosporomycetidae and Dothideomycetidae. Zhang et al. (2012) therefore introduced the new order, Venturiales. Other families, such as Zopfiaceae (as Testudinaceae) have also been shown to be unrelated to Pleosporales based on rDNA sequence data (Kodsueb et al. 2006). Tanaka et al. (2015) revised their taxonomy based on DNA sequence data from protein-coding regions for the suborder Massarineae. Given that the Pleosporales is highly diverse with many more new species awaiting to be discovered in the tropics (Hyde et al. 2018), there is a need to revise their taxonomy (especially with regards to the nomenclature of old species) with fresh collections (Dayarathne et al. 2016, Pem et al. 2019).

\section{Economic significance of pleosporalean taxa}

Phoma is an example of a coelomycetous genus, which are associated with a wide range of terrestrial plants, causing stem and leaf spots (Aveskamp et al. 2008, Zhang et al. 2009). At least $50 \%$ of the Phoma taxa re-described by Boerema et al. (2004) have been recognized as phytopathogenic species with plant quarantine issues (Boerema et al. 2004, Aveskamp et al. 2008, Chen et al. 2015). Although most of the taxa exist in the environment as saprobic soil organisms, many species can switch to a pathogenic lifestyle once the favourable conditions received (Aveskamp et al. 2008, Promputtha et al. 2007, Jayawardena et al. 2019b). Some Phoma species are pathogens of humans and other vertebrates, such as cattle (Costa et al. 1993, De Hoog et al. 2000) and fish (Voronin, 1989, Faisal et al. 2007). Furthermore, Phoma spp. can indirectly affect animal health by producing toxic secondary metabolites (Rabie et al. 1975, Bennett 1983, Pedras \& Biesenthal 2000, Rai et al. 2009, Sørensen et al. 2011). One of the most unexplored habitats for Phoma species is the marine environment (Kohlmeyer \& Volkmann-Kohlmeyer 1991, Osterhage et al. 2000, Yarden et al. 2007) and several species have been listed from mangroves which need reexamining (Dayarathne et al. 2020).

Stemphylium species are saprobes (Han et al. 2019), but also occur on crops such as alfalfa (Medicago sativa L.), red clover (Trifolium pratense L.), potato (Solanum tuberosum L.), tomato (Solanum lycopersicum L.) (Ellis \& Gibson 1975, Irwin 1984, Johnson \& Lunden 1986, Simmons 
et al. 1990, Aveling \& Snyman 1993), sugar beet (Hanse 2013), asparagus, garlic, onion (Gálvez et al. 2016), bird's-foot trefoil (Lotus corniculatus) (Seaney 1973), lentil, lucerne, pear, parsley (Medicago sativa) and a variety of other horticultural crops (Miller et al. 1978, Lamprecht et al. 1984, Falloon et al. 1987, Llorente \& Montesinos 2006, Reis et al. 2011, Nasehi et al. 2013, Vakalounakis \& Markakis 2013, Subedi et al. 2014). Stemphylium vesicarium causes leaf spots in onion and garlic and purple spots in asparagus (Gálvez et al. 2016). Stemphylium solani is responsible for grey leaf spot on tomato and potato (Ellis \& Gibson 1975, Irwin 1984, Johnson \& Lunden 1986, Simmons et al. 1990, Aveling \& Snyman 1993). Stemphylium loti has been reported as the causative agent of the bird's-foot trefoil foliar disease (Seaney 1973). Stemphylium pathogens have been found from several vegetables and flowers, including aster, Chinese chives, sweet pepper, tomato, Welsh onion, and white lace flower (Enjoji 1931, Suzui 1973, Ichikawa \& Sato 1994, Tomioka et al. 1997, Shibata et al. 2000, Misawa 2009, Tomioka \& Sato 2011, Kurose et al. 2015, Brahmanage et al. 2019). Species of Alternaria are serious plant pathogens that trigger diseases on an extensive variety of crops, and some are important as postharvest pathogens, human pathogens which causes phaeohyphomycosis in immuno-compromised patients or act as airborne allergens (Woudenberg et al. 2013, 2015). Pleosporales also comprises species and varieties that are recognized as fungicolous, lichenicolous and endophytes (Xianshu et al. 1994, Hawksworth 2004, Schoch et al. 2009, Sun et al. 2019).

Recognition of plant-associated fungi is often hindered by the lack of morphological characters described or illustrated in the original publications and the endophytic or inconspicuous nature of pleosporalean taxa. DNA sequence data provide reliable information for diagnostic purposes of pathogens (Hyde et al. 2013, Jayawardena et al. 2019a, b).

\section{Aim of the paper}

This paper reports on the taxonomy of saprobic pleosporalean taxa on dicotyledons and identifies the species using morphology and multi-locus phylogenies. We also establish possible links between the asexual and sexual morphs. This study is a continuity of our studies on bitunicate fungi (Wanasinghe et al. 2017, Jayasiri et al. 2019, Pem et al. 2019, Hyde et al. 2020) and is an additional taxonomic contribution, where we recover novel saprobic pleosporalean taxa associated with dicotyledons.

\section{Materials and Methods}

\section{Sample collections}

Plant samples with pleosporalean taxa were collected from selected dicotyledons and grasses in China, Italy, Russia and Thailand from 2017 to 2019. Materials were labeled and brought to the laboratory in plastic Ziplock bags. These substrata were branches, fruits, roots, twigs and small parts cut from tree stems that are variable in size, length, color, texture and at different stages of decomposition.

\section{Incubation and specimen examination}

Samples were incubated in plastic containers with moistened sterilized tissue at $16-25^{\circ} \mathrm{C}$ for one week and then the fruiting bodies were examined using a dissecting microscope. Squash mounts and sections of the fruiting structures were mounted in water and stained with Melzer's reagent, Indian ink or Congo red, when necessary for microscopic studies and photomicrography. Morphological characteristics of fungi were examined using a Nikon ECLIPSE 80i compound microscope and photographed by a Canon EOS 550D digital camera fitted to the microscope or Nikon, NIS-Elements F3.0. Measurements such as the diameter of ascomata, length and width of asci and ascospores and width of pseudoparaphyses were made with the Tarosoft Image Frame Work program and images use for figures were processed with Adobe Photoshop CS3 Extended version 10.0 software (Adobe Systems Inc., US).

\section{Isolation of pleosporalean fungi}


For single spore isolation, a modified method of Chomnunti et al. (2014) was followed. Contents of the sectioned fruiting body were transferred to a drop of sterile water on a flamesterilized slide. Drops of the spore suspension were pipetted and spread on a Petri-dish containing $2 \%$ water agar (WA). Then the plates were incubated at $10-30^{\circ} \mathrm{C}$ overnight. Germinated ascospores or conidia were transferred to potato dextrose agar (PDA) or malt extract agar (MEA).

\section{Cultures and herbarium specimens}

Cultures and herbarium specimens of isolated fungi were deposited in the Mae Fah Luang University culture collection (MFLUCC) and Mae Fah Luang University Herbarium (Herb. MFLU), Thailand respectively. Their duplicates were deposited at the Beijing Academy of Agricultural and Forestry Sciences (JZB), China and the Herbarium of Cryptogams Kunming Institute of Botany Academia Sinica (KUNHKAS), China. Facesoffungi numbers (FoF) and Index Fungorum (IF) numbers were obtained as explained by Jayasiri et al. (2015) and Index Fungorum (2020). New species are established based on the recommendations by Jeewon \& Hyde (2016).

\section{DNA extraction, Polymerase chain reactions (PCR) and sequencing}

Mycelia (approximately $50 \mathrm{mg}$ ) were harvested from the fungal cultures grown on PDA, MEA or seawater PDA and extracted genomic DNA using EZ gene TM fungal gDNA kit (GD2416). When fungi failed to grow in culture, DNA was extracted directly from fruiting bodies following the method described by Zeng et al. (2018) and Wanasinghe et al. (2018b) using E.Z.N.A. (® Forensic DNA kit (D3591- 01, Omega Bio-Tek) according to manufacturer instructions. DNA amplifications were performed by polymerase chain reaction (PCR). Six loci were amplified including rDNA ITS (White et al. 1990), LSU, SSU (Vilgalys \& Hester 1990), RPB2 (Liu et al. 1999), TEF1 (Carbone \& Kohn 1999), GAPDH (White et al. 1990) and TUB2 (O'Donnell \& Cigelnik 1997). The primers and PCR protocols are listed in Table 1. Amplifications were performed in $25 \mu \mathrm{l}$ of PCR mixtures, containing $9.5 \mu \mathrm{l}$ of $\mathrm{ddH}_{2} \mathrm{O}, 12.5 \mu \mathrm{l}$ of PCR Master Mix, $1 \mu \mathrm{l}$ of DNA template, and $1 \mu \mathrm{l}$ of each primer $(10 \mathrm{pM})$. The PCR products were visualized under UV light on $1 \%$ agarose electrophoresis gels stained with $4 \mathrm{~S}$ green stain or ethidium bromide using the Gel Doc XR+Molecular Imager (BIO-RAD, USA). Purification and sequencing of PCR products were carried out at Sun biotech Company, Beijing, China. DNA sequences generated in this study were deposited in the GenBank for further studies.

\section{Phylogenetic analysis}

New sequence data and the related sequences obtained from Genbank were aligned in MAFFT v. 6.864b (http://mafft.cbrc.jp/alignment/server/index.html; Katoh et al. 2019) edited and improved using Bioedit v.7 (Hall 1999) and MEGA 5.0 (Tamura et al. 2013). Maximum likelihood (ML) and Bayesian inference analysis (BI) analyses were performed. ML analyses were performed using raxmlGUI version 1.3 (Silvestro \& Michalak 2012). The optimal ML tree search was searched with 1000 separate runs, using the default algorithm of the program from a random starting tree for each run. The final tree was selected among suboptimal trees from each run by comparing the likelihood scores under the GTRGAMMA substitution model. The best scoring tree was selected. BI analyses were performed using MrBayes v. 3.0b4 (Ronquist \& Huelsenbeck 2003), and nucleotide substitution model were determined with MrModeltest v. 2.2 (Nylander 2004). Posterior probabilities (PP) (Rannala \& Yang 1996, Zhaxybayeva \& Gogarten 2002) were defined by Bayesian Markov Chain Monte Carlo (BMCMC) sampling method in MrBayes v. 3.0b4 (Huelsenbeck \& Ronquist 2001). Resulting trees were visualized with TreeView v. 1.6.6 (Rambaut 2012).

\section{Taxonomy}

Ascomycota R.H. Whittaker 
We follow the latest treatments and updated accounts of Ascomycota in Wijayawardene et al. (2020).

Class Dothideomycetes sensu O.E. Erikss \& Winka

Dothideomycetes is considered to be the largest and most phylogenetically diverse class in the phylum Ascomycota (Schoch et al. 2009, Hyde et al. 2013). Liu et al. (2017) provided the divergence time estimations at different levels for the class Dothideomycetes and reported that divergence times can provide additional evidence to support the establishment of higher-level taxa, such as families, orders and classes. The subclasses of Dothideomycetes and their families reported in this study are listed in alphabetical order.

Table 1 Genes/loci used in the study with respective PCR primers and protocols

\begin{tabular}{|c|c|c|c|c|c|c|c|c|}
\hline \multirow[b]{2}{*}{ Gene/loci } & \multicolumn{2}{|c|}{ Primer } & \multicolumn{5}{|c|}{ PCR protocol } & \multirow[b]{2}{*}{ Reference } \\
\hline & Forward & Reverse & $\begin{array}{l}\text { Initial } \\
\text { Denaturation }\end{array}$ & Denaturation & Annealing & Extension & $\begin{array}{l}\text { Final } \\
\text { extension }\end{array}$ & \\
\hline $\begin{array}{l}\text { Internal transcribed spacer } \\
\text { (ITS) }\end{array}$ & ITS5 & ITS4 & $\begin{array}{l}94^{\circ} \mathrm{C}, 4 \mathrm{~min} \\
1 \text { cycle }\end{array}$ & $\begin{array}{l}94^{\circ} \mathrm{C}, 45 \mathrm{sec} \\
35 \text { cycles }\end{array}$ & $56^{\circ} \mathrm{C}, 45 \mathrm{sec}$ & $72^{\circ} \mathrm{C}, 1 \mathrm{~min}$ & $\begin{array}{l}72^{\circ} \mathrm{C}, 10 \mathrm{~min} \\
1 \text { cycle }\end{array}$ & White et al. (1990) \\
\hline Large subunit (LSU) & LROR & LR5 & $\begin{array}{l}94^{\circ} \mathrm{C}, 4 \mathrm{~min} \\
1 \text { cycle }\end{array}$ & $\begin{array}{l}94^{\circ} \mathrm{C}, 45 \mathrm{sec} \\
35 \text { cycles }\end{array}$ & $56^{\circ} \mathrm{C}, 45 \mathrm{sec}$ & $72^{\circ} \mathrm{C}, 1 \mathrm{~min}$ & $\begin{array}{l}72^{\circ} \mathrm{C}, 10 \mathrm{~min} \\
1 \text { cycle }\end{array}$ & $\begin{array}{l}\text { Rehner \& Samuels (1994) } \\
\text { Vilgalys \& Hester (1990) }\end{array}$ \\
\hline Small subunit (SSU) & NS1 & NS4 & $\begin{array}{l}94^{\circ} \mathrm{C}, 4 \mathrm{~min} \\
1 \text { cycle }\end{array}$ & $\begin{array}{l}94^{\circ} \mathrm{C}, 45 \mathrm{sec} \\
35 \text { cycles }\end{array}$ & $56^{\circ} \mathrm{C}, 45 \mathrm{sec}$ & $72^{\circ} \mathrm{C}, 1 \mathrm{~min}$ & $\begin{array}{l}72^{\circ} \mathrm{C}, 10 \mathrm{~min} \\
1 \text { cycle }\end{array}$ & White et al. (1990) \\
\hline $\begin{array}{l}\text { Elongation factor-1 alpha } \\
\text { (TEF1) }\end{array}$ & EF1-728F & EF1- 986R & $\begin{array}{l}94^{\circ} \mathrm{C}, 3 \mathrm{~min} \\
1 \text { cycle }\end{array}$ & $\begin{array}{l}94^{\circ} \mathrm{C}, 30 \mathrm{sec} \\
35 \text { cycles }\end{array}$ & $55^{\circ} \mathrm{C}, 50 \mathrm{sec}$ & $72^{\circ} \mathrm{C}, 1 \mathrm{~min}$ & $\begin{array}{l}72^{\circ} \mathrm{C}, 10 \mathrm{~min} \\
1 \text { cycle }\end{array}$ & Carbone \& Kohn (1999) \\
\hline $\begin{array}{l}\text { RNA polymerase II second } \\
\text { largest subunit (RBP2) }\end{array}$ & fRPB2-5F & fRPB2-7cr & $\begin{array}{l}95^{\circ} \mathrm{C}, 5 \mathrm{~min} \\
1 \text { cycle }\end{array}$ & $\begin{array}{l}95^{\circ} \mathrm{C}, 45 \mathrm{sec} \\
40 \text { cycles }\end{array}$ & $55^{\circ} \mathrm{C}, 2 \mathrm{~min}$ & $72^{\circ} \mathrm{C}, 1.5 \mathrm{~min}$ & $\begin{array}{l}72^{\circ} \mathrm{C}, 10 \mathrm{~min} \\
1 \text { cycle }\end{array}$ & Liu et al. (1999) \\
\hline Beta tubulin ( $\beta$-tubulin) & $\mathrm{Bt} 2 \mathrm{a}$ & $\mathrm{Bt} 2 \mathrm{~b}$ & $\begin{array}{l}94^{\circ} \mathrm{C}, 3 \mathrm{~min} \\
1 \text { cycle }\end{array}$ & $\begin{array}{l}94^{\circ} \mathrm{C}, 30 \mathrm{sec} \\
35 \text { cycles }\end{array}$ & $55^{\circ} \mathrm{C}, 50 \mathrm{sec}$ & $72^{\circ} \mathrm{C}, 1 \mathrm{~min}$ & $\begin{array}{l}72^{\circ} \mathrm{C}, 10 \mathrm{~min} \\
1 \text { cycle }\end{array}$ & Glass \& Donaldson (1995) \\
\hline $\begin{array}{l}\text { Glyceraldehyde-3-phosphate } \\
\text { dehydrogenase (GADPH) }\end{array}$ & gpd1 & $\operatorname{gpd} 2$ & $\begin{array}{l}94^{\circ} \mathrm{C}, 5 \mathrm{~min} \\
1 \text { cycle }\end{array}$ & $\begin{array}{l}94^{\circ} \mathrm{C}, 30 \mathrm{sec} \\
35 \text { cycles }\end{array}$ & $59^{\circ} \mathrm{C}, 30 \mathrm{sec}$ & $72^{\circ} \mathrm{C}, 1 \mathrm{~min}$ & $\begin{array}{l}72^{\circ} \mathrm{C}, 7 \mathrm{~min} \\
1 \text { cycle }\end{array}$ & Berbee et al. (1999) \\
\hline
\end{tabular}

Subclass Pleosporomycetidae C.L. Schoch et al.

Bambusicolaceae D.Q. Dai \& K.D. Hyde

Bambusicolaceae was introduced by Hyde et al. (2013) with four genera, viz. Bambusicola D.Q. Dai \& K.D. Hyde, Leucaenicola Jayasiri, E.B.G. Jones \& K.D. Hyde, Neobambusicola Crous \&amp; M.J. Wingf. and Palmiascoma Phookamsak \&amp; K.D. Hyde (Liu et al. 2015, Wijayawardene et al. 2018, Jayasiri et al. 2019). Later, Wijayawardene et al. (2020) accepted Neobambusicola in Sulcatisporaceae. Bambusicolaceae shares similar morphological characteristics with some families in Pleosporales (i.e. Didymosphaeriaceae, Massarinaceae and Tetraplosphaeriaceae), in having cylindrical to clavate asci and fusiform to 
ellipsoidal, hyaline to brown, 1-septate ascospores (Dai et al. 2015). Bambusicolaceae differs from related families with asexual morph having holoblastic, annelidic or phialidic conidiogenous cells (Dai et al. 2015).

\section{Bambusicola D.Q. Dai \& K.D. Hyde}

Bambusicola D.Q. Dai \& K.D. Hyde was introduced and typified with B. massarinia D.Q. Dai \& K.D. Hyde (Dai et al. 2012), and was previously placed in Trematosphaeriaceae based on ribosomal LSU gene sequence analysis. The genus is known for its asexual and sexual morphs. Hyde et al. (2013) provided a combined phylogenetic analysis of LSU, SSU, RPB2 and TEF1 data for the families in Dothideomycetes. Species of Bambusicola aggregated into a separate clade from other families in Massarineae, for which Hyde et al. (2013) introduced the new family Bambusicolaceae. We herein introduce a novel Bambusicola species from Thailand.

Bambusicola ficuum N.I. de Silva \& K.D. Hyde, sp. nov.

Fig. 2

Index Fungorum number: IF 557332; Facesoffungi number: FoF 07740

Etymology - The specific epithet reflects the host Ficus sp.

Holotype - MFLU 17-0677

Saprobic on dead twigs of Ficus sp. Sexual morph: Ascomata 140-200 $\mu \mathrm{m}$ high, 165-210 $\mu \mathrm{m}$ diam. $(\overline{\mathrm{x}}=155 \times 180 \mu \mathrm{m}, \mathrm{n}=10)$, immersed to semi-immersed on host surface, solitary, globose to sub-globose, dark brown. Neck small, short, elongate, and central with minute papilla. Peridium 20-30 $\mu \mathrm{m}$ wide, unequally thick, comprises two layers, outer 1-3 cell layers of hyaline to brown textura angularis cells and inner 1-4 cell layers of hyaline textura prismatica cells. Hamathecium comprising 1-2 $\mu \mathrm{m}$ wide, cylindrical to filiform, septate, pseudoparaphyses. Asci 90-140 × 17-24 $\mu \mathrm{m}(\overline{\mathrm{x}}=120 \times 20 \mu \mathrm{m}, \mathrm{n}=20), 8$-spored, bitunicate, fissitunicate, cylindric-clavate to clavate, short pedicellate, apically rounded, with an ocular chamber. Ascospores $42-50 \times 6-9 \mu \mathrm{m}(\overline{\mathrm{x}}=47 \times 7 \mu \mathrm{m}$, $\mathrm{n}=30$ ), overlapping bi-seriate or multi- seriate, hyaline, fusiform, with rounded to acute ends, 1 septate, constricted at the septum, upper cell larger than lower cell, smooth-walled, hyaline, guttulate, surrounded by a mucilaginous sheath. Asexual morph: Undetermined.

Culture characteristics - Colonies on PDA reaching $25 \mathrm{~mm}$ diameter after 1 week at 20$25^{\circ} \mathrm{C}$, colonies medium sparse, circular, surface slightly rough with edge entire, cottony to fairly fluffy with sparse aspects, colony from above: yellowish white; reverse: brown at the center and yellow at the margin.

Material examined - THAILAND, Chiang Mai Province, Mae Tang district, Ban Pa Deng, Mushroom Research Center, dead twigs (attached to the tree) of Ficus sp. (Moraceae), 25 January 2017, N. I. de Silva, NI108 (MFLU 17-0677, holotype), ex-type living culture, MFLUCC 17-0872.

GenBank Numbers - LSU: MT215580; SSU: MT215581; TEF1: MT199326

Notes - Bambusicola ficuum shows a close phylogenetic affinity to $B$. dimorpha and $B$. pustulata (Fig. 1). There are six base pair differences in TEF nucleotide sequences between Bambusicola ficuum and B. pustulata $(0.87 \%)$. The TEF sequence data for Bambusicola dimorpha is not available for the current phylogenetic analyses. Morphologically, Bambusicola ficuum differs from B. dimorpha and B. pustulata in having longer ascospores $(42-50 \mu \mathrm{m})$ with sheath, in contrast to the longer ascospores without sheath in Bambusicola dimorpha $(17-25 \mu \mathrm{m})$ and $B$. pustulata (11-17 $\mu \mathrm{m})$. Bambusicola dimorpha was collected in Chiang Mai Province, Thailand on dead bamboo culms (Thambugala et al 2017), while B. pustulata was reported in Phang-Nga Province, Thailand on dead bamboo culms (Dai et al. 2015). The new strain, Bambusicola ficuum was collected in Chiang Mai Province, Thailand on dead twigs of Ficus sp.

Lentitheciaceae Y. Zhang ter et al.

Lentitheciaceae was introduced by Zhang et al. (2009) with Lentithecium fluviatile (Aptroot \& Van Ryck.) K.D. Hyde, J. Fourn. \& Ying Zhang as the type species. Wanasinghe et al. (2014) listed six genera under this family and 14 genera are accepted in Wijayawardene et al. (2020). 


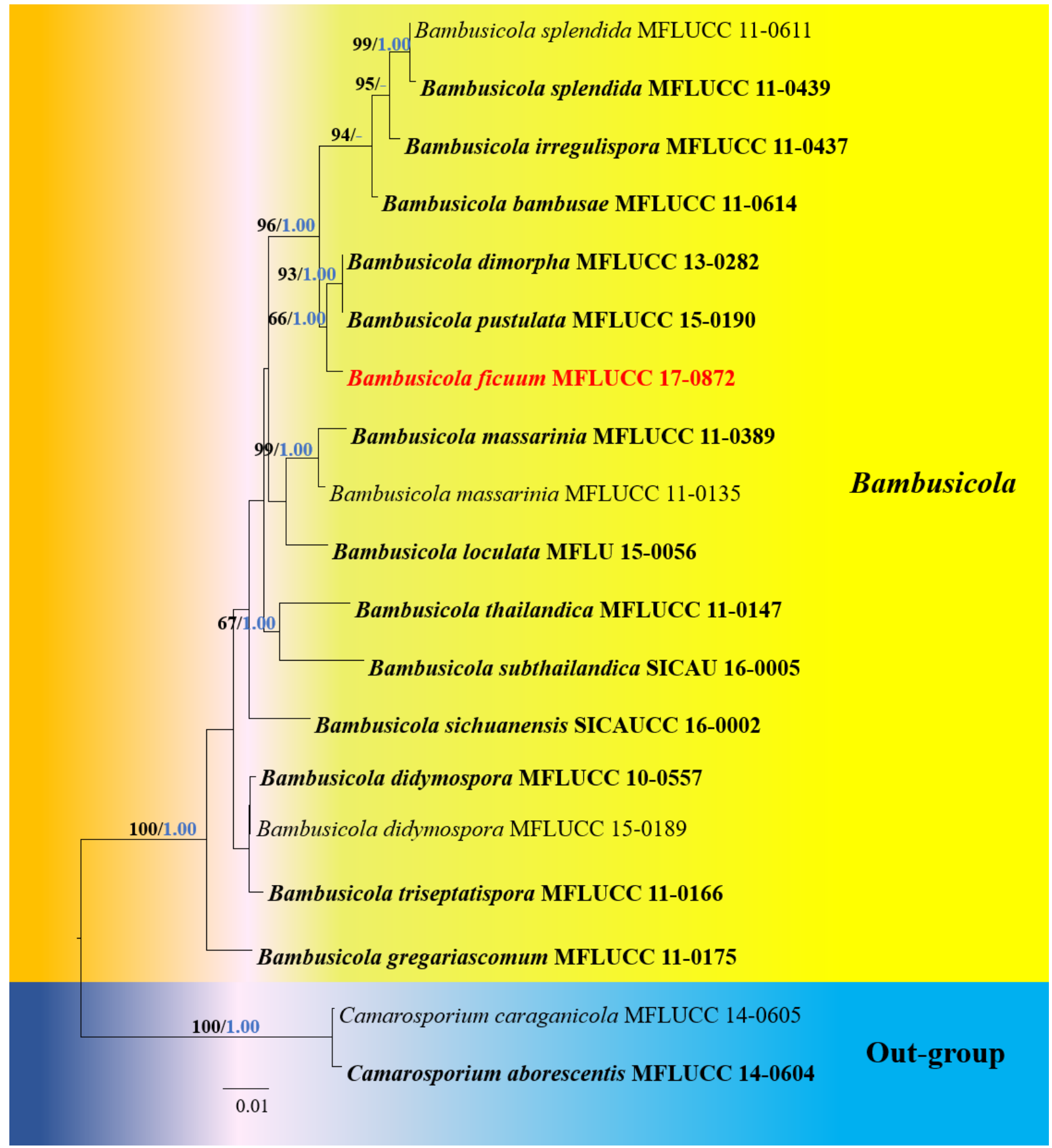

Figure 1 - Maximum likelihood analysis with 1000 bootstrap replicates yielded a best tree with the likelihood value of -6126.199615. The combined LSU, SSU and TEF sequence datasets comprised 19 strains of Bambusicola with Camarosporium aborescentis (MFLUCC 14-0604) and Camarosporium caraganicola (MFLUCC 14-0605) as the outgroup taxa. Tree topology of the ML analysis was similar to the BI. The matrix had 310 distinct alignment patterns, with $21.56 \%$ of undetermined characters or gaps. Estimated base frequencies were as follows; $\mathrm{A}=0.239116, \mathrm{C}=$ $0.247058, \mathrm{G}=0.277564, \mathrm{~T}=0.236262$; substitution rates $\mathrm{AC}=0.583379, \mathrm{AG}=2.265165, \mathrm{AT}=$ $0.909124, \mathrm{CG}=0.754568, \mathrm{CT}=11.365613, \mathrm{GT}=1.000000$; gamma distribution shape parameter $\alpha=0.020000$. Maximum likelihood bootstrap (ML, black) values equal to or greater than $65 \%$ and Bayesian posterior probabilities (PP, blue) equal to or greater than $0.90 \%$ are given above the nodes. The scale bar indicates 0.01 changes. The ex-type strains are in black bold and new isolates in red bold. 

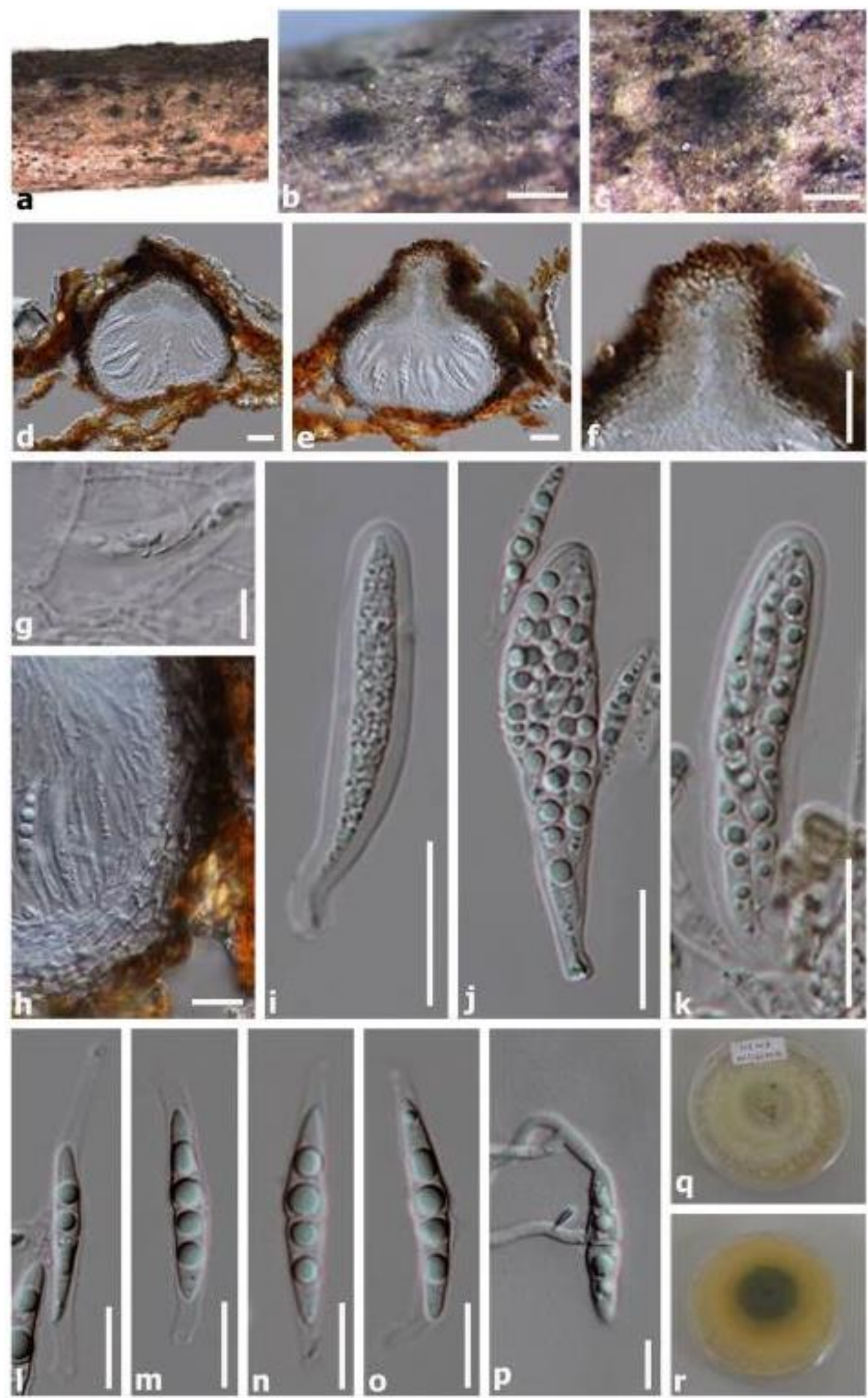

Figure 2 - Bambusicola ficuum (MFLU 17-0677, holotype). a Apices of ascomata. $\mathrm{b}$, c Appearance of ascomata on the host material. d, e, f Section through an ascoma. g Pseudoparaphyses. h Peridium. i-k. Asci l-o Ascospores. p Germinating ascospore. q Culture on PDA upper view. $r$ Culture on PDA lower view. Scale bars: $b, c=100 \mu \mathrm{m}, \mathrm{d}-\mathrm{f}=50 \mu \mathrm{m}, \mathrm{g}, \mathrm{h}=20$ $\mu \mathrm{m}, \mathrm{i}-\mathrm{k}=30 \mu \mathrm{m}, 1-\mathrm{p}=20 \mu \mathrm{m}$. 


\section{Keissleriella Höhn.}

Höhnel (1919) introduced Keissleriella to accommodate K. aesculi (Höhn.) Höhn. (三 Pyrenochaeta aesculi Höhn.). This genus is characterized by ascomata with ostiolar necks filled with black setae, and one to multi-septate, hyaline to pale brown ascospores (Barr 1990, Liu et al. 2015, Wanasinghe et al. 2018b, Phookamsak et al. 2019). The asexual morph comprises unbranched or branched, smooth, flexuous, hyaline conidiophores, phialidic conidiogenous cells and hyaline to brown, aseptate or septate conidia (Hyde et al. 2020). Munk (1957) placed Keissleriella in Lophiostomataceae, and then von Arx \& Muller (1975) included it in Pleosporaceae. Subsequently, Barr (1990) placed it in Melanommataceae, while Lumbsch \& Huhndorf (2007) transferred Keissleriella in to Massarinaceae. Zhang et al. (2009) included the genus in Lentitheciaceae, and this is followed by many subsequent authors (Zhang et al. 2012, Hyde et al. 2013, Wijayawardene et al. 2014, Tanaka et al. 2015, Wanasinghe et al. 2017b, 2018b, Phookamsak et al. 2019, Hyde et al. 2020).

Keissleriella italica Brahmanage, Camporesi \& K.D. Hyde, sp. nov.

Fig. 4

Index Fungorum number: IF557623; Facesoffungi number: FoF 08006

Etymology - Epithet refers to the country, Italy where the specimen was collected.

Holotype - MFLU 20-0394

Saprobic on dead aerial stems of Brassica sp. (Brassicaceae). Sexual morph: Ascomata 120 $240 \times 110-120 \mu \mathrm{m}(\overline{\mathrm{x}}=210 \times 105 \mu \mathrm{m})$, immersed to semi-immersed, appearing as black raised spots on the host, solitary, globose to subglobose, uniloculate, black, ostiolate with papilla filled with black setae. Peridium 18-25 $\mu \mathrm{m}$ wide, composed of 4-6 layers of pale brown to brown cells of textura angularis. Hamathecium comprising numerous, $0.8-1.3 \mu \mathrm{m}$ wide, cellular, branched, septate, anastomosed pseudoparaphyses. Asci 50-70 $\times 12-18 \mu \mathrm{m}(\overline{\mathrm{x}}=60 \times 16 \mu \mathrm{m}, \mathrm{n}=20)$, bitunicate, 8-spored, clavate, rounded at the apex with a short furcate pedicel. Ascospores $8-10 \times$ $2-3 \mu \mathrm{m}(\overline{\mathrm{x}}=8.5 \times 2.5 \mu \mathrm{m}, \mathrm{n}=20)$, overlapping uniseriate to biseriate, fusiform, hyaline, 1 -septate, constricted at the septum, smooth-walled, guttulate and lacks a sheath. Asexual morph: Undetermined.

Material examined - ITALY, Province of Forlì-Cesena [FC], Forlì, via Correcchio, on dead aerial stems of Brassica sp. (Brassicaceae), 24 February 2018, E. Camporesi, IT 3746 (MFLU 200394, holotype; JZBH3490001, isotype).

GenBank Accessions - LSU: MT370427; SSU: MT370371

Notes - Keissleriella italica is typical of Keissleriella with its ostiolar neck, and fusiform, septate ascospores (Munk 1953, Tanaka et al. 2015). Keissleriella italica clustered sister to K. dactylidicola Mapook, Camporesi \& K.D. Hyde and K. phragmiticola Wanas., E.B.G. Jones \& K.D. Hyde with relatively poor bootstrap support (Fig. 3). Keissleriella italica has smaller ascomata $(120-240 \times 110-120 \mu \mathrm{m} v s$ 160-210 × 200-230 $\mu \mathrm{m} v s \quad 400-500 \times 400-450 \mu \mathrm{m})$, asci $(50-70 \times 12-18 \mu \mathrm{m} v s 60-80 \times 8-10 \mu \mathrm{m} v s$ 120-160 $\times 16-20 \mu \mathrm{m})$ and ascospores $(8-10 \times 2-3 \mu \mathrm{m}$ vs $15-19 \times 4-5 \mu \mathrm{m}$ vs 35-50 $\times 7-11 \mu \mathrm{m})$ than that of $K$. dactylidicola and $K$. phragmiticola, respectively (Ariyawansa et al. 2015a, Wanasinghe et al. 2018a). Further, K. dactylidicola has surrounded by a hyaline, gelatinous sheath sheath around the ascospores while Keissleriella italica lacks a sheath and their ascospore arrangement and the asci are also different from each other. Base pair differences of the LSU region of Keissleriella italica to K. dactylidicola and K. phragmiticola are $0.99 \%$ (6 bp out of 602 bp without gaps) and 1.3\% (8 bp out of 602 bp without gaps) respectively. Even though there is less support in our phylogenetic analyses, we rely mostly on its independent lineage, nucleotide and morphological differences to treat it as a new species.

\section{Pseudomurilentithecium Mapook \& K.D. Hyde}

Pseudomurilentithecium was introduced by Hyde et al. (2020) based on the combined LSU and ITS phylogeny. The genus clusters within Lentitheciaceae (Fig. 3). Pseudomurilentithecium shows close phylogenetic affinities to Poaceascoma and Setoseptoria (Hyde et al. 2020). However, Pseudomurilentithecium can be distinguished from Setoseptoria in having brown, fusiform and 
muriform ascospores whereas Poaceascoma has hyaline, filiform ascospores without vertical septa (Phookamsak et al. 2015). In this study, we introduce another species to the genus from Clematis vitalba.

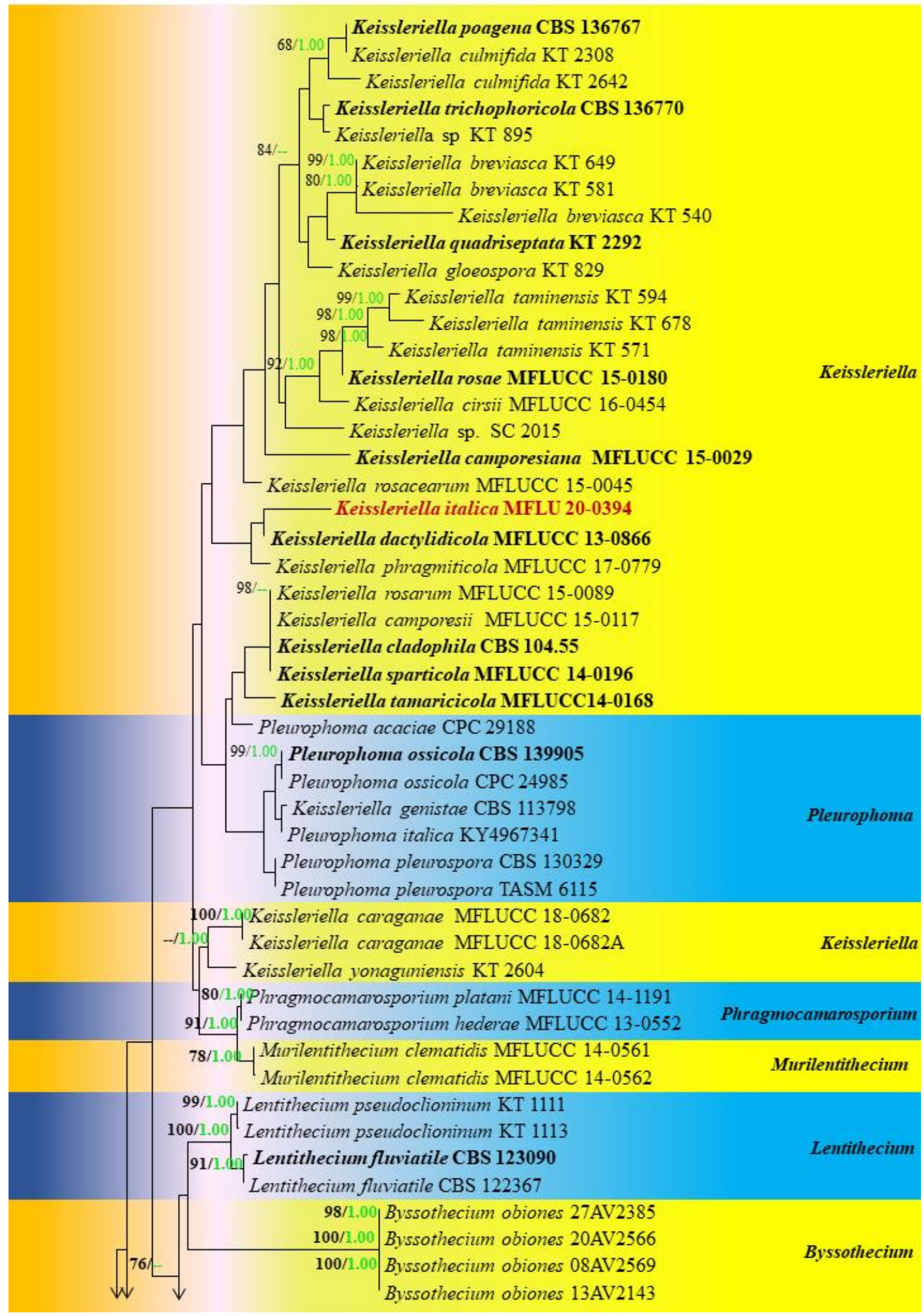

Figure 3 - Maximum likelihood analysis with 1000 bootstrap replicates yielded a best tree with the likelihood value of -12505.847030 . The combined LSU, SSU and ITS sequence datasets comprised 
69 strains with Massarina cisti (CBS 266.62) and M. pandanicola (MFLUCC 17-0596) as the outgroup taxa. The matrix had 542 distinct alignment patterns, with $25.87 \%$ of undetermined characters or gaps. Estimated base frequencies were as follows; $\mathrm{A}=0.244251, \mathrm{C}=0.220423, \mathrm{G}=$ $0.272920, \mathrm{~T}=0.262407$; substitution rates $\mathrm{AC}=1.276940, \mathrm{AG}=2.987661, \mathrm{AT}=1.881985, \mathrm{CG}=$ $0.507025, \mathrm{CT}=6.404577, \mathrm{GT}=1.000000$; gamma distribution shape parameter $\alpha=0.534298$. Maximum likelihood bootstrap (ML, black) values equal to or greater than $65 \%$ and Bayesian posterior probabilities (PP, green) equal to or greater than $0.95 \mathrm{PP}$ are given above the nodes. The scale bar indicates 0.03 changes. The ex-type strains are in black bold and new isolates are in red bold.

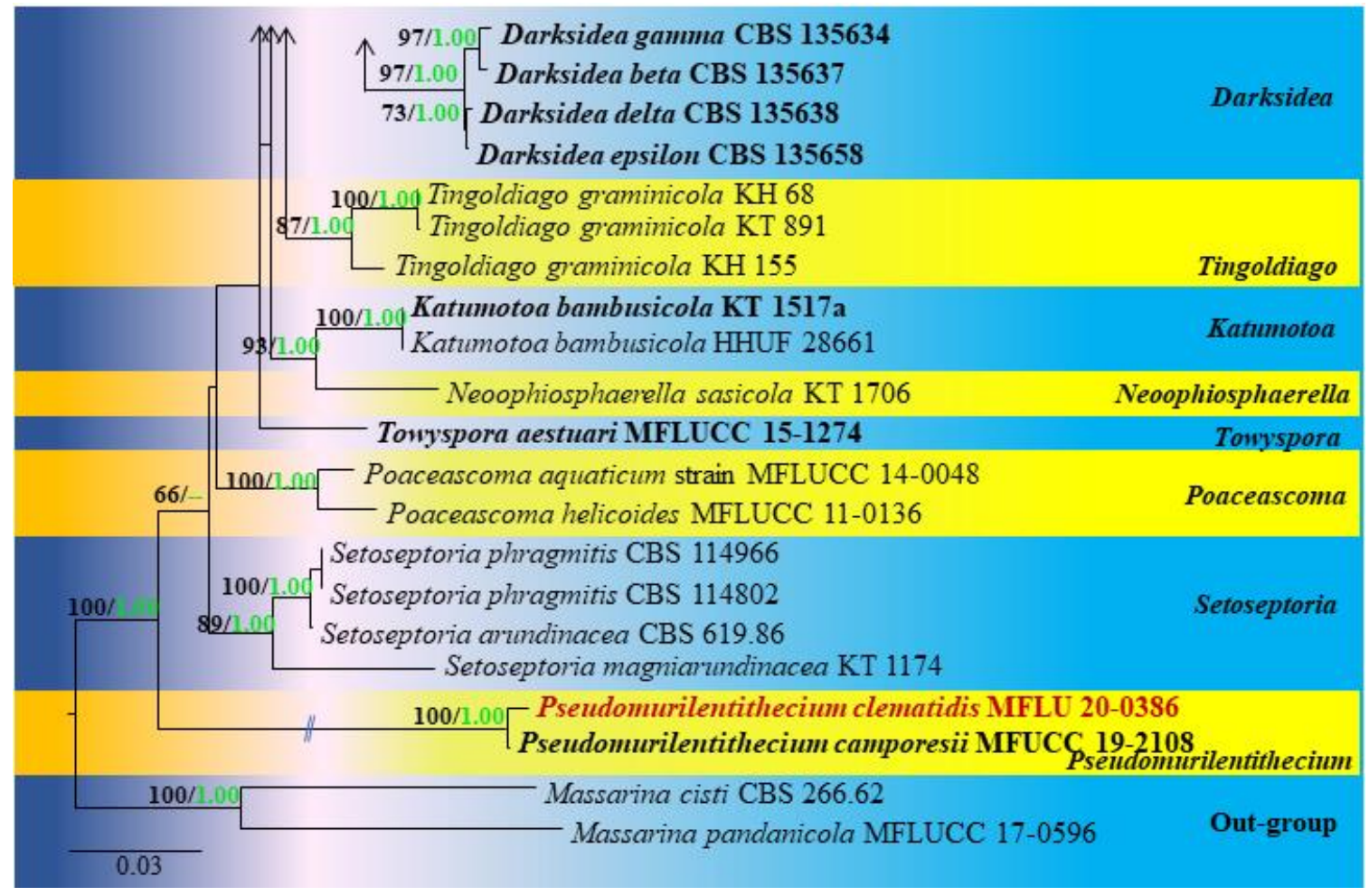

Figure 3 - Continued.

Pseudomurilentithecium clematidis Brahmanage, Camporesi \& K.D. Hyde, sp. nov.

Index Fungorum number: IF557595; Facesoffungi number: FOF 08007

Etymology - The species epithet refers to the host genus "Clematis".

Holotype - MFLU 20-0386

Saprobic on dead aerial branches of Clematis vitalba. Sexual morph: Ascomata 650-1500 $\mu \mathrm{m}$ high $\times 600-900 \mu \mathrm{m}$ diam., immersed, solitary, scattered, coriaceous, subglobose to globose, dark brown to black. Ostiolar neck protruding. Peridium 12-18 $\mu \mathrm{m}$ wide, composed of two layers, outer layer comprises 2-3 layers, dark brown cells of textura angularis and inner layer comprises hyaline cells of textura angularis. Hamathecium comprising 1.2-2 $\mu \mathrm{m}$ wide, cylindrical, septate, branched pseudoparaphyses. Asci 80-120 × 8-15 $\mu \mathrm{m}(\overline{\mathrm{x}}=102 \times 14 \mu \mathrm{m}, \mathrm{n}=10)$, bitunicate, 8-spored, cylindric-clavate, straight or slightly curved, apically rounded, short pedicellate. Ascospores 25-35 $\times 10-15 \mu \mathrm{m}(\overline{\mathrm{x}}=28 \times 12 \mu \mathrm{m}, \mathrm{n}=30)$, overlapping, uni-bi-seriate, initially hyaline to pale yellow, 1-septate when immature, becoming golden-brown to brown at maturity, ellipsoid to broadly fusiform, muriform, 3-8-transversely septate, with 1-2 vertical septa, constricted at the central septum, upper half wider than the lower half, straight or curved, surrounded by hyaline, thick gelatinous sheath. Asexual morph: Undetermined.

Material examined - ITALY, Province of Forlì-Cesena [FC], Fiumicello-Premilcuore, dead branches of Clematis vitalba (Ranunculaceae), 5 December 2013, E. Camporesi, IT 1559 (MFLU 20-0386, holotype; JZBH3490002, isotype). 
GenBank Accessions - LSU: MT370426; SSU: MT370370; ITS: MT370410
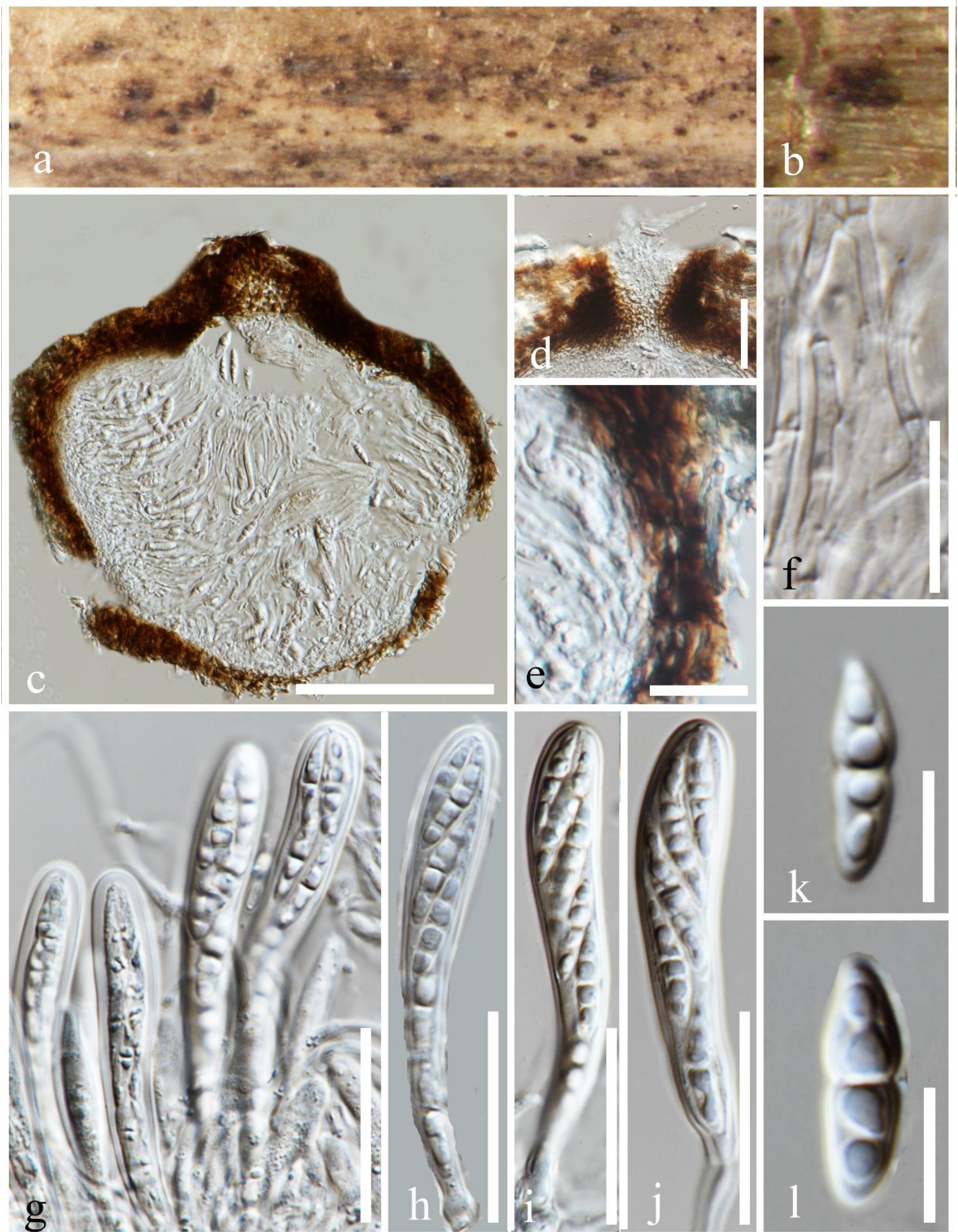

Figure 4 - Keissleriella italica (MFLU 20-0394, holotype). a Appearance of ascomata on host. b Close up of an ascoma. c Section through an ascoma. d Ostiolar region. e Peridium. f Pseudoparaphyses. g-j Asci. k, 1 Ascospores. Scale bars: $c=100 \mu \mathrm{m}, \mathrm{g}-\mathrm{j}=20 \mu \mathrm{m}, \mathrm{d}, \mathrm{e}, \mathrm{f}=10$ $\mu \mathrm{m}, \mathrm{k}, \mathrm{l}=5 \mu \mathrm{m}$. 


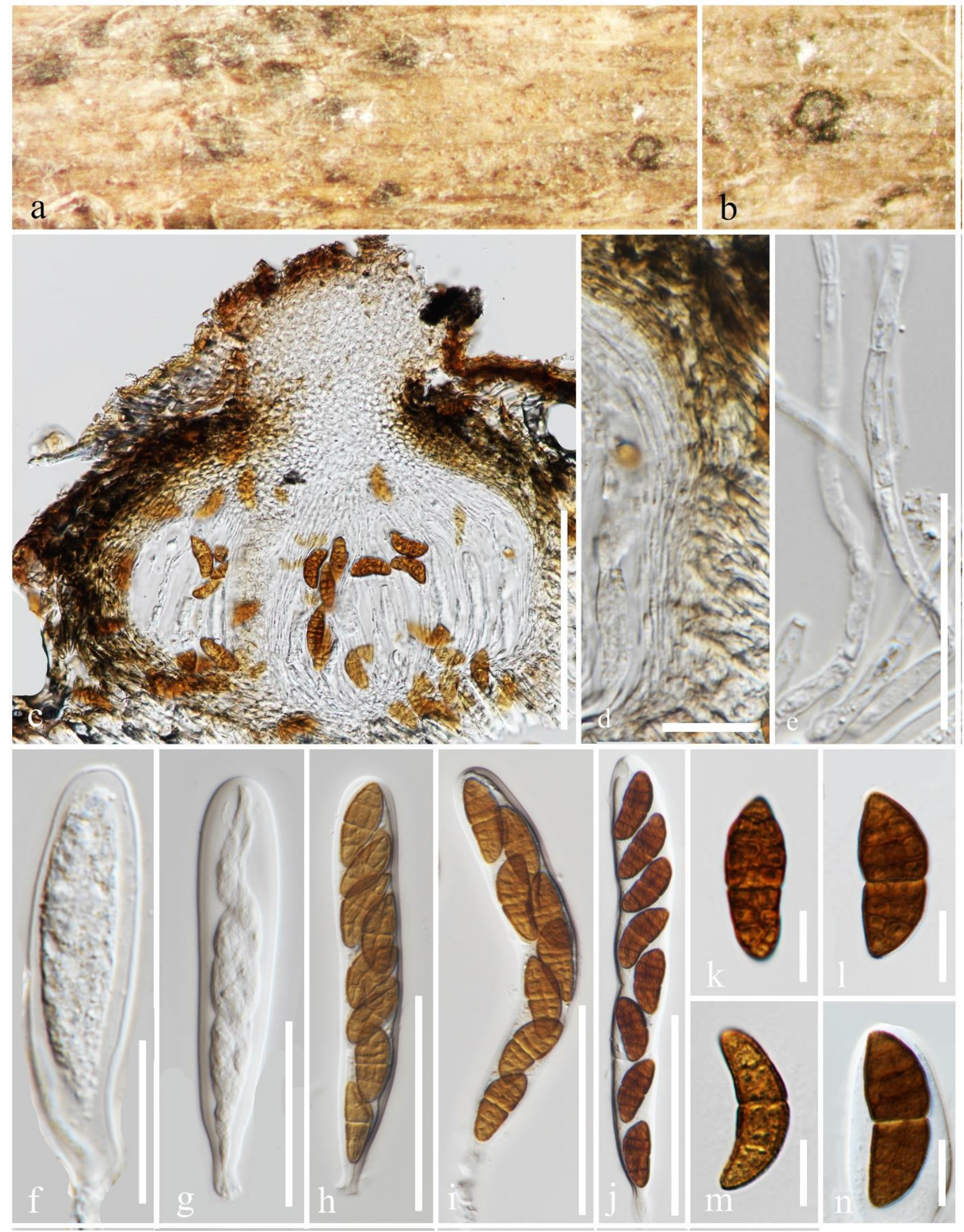

Figure 5 - Pseudomurilentithecium clematidis (MFLU 20-0386, holotype). a Appearance of ascomata on host. b Close up of an ascoma. c Section through an ascoma. d Peridium. e Pseudoparaphyses. f-i Asci. $\mathrm{j}-\mathrm{m}$ Ascospores n. Ascospore showing thick gelatinous sheath. Scale bars: $\mathrm{c}=500 \mu \mathrm{m}, \mathrm{f}-\mathrm{j}=50 \mu \mathrm{m}, \mathrm{e}=20 \mu \mathrm{m}, \mathrm{d}, \mathrm{k}-\mathrm{n}=10 \mu \mathrm{m}$

Notes - Pseudomurilentithecium clematidis shares similar features with $P$. camporesii in having ascomata with protruding ostiolar necks, cylindrical, septate, branched pseudoparaphyses, 
cylindric-clavate asci and ascospores that are initially hyaline to pale yellow which becomes golden-brown to brown at maturity and with a hyaline gelatinous sheath (Hyde et al. 2020). Pseudomurilentithecium clematidis has curved ascospores with a wider upper half than the lower half, while $P$. camporesii has mostly straight slightly curved ascospores with equal upper and lower portions. Size of ascomata $(650-1500 \times 600-900 \mu \mathrm{m} v s 130-145 \times 140-160 \mu \mathrm{m})$ and asci $(80-120$ $\times 8-15 \mu \mathrm{m} v s$ 90-115 $\times 16-22 \mu \mathrm{m})$ of $P$. clematidis and $P$. camporesii are also different. Based on a phylogenetic analysis of combined LSU and ITS sequence dataset, $P$. clematidis is related to $P$. camporesii (Fig. 3). However, base pair differences of the ITS region of $P$. clematidis and $P$. camporesii is $1.9 \%$ (11 bp out of 590 bp without gaps). Thus, $P$. clematidis is introduced as a novel species based on both morphology and DNA sequence data.

\section{Leptosphaeriaceae M.E. Barr}

Members of Leptosphaeriaceae are saprobes, hemibiotrophs or pathogens on stems and leaves of herbaceous or woody plants in terrestrial and aquatic habitats (Hyde et al. 2013, Ariyawansa et al. 2015b, Dayarathne et al. 2015, Jones et al. 2015, Liu et al. 2015, Wanasinghe et al. 2016, Tennakoon et al. 2017). Barr (1987) introduced Leptosphaeriaceae, and designated Leptosphaeria Ces. \& De Not. as the type of the family. Species in Leptosphaeriaceae are characterized by immersed, erumpent or superficial, perithecial ascomata with single papillate ostioles, fissitunicate, cylindrical asci and hyaline to brown, transversely septate ascospores (Hyde et al. 2013, Ariyawansa et al. 2015b, Phookamsak et al. 2019, Hongsanan et al. 2020). The asexual morphs of taxa in Leptosphaeriaceae are coelomycetes (Heterospora chenopodii (Westend.) Gruyter) or hyphomycetes (De Gruyter et al. 2013, Hyde et al. 2013, Wanasinghe et al. 2016, Tennakoon et al. 2017). Twelve genera are accepted in Leptosphaeriaceae (Wijayawardene et al. 2020, Hongsanan et al. 2020).

\section{Plenodomus Preuss}

Plenodomus was introduced by Preuss (1851) with $P$. rabenhorstii Preuss as the type species. However, $P$. rabenhorstii was replaced by P. lingam (Tode) Höhn. (sexual morph: Leptosphaeria maculans Ces. \& De Not.) by Boerema \& Kesteren (1964) due to the type material of $P$. rabenhorstii being lost during the World War II (Torres et al. 2005, Ariyawansa et al. 2015b, Phookamsak et al. 2019). The connection between L. maculans (sexual morph) and P. lingam (asexual morph) has been confirmed by single spore isolation (Boerema \& Kesteren 1964). We herein introduce two new host record of Plenodomus species in Italy.

Plenodomus biglobosus (Shoemaker \& H. Brun) Gruyter, Aveskamp \& Verkley

Fig. 7

Index Fungorum number: IF564727; Facesoffungi number: FoF08008

Saprobic on Alliaria petiolata. Sexual morph: Not observed. Asexual morph: Coelomycetous. Conidiomata 110-180 × 165-225 $\mu \mathrm{m}(\overline{\mathrm{x}}=150 \times 180 \mu \mathrm{m}, \mathrm{n}=5)$, pycnidial, solitary, scattered, erumpent, mostly subglobose, ostiolate. Ostiole papillate with a narrow pore. Pycnidial wall 20-30 $\mu \mathrm{m}$ wide, composed of several layers with thick-walled, brown to lightly pigmented cells of textura angularis. Conidiogenous cells $1-2.5 \times 1-1.2 \mu \mathrm{m}(\overline{\mathrm{x}}=2 \times 1 \mu \mathrm{m}, \mathrm{n}=20)$, phialidic, hyaline, smooth, ampulliform. Conidia $4-8 \times 1.5-2.5 \mu \mathrm{m}(\overline{\mathrm{x}}=6.2 \times 2 \mu \mathrm{m}, \mathrm{n}=30)$, hyaline, aseptate, ellipsoidal to subcylindrical, with two large guttules.

Material examined - ITALY, Province of Forlì-Cesena [FC], San Martino in Villafranca, on dead aerial stem of Alliaria petiolata (Brassicaceae), 12 February 2018, E. Camporesi, IT 3725 (MFLU 20-0393, JZBH3480002).

GenBank Accessions - LSU: MT370425; SSU: MT370369; ITS: MT370401

Notes - Our new isolate (MFLU 20-0393) comprises phialidic, hyaline, smooth, ampulliform conidiogenous cells and hyaline, aseptate, ellipsoidal to subcylindrical conidia. Our new isolate forms a well-supported lineage (96\% ML, 1.00 PP; Fig. 6) in a clade comprising P. biglobosus (Shoemaker \& H. Brun) Gruyter, Aveskamp \& Verkley, P. pimpinellae (Lowen \& Sivan.) Gruyter, 
Aveskamp \& Verkley, P. guttulatus Ariyaw. \& K.D. Hyde and P. hendersoniae (Fuckel) Gruyter, Aveskamp \& Verkley.

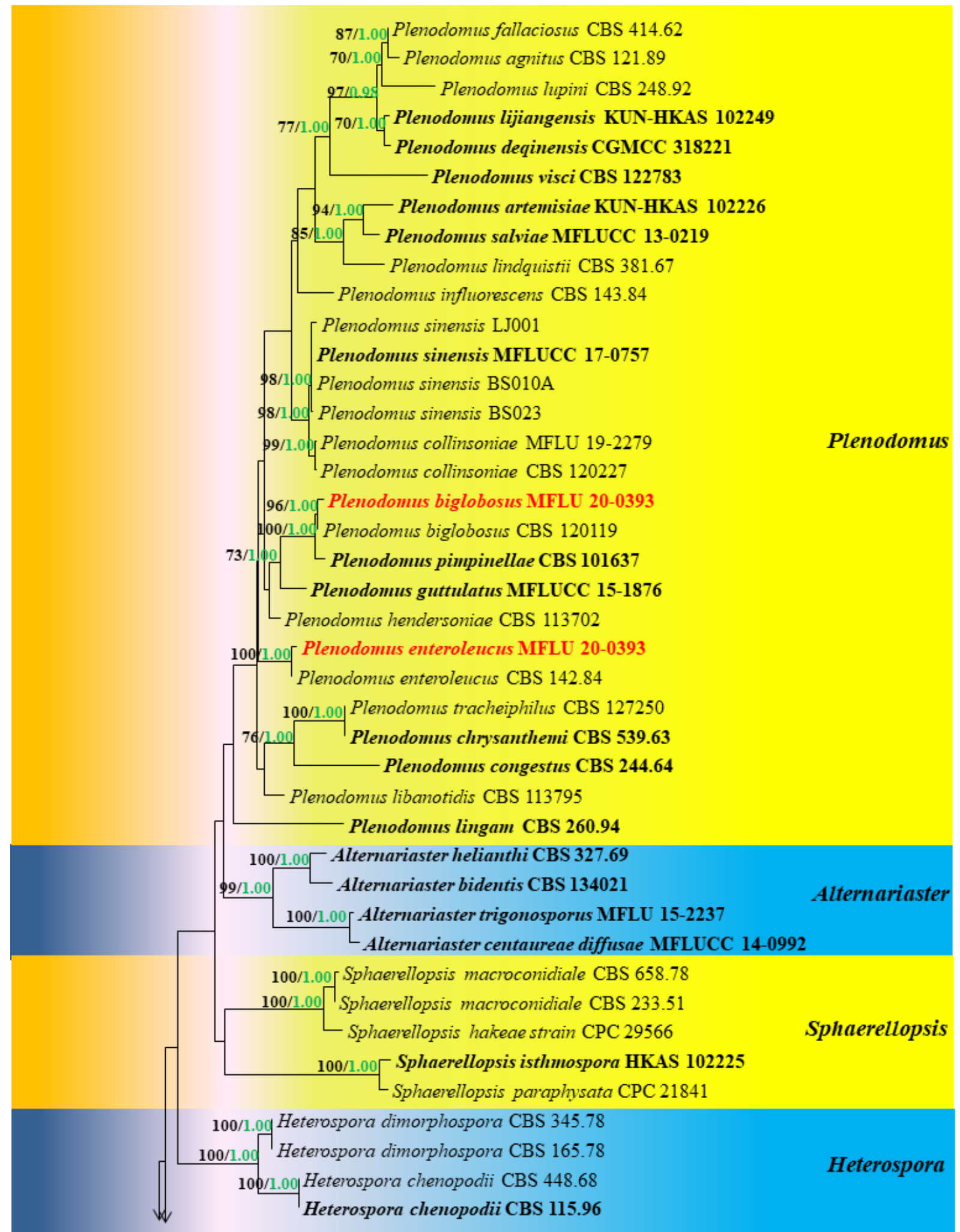

Figure 6 - Maximum likelihood analysis with 1000 bootstrap replicates yielded a best tree with the likelihood value of -12505.847030 . The combined LSU, SSU, ITS and TEF1 sequence dataset comprised 101 strains of Leptosphaeriaceae with Phaeosphaeria oryzae (CBS 110110), Phaeosphaeriopsis glaucopunctata (MFLUCC 13-0265) and Paraphoma radicina (CBS 111.79) as the outgroup taxa. Tree topology of the ML analysis was similar to the BI analysis. The matrix had 
542 distinct alignment patterns, with $25.87 \%$ of undetermined characters or gaps. Estimated base frequencies were as follows; $\mathrm{A}=0.244251, \mathrm{C}=0.220423, \mathrm{G}=0.272920, \mathrm{~T}=0.262407$; substitution rates $\mathrm{AC}=1.276940, \mathrm{AG}=2.987661, \mathrm{AT}=1.881985, \mathrm{CG}=0.507025, \mathrm{CT}=$ $6.404577, \mathrm{GT}=1.000000$; gamma distribution shape parameter $\alpha=0.534298$. Maximum likelihood bootstrap (ML, black) values equal to or greater than $65 \%$ and Bayesian posterior probabilities (PP, green) equal to or greater than $0.95 \mathrm{PP}$ are given above the nodes. The scale bar indicates 0.03 changes. The ex-type strains are in black bold and new isolates are in red bold.

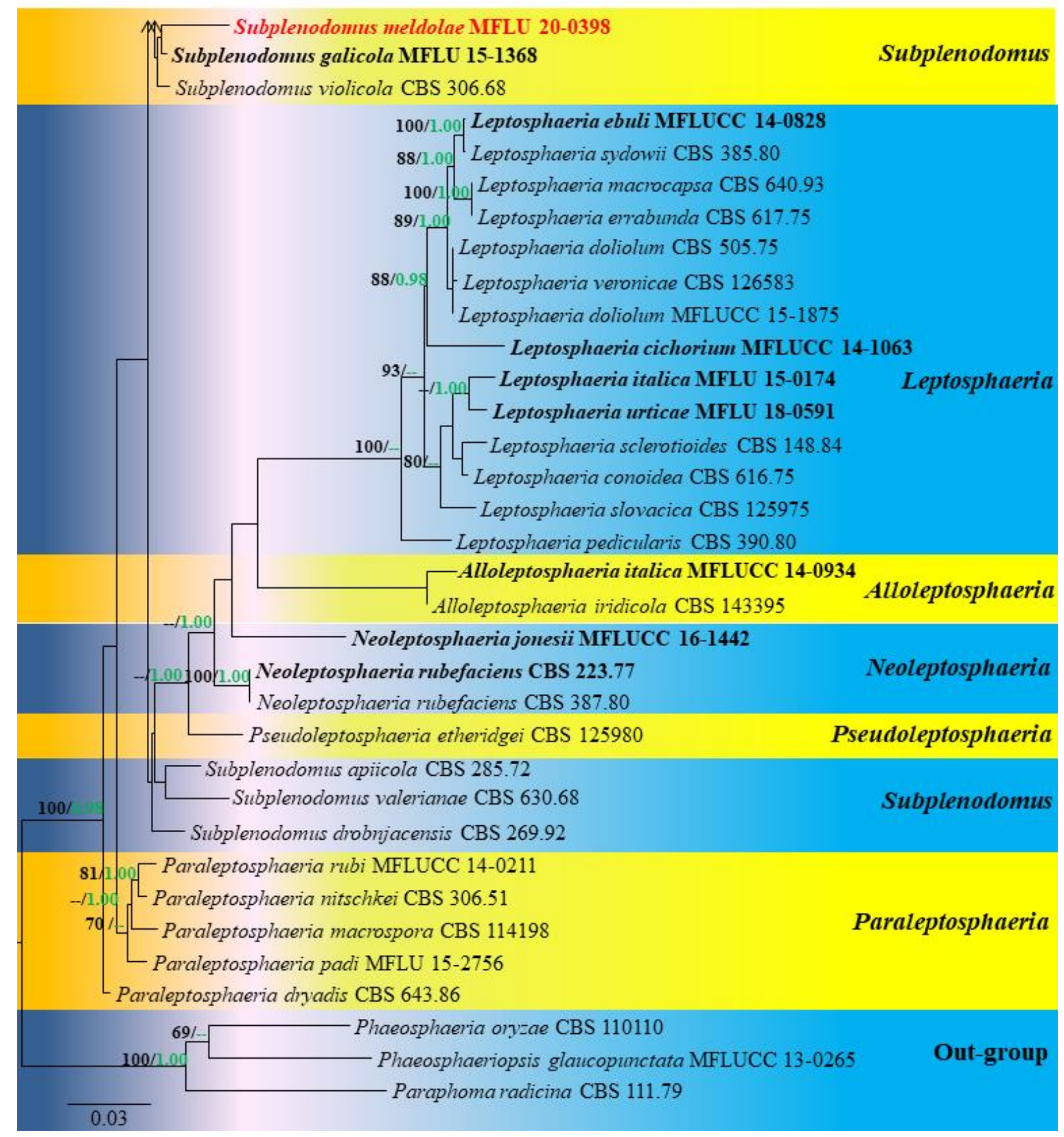

Figure 6 - Continued.

New isolate (MFLU 20-0393) shows a closer phylogenetic and morphological affinity to $P$. biglobosus (CBS 120119), which has been described from cultivated Brassica species as the cause of upper stem lesions. There are no significant differences in the base pair differences of LSU $(0.11 \%, 1 / 875)$ and ITS $(0.60 \%, 3 / 506]$ loci of our new isolate (MFLU 20-0393) and P. biglobosus (CBS 120119). Therefore, we identified our isolate (MFLU 20-0393) as P. biglobosus. This is the first record of P. biglobosus from Alliaria petiolata (Brassicaceae) in Italy. 

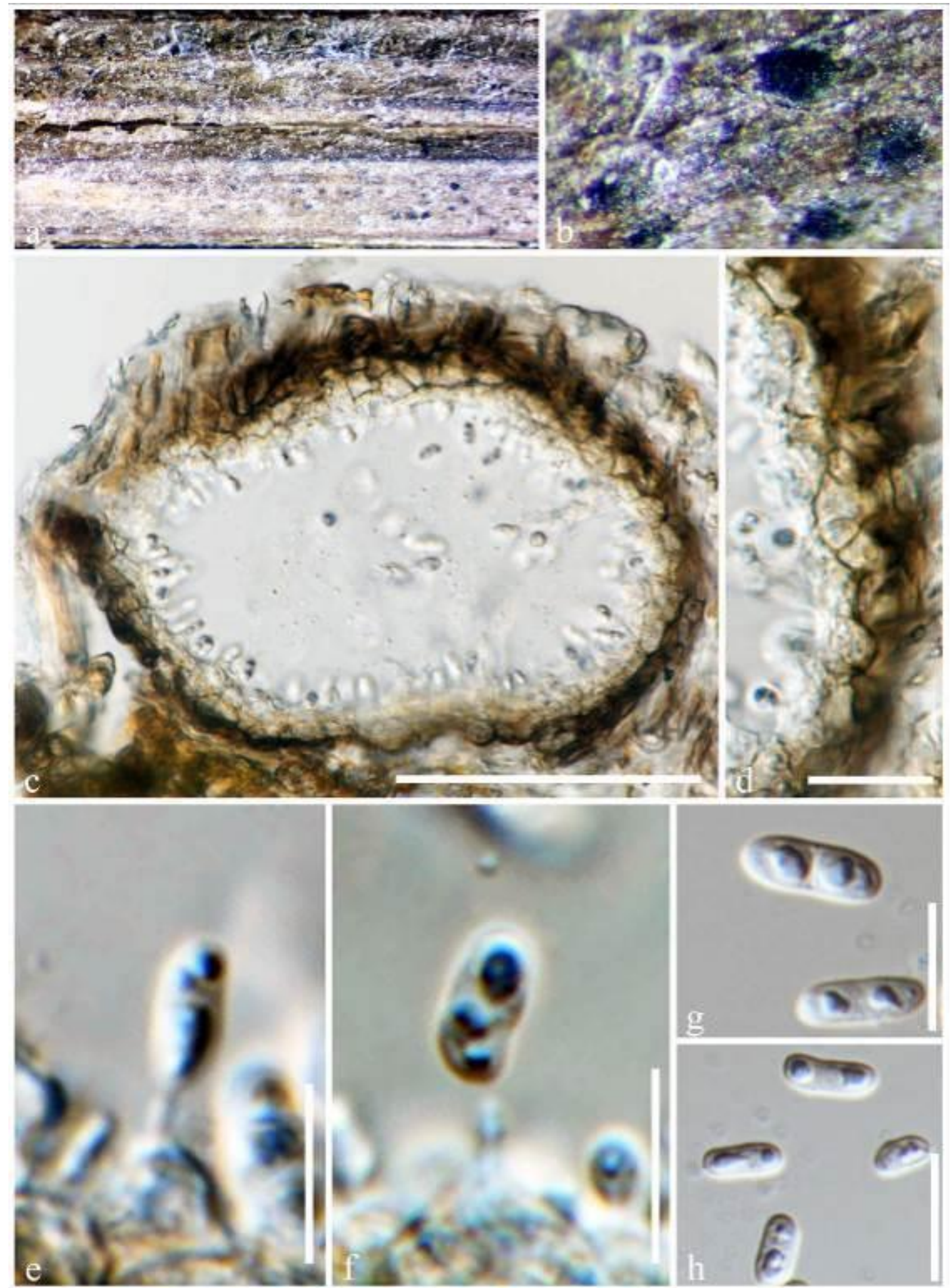

Figure 7 - Plenodomus biglobosus (MFLU 20-0393). a, b Conidiomata on host surface. c Vertical section through a conidioma. d Pycnidial wall. e, f Developing conidia. g, h Conidia. Scale bars: $\mathrm{c}=100 \mu \mathrm{m}, \mathrm{d}=20 \mu \mathrm{m}, \mathrm{g}, \mathrm{h}=10, \mathrm{e}, \mathrm{f}=5 \mu \mathrm{m}$.

Plenodomus enteroleucus (Sacc.) Gruyter, Aveskamp \& Verkley

Fig. 8

Index Fungorum number: IF564753; Facesoffungi number: FoF08009 
Saprobic on Picris hieracioides. Sexual morph: Undetermined. Asexual morph: Coelomycetous. Conidiomata 150-270 × 255-360 $\mu \mathrm{m}(\overline{\mathrm{x}}=200 \times 280 \mu \mathrm{m}, \mathrm{n}=5)$, pycnidial, solitary, scattered, erumpent, mostly subglobose, ostiolate. Ostiole slightly papillate with a narrow pore or opening via a rupture. Pycnidial wall 20-35 $\mu \mathrm{m}$ wide, composed of several layers with thick-walled, brown to lightly pigmented cells of textura angularis, surface heavily pigmented. Conidiogenous cells 1-2.5 $\mu \mathrm{m}$ long, holoblastic, phialidic, globose to oblong, individually hyaline and pale brown when in a mass, and formed from the inner layer of pycnidial wall. Conidia 5-8 $\times$ 1.5-2.8 $\mu \mathrm{m}(\overline{\mathrm{x}}=6.5 \times 2 \mu \mathrm{m}, \mathrm{n}=20)$, hyaline, aseptate, ellipsoidal to oblong, with guttules.

Material examined - ITALY, Province of Forlì-Cesena [FC], Saviana-Santa Sofia, on dead aerial stems of Picris hieracioides (Asteraceae), 8 November 2017, E. Camporesi, IT 3575a (MFLU 20-0389, JZBH3480001).

GenBank Accessions - LSU: MT370423, ITS: MT370399

Notes - Our new isolate (MFLU 20-0389) shows a closer phylogenetic affinity to $P$. enteroleucus (Fig. 6) and it morphologically resembles the holotype PAD, Gillet, 1878. However, MFLU 20-0389 has comparatively longer conidia (5-8 vs 3-4 $\mu \mathrm{m})$ than the type. There are no base pair differences in the ITS region of MFLU 20-0389 and CBS 142.84 strains. Therefore, by considering both phylogenetic and morphological data, we confirmed our new strain as $P$. enteroleucus. This is the first record of P. enteroleucus from Picris hieracioides (Asteraceae) in Italy.

\section{Subplenodomus Gruyter, Aveskamp \& Verkley}

De Gruyter et al. (2013) introduced Subplenodomus with S. violicola (P. Syd.) Gruyter, Aveskamp \& Verkley, as the type species, to accommodate selected phoma-like species that belong to Leptosphaeriaceae. Based on morphological and multi-gene phylogenetic analyses, Subplenodomus was accepted as an asexual morph of Leptosphaeriaceae (De Gruyter et al. 2013, Hyde et al. 2013, Ariyawansa et al. 2015b). Subplenodomus is characterized by thick-walled, ostiolate pycnidia, consisting of pseudoparenchymatous or sometimes scleroplectenchymatous cell types, phialidic, ampulliform to doliiform conidiogenous cells and hyaline, aseptate, and ellipsoid conidia (De Gruyter et al. 2013). Subplenodomus species formed two distant subclades in our phylogenetic analyses (Fig. 6). Subplenodomus sensu stricto comprises S. galicola, S. violicola and our new species, S. meldolae, while S. apiicola (Kleb.) Gruyter, Aveskamp \& Verkley, S. drobnjacensis (Bubák) Gruyter, Aveskamp \& Verkley and S. valerianae (Henn.) Gruyter, Aveskamp \& Verkley are grouped in Subplenodomus sensu lato. The genus comprises five species and here we introduce a new species from Italy.

Subplenodomus meldolanus Brahmanage \& K.D. Hyde, sp. nov.

Fig. 9

Index Fungorum number: IF557592; Facesoffungi number: FoF08010

Etymology - Epithet refers to the geographical region "Meldola" where the species was found.

Holotype - MFLU 20-0398

Saprobic on dead aerial stems of Medicago sp. (Fabaceae). Sexual morph: Ascomata 185$300 \times 260-420 \mu \mathrm{m}(\overline{\mathrm{x}}=240 \times 350 \mu \mathrm{m}, \mathrm{n}=5)$, immersed, slightly erumpent through the host tissues, globose to subglobose, dark brown, with a central ostiole. Peridium 12-18 $\mu \mathrm{m}$ wide, composed of 4-6 layers of brown to dark brown, thick-walled cells of textura angularis. Hamathecium composed on pseudoparaphyses, 0.8-1.5 $\mu \mathrm{m}$ diam., intermingled among asci, subcylindrical, smooth, hyphae-like. Asci $80-100 \times 12-13 \mu \mathrm{m}(\overline{\mathrm{x}}=92 \times 12.6 \mu \mathrm{m}, \mathrm{n}=20), 8$ spored, bitunicate, cylindrical to subcylindrical, subsessile to short pedicellate, with an indistinct ocular chamber. Ascospores 20-35 $\times 5-10 \mu \mathrm{m}(\overline{\mathrm{x}}=30 \times 8 \mu \mathrm{m}, \mathrm{n}=30)$, bi-seriate, partially overlapping, fusoid-ellipsoid, pale brown, finely roughened, 3-septate, slightly constricted at the septa, at times first cell above median septum becomes slightly swollen. Asexual morph: Undetermined. 

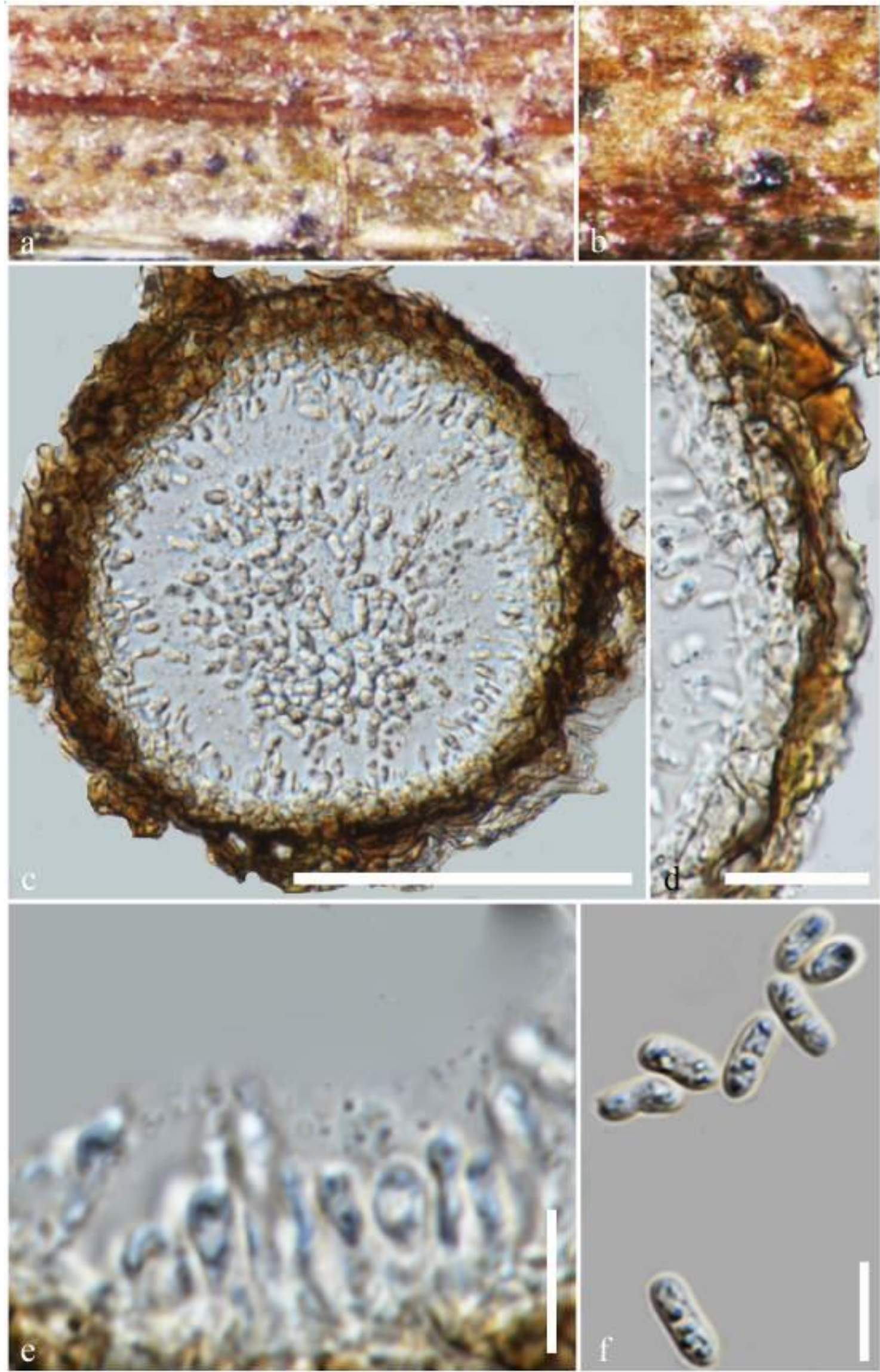

Figure 8 - Plenodomus enteroleucus (MFLU 20-0389). a, b Conidiomata on host surface. c Vertical section through a conidioma. d Pycnidial wall. e Developing conidia. $\mathrm{f}$ Conidia. Scale bars: $\mathrm{c}=50 \mu \mathrm{m}, \mathrm{d}=20 \mu \mathrm{m}, \mathrm{e}, \mathrm{f}=5 \mu \mathrm{m}$. 

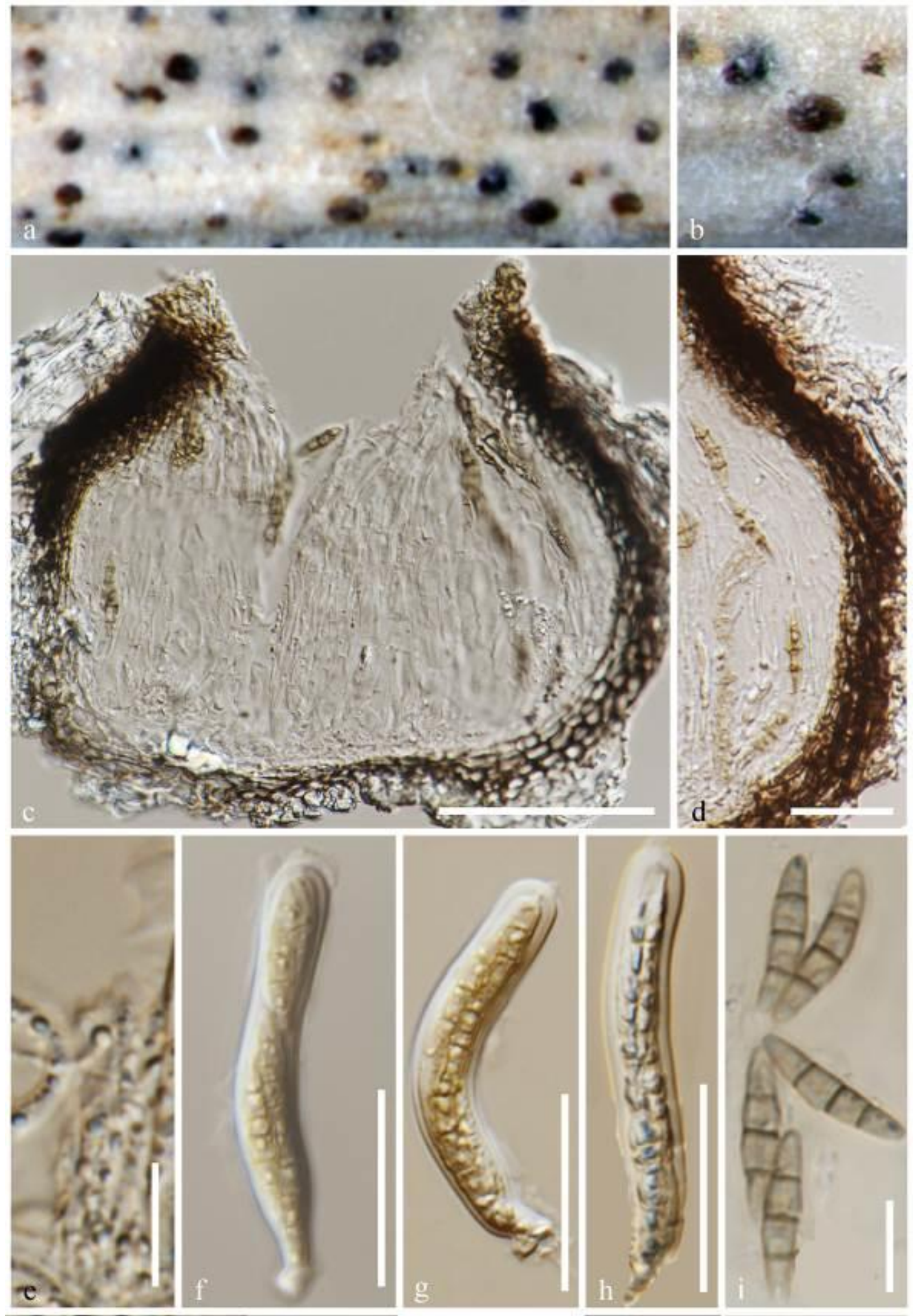

Figure 9 - Subplenodomus meldolanus (MFLU 20-0398, holotype). a Appearance of ascomata on host. b Close up of ascomata. c Section through an ascoma. d Peridium. e Pseudoparaphyses. $\mathrm{f}-\mathrm{h}$ Asci. i Ascospores. Scale bars: $\mathrm{c}=100 \mu \mathrm{m}, \mathrm{f}-\mathrm{h}=50 \mu \mathrm{m}, \mathrm{e}=20 \mu \mathrm{m}, \mathrm{d}, \mathrm{i}=10 \mu \mathrm{m}$. 
Material examined - ITALY, Province of Forlì-Cesena [FC], near Meldola, on a dead aerial stem of Medicago sp. (Fabaceae), 18 December 2017, E. Camporesi, IT 3625 (MFLU 20-0398, holotype; JZBH3480003 isotype).

GenBank Accessions - LSU: MT370424; ITS: MT370400

Notes - Phylogenetically, Subplenodomus meldolanus is closely related to S. galicola Phukhams., Tibpromma, Camporesi \& K.D. Hyde described from a dead stem of Galium sp. collected in Italy. Subplenodomus galicola has larger ascospores $(30-40 \times 6-9 \mu \mathrm{m})$ that are constricted only at the median septa and asci (66-120 × 12-17 $\mu \mathrm{m})$ (Tibpromma et al. 2017). Base pair differences of the ITS region of $S$. meldolanus as compared to $S$. galicola and $S$. violicola are $3.4 \%$ (30 bp out of $555 \mathrm{bp}$, without gaps) and 8.9\% (44 bp out of $490 \mathrm{bp}$, without gaps), respectively.

\section{Lophiostomataceae Luerss.}

Lophiostomataceae was erected by Saccardo (1883) with Lophiostoma macrostomum (Tode) Ces. \& De Not. as the type species (Hashimoto et al. 2018) and is characterized by slit-like ostiolar openings on a laterally compressed papilla, mostly clavate asci and 1 - to multi-septate and hyaline to dark brown ascospores with terminal appendages or mucilaginous sheaths (Hyde et al. 2013, Ariyawansa et al. 2015a, Liu et al. 2015, Thambugala et al. 2015, Hyde et al. 2017, Tibpromma et al. 2017). Members of some genera also have trabeculate pseudoparaphyses (Liew et al. 2000). There are 27 accepted genera viz. Crassiclypeus A. Hashim., K. Hiray. \& Kaz. Tanaka, Decaisnella Fabre, Dimorphiopsis Crous, Flabellascoma A. Hashim., K. Hiray. \& Kaz. Tanaka, Guttulispora Thambug., Qing Tian \& K.D. Hyde, Kiskunsagia D.G. Knapp, Imrefi \& Kovács, Lentistoma A. Hashim., K. Hiray. \& Kaz. Tanaka, Leptoparies A. Hashim., K. Hiray. \& Kaz. Tanaka, Lophiohelichrysum Dayar., Camporesi \& K.D. Hyde, Lophiopoacea Ariyaw., Thambug. \& K.D. Hyde, Lophiostoma Ces. \& De Not., Neotrematosphaeria Thambug., Kaz. Tanaka \& K.D. Hyde, Neovaginatispora A. Hashim., K. Hiray. \& Kaz. Tanaka, Parapaucispora A. Hashim., K. Hiray. \& Kaz. Tanaka, Paucispora Thambug., Kaz. Tanaka \& K.D. Hyde, Platystomum Trevis., Pseudocapulatispora Mapook \& K.D. Hyde, Pseudolophiostoma Thambug., Kaz. Tanaka \& K.D. Hyde, Pseudopaucispora A. Hashim., K. Hiray. \& Kaz. Tanaka, Pseudoplatystomum Thambug. \& K.D. Hyde, Sigarispora Thambug. \& K.D. Hyde, Tumularia Descals \& Marvanová and Vaginatispora K.D. Hyde (Hongsanan et al. 2020).

Pseudopaucispora A. Hashim., K. Hiray. \& Kaz. Tanaka

Pseudopaucispora was introduced to accommodate P. brunneospora A. Hashim., K. Hiray. \& Kaz. Tanaka, with pseudopycnidia and small, brown ascospores (Hashimoto et al. 2018). This genus is somewhat similar to Paucispora (Thambugala et al. 2015). Pseudopaucispora differs from Paucispora in having a single zone ascomatal peridium and an ascus with a short pedicel, whereas Paucispora has two zones in the peridium and an ascus with a relatively long pedicel (Thambugala et al. 2015, Hashimoto et al. 2018).

Pseudopaucispora hyalinospora Samarak. \& K.D. Hyde, sp. nov.

Fig. 11

Index Fungorum number: IF557374; Facesoffungi number: FoF08003

Etymology - Refers to its hyaline ascospores

Holotype - MFLU 18-0803

Saprobic on dead branches in terrestrial habitat. Sexual morph Ascomata 475-510 $\mu \mathrm{m}$ high, 350-400 $\mu \mathrm{m}$ diam. $(\overline{\mathrm{x}}=490 \times 375 \mu \mathrm{m}, \mathrm{n}=5)$, scattered, immersed, dark brown to black, globose to subglobose, ostiolate. Papilla 310-350 $\mu \mathrm{m}$ length, erumpent through host surface, coriaceous to carbonaceous. Ostiole crest-like, central, periphysate, broadly papillate, with an irregular pore-like opening, plugged by hyaline, filamentous hyphae. Peridium $30-60 \mu \mathrm{m}$ wide $(\overline{\mathrm{x}}=39.5 \mu \mathrm{m}, \mathrm{n}=20)$, single stratum, with 4-6 layers of dark brown to black cells of textura prismatica, fusing and indistinguishable from the host tissues. Hamathecium comprising 1.3-2 $\mu \mathrm{m}$ wide $(\overline{\mathrm{x}}=1.6 \mu \mathrm{m}, \mathrm{n}=$ 25), numerous, filamentous, septate, branched, trabeculate pseudoparaphyses, embedded in a 
gelatinous matrix. Asci 100-130 × 13-18 $\mu \mathrm{m}(\overline{\mathrm{x}}=110 \times 15.8 \mu \mathrm{m}, \mathrm{n}=25), 8$-spored, bitunicate, fissitunicate, cylindric-clavate, with a short pedicel, apically rounded, with an ocular chamber. Ascospores 33.5-38.5 $\times 7-8 \mu \mathrm{m}(\overline{\mathrm{x}}=38 \times 7.3 \mu \mathrm{m}, \mathrm{n}=30)$, L/W 5.2, uni- to bi-seriate, hyaline, light brown when mature, fusiform, 3-septate including 2 eusepta, constricted at the median septum, guttulate, smooth-walled, with a distinct narrow sheath at the end, $6-9 \mu \mathrm{m}$ long $(\overline{\mathrm{x}}=7.8$ $\mu \mathrm{m}, \mathrm{n}=15$ ). Asexual morph Undetermined.

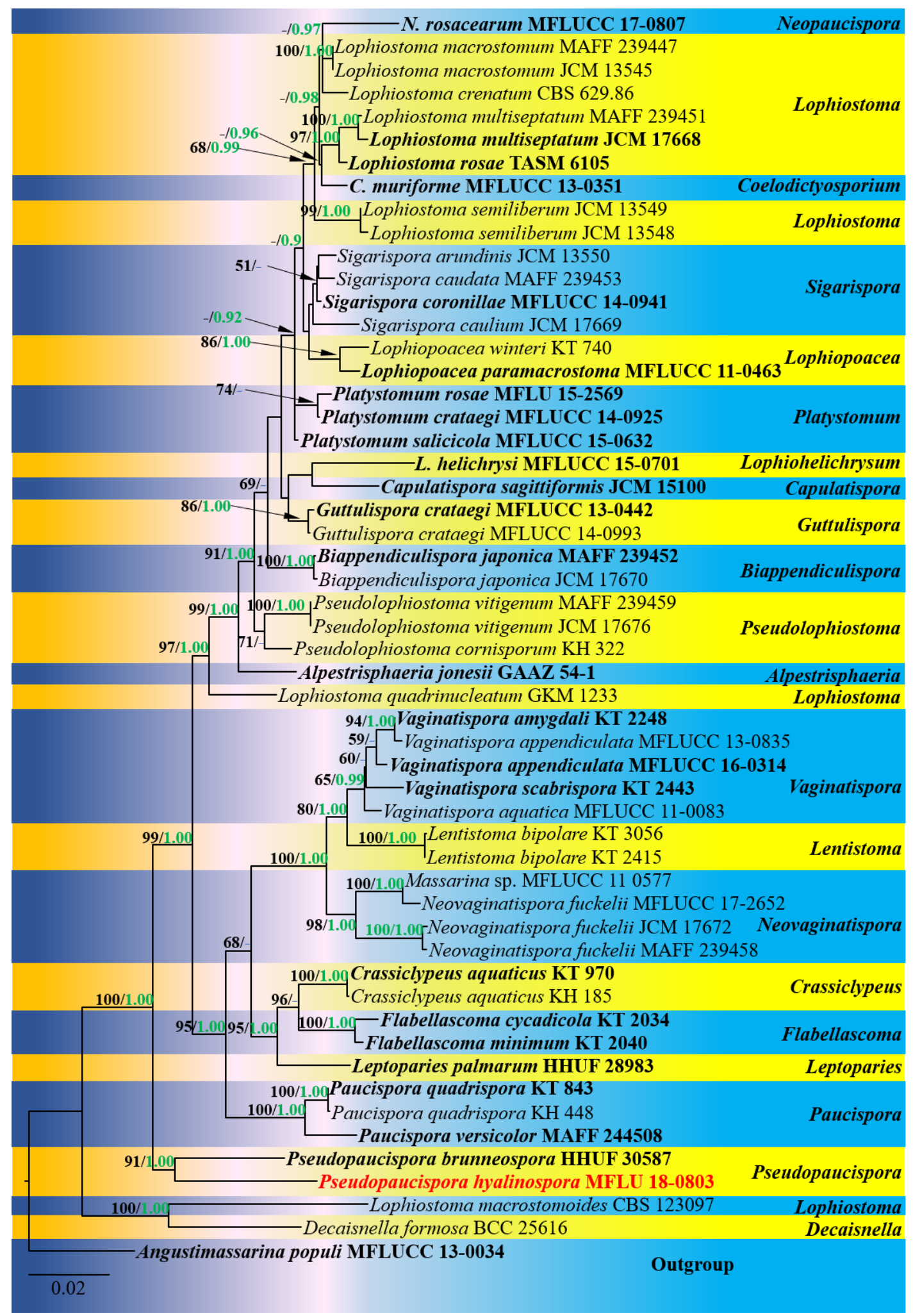

Figure 10 - Maximum likelihood analysis with 1000 bootstrap replicates yielded a best tree with the likelihood value of -12454.204760 . The combined LSU, SSU and TEF1 sequence dataset 
comprised 54 strains of Lophiostomataceae with Anguistimassarina populi (MFLUCC 13-0034) as the outgroup taxon. Tree topology of the ML analysis was similar to the BI analysis. The matrix had 709 distinct alignment patterns, with $9.91 \%$ of undetermined characters or gaps. Estimated base frequencies were as follows; $\mathrm{A}=0.246305, \mathrm{C}=0.242924, \mathrm{G}=0.273454, \mathrm{~T}=0.237317$; substitution rates $\mathrm{AC}=1.155343, \mathrm{AG}=3.247931, \mathrm{AT}=1.046007, \mathrm{CG}=1.482199, \mathrm{CT}=$ 9.600596, GT $=1.000000$; gamma distribution shape parameter $\alpha=0.652364$. Maximum likelihood bootstrap (ML, black) values equal to or greater than $50 \%$ and Bayesian posterior probabilities (PP, green) equal to or greater than $0.90 \mathrm{PP}$ are given above the nodes. The scale bar indicates 0.02 changes. The ex-type strains are in bold and new isolate is in red bold.

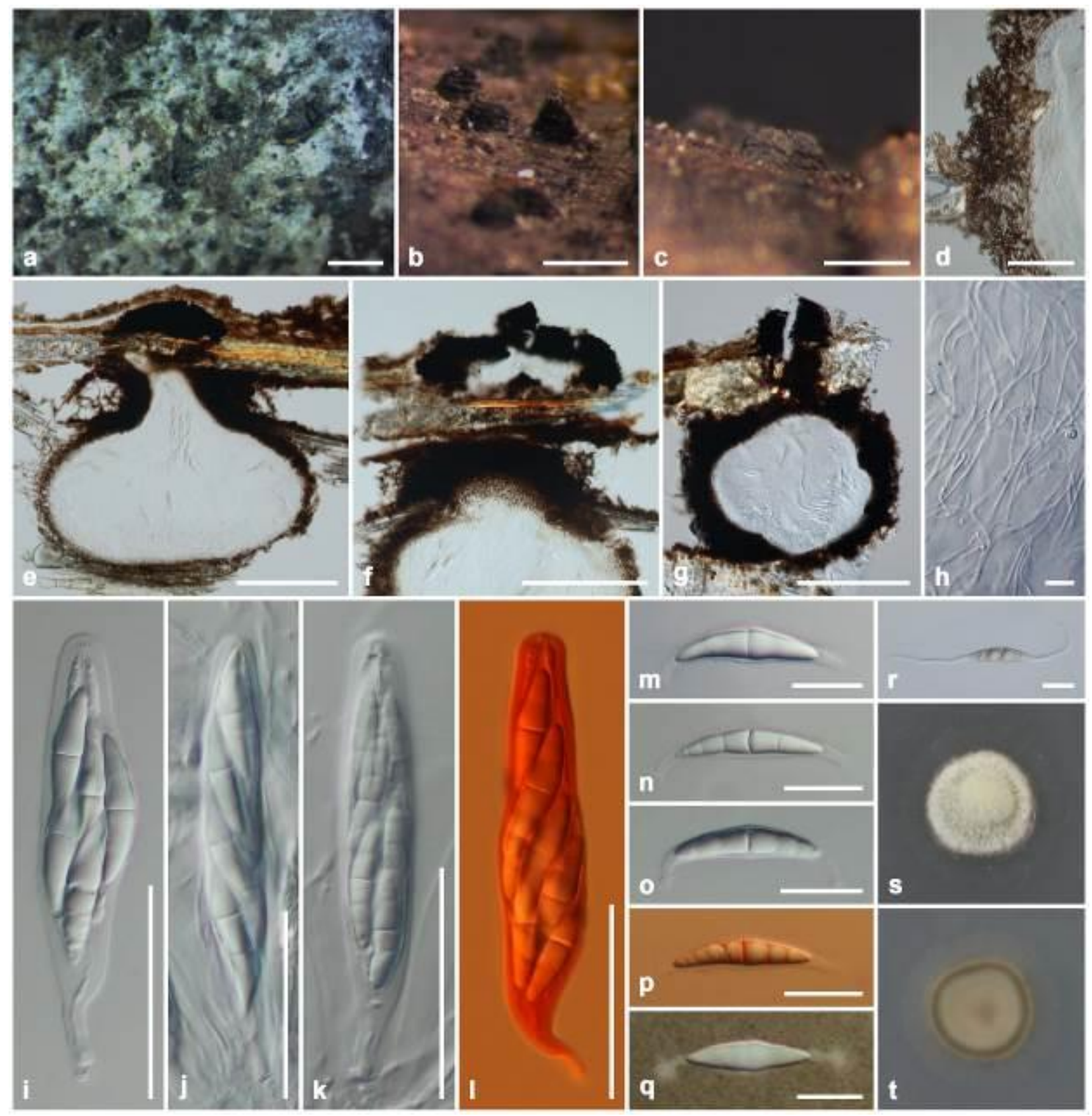

Figure 11 - Pseudopaucispora hyalinospora (MFLU 18-0803, holotype). a-c Ascomata on the substrate. $d$ Section of the peridium. e-g Cross sections of ascomata. h Pseudoparaphyses. $\mathrm{i}-1$ Asci ( 1 in congo red). $\mathrm{m}-\mathrm{q}$ Ascospores ( $\mathrm{p}$ in congo red, $\mathrm{q}$ in Indian ink). $\mathrm{r}$ Germinating ascospore. $\mathrm{s}$ Upper view of the colony. $\mathrm{t}$ Reverse view of the colony. Scale bars: $\mathrm{a}-\mathrm{c}=500 \mu \mathrm{m}, \mathrm{e}-\mathrm{g}=200 \mu \mathrm{m}$, $\mathrm{d}, \mathrm{i}-1=50 \mu \mathrm{m}, \mathrm{m}-\mathrm{r}=20 \mu \mathrm{m}, \mathrm{h}=10 \mu \mathrm{m}$. 
Culture characteristics - Ascospores becoming light brown and germinating on PDA within $18 \mathrm{~h}$ and producing germ tubes from the ends. Colonies on PDA reaching $16 \mathrm{~mm}$ diam. after 4 weeks at $25^{\circ} \mathrm{C}$, circular, filiform margin, effuse to raised, surface grey, reverse yellowish brown, dense, with greyish green edge.

Material examined - THAILAND, Chiang Rai Province, Mueang District, on dead branch, 28 July 2017, M.C. Samarakoon, SAMC026 (MFLU 18-0803, holotype; HKAS 102296 isotype), ex-type living culture, MFLUCC 18-0360.

GenBank Accessions - LSU: MT435501, SSU: MT435504, TEF1: MT729647

Notes - Pseudopaucispora hyalinospora (MFLU 18-0803) possesses scattered, immersed ascomata with an elongated and laterally compressed ostiole, a single-layered peridium composed of rectangular, brown cells, cylindrical to clavate asci and fusiform, 1-septate, smooth-walled ascospores with a narrow bipolar sheath at the end. Pseudopaucispora hyalinospora differs from $P$. brunneospora in having larger ascomata $(475-510 \mu \mathrm{m}$ high, 350-400 $\mu \mathrm{m}$ diam. vs 210-300 $\mu \mathrm{m}$ high, $215-355 \mu \mathrm{m}$ diam.), a thicker peridium (30-58 vs 15-18 $\mu \mathrm{m})$ and larger asci $(110 \times 15.8 v \mathrm{~s}$ $75.0 \times 8.7 \mu \mathrm{m})$ and ascospores $(38 \times 7.3 v s 15.3 \times 4.0 ; 1 / \mathrm{w} 5.2$ vs 3.8) (Hashimoto et al. 2018). Pseudopaucispora brunneospora is characterized by brown ascospores in contrast to the hyaline spores in P. hyalinospora (Hashimoto et al. 2018). Phylogenetic analysis of combined LSU, SSU and TEF1 sequence data revealed that $P$. hyalinospora strain MFLUCC 18-0360 clusters with $P$. brunneospora with high statistical support (91\% ML, 1.00 PP; Fig. 10). Hence, we introduce $P$. hyalinospora isolated from dead branches as a new species.

\section{Massarinaceae Munk}

Munk (1956) introduced Massarinaceae typified by Massarina Sacc. with M. eburnea (Tul. \& C. Tul.) Sacc. as the type species. Byssothecium Fuckel, Helminthosporiella Hern.-Restr., Sarria \& Crous, Helminthosporium Link, Massarina Sacc., Pseudodidymosphaeria Thambug. \& K.D. Hyde, Pseudosplanchnonema Chethana \& K.D. Hyde, Semifissispora H.J. Swart, Stagonospora (Sacc.) Sacc and Suttonomyces Wijayaw., Camporesi \& K.D. Hyde are accepted in Massarinaceae (Wijayawardene et al. 2020). In this study, we introduce a new species of Stagonospora.

Stagonospora (Sacc.) Sacc.

Stagonospora is typified by S. paludosa (Sacc. \& Speg.) Sacc., a species isolated from Carex pseudocyparus. Quaedvlieg et al. (2013) re-evaluated septoria-like genera and introduced Stagonospora sensu stricto in Massarinaceae due to pycnidial, immersed, globose, ostiolate conidiomata, conidiophores reduced to holoblastic conidiogenous cells with percurrent proliferations, and doliiform, cylindrical to ellipsoid, hyaline, guttulate conidia. Tanaka et al. (2015) revised Massarinaceae and accepted 12 species in Stagonospora based on both morphology and phylogeny data.

Stagonospora poaceicola Tennakoon, Phookamsak R \& K.D. Hyde, sp. nov.

Fig. 13

Index Fungorum number: IF557371; Facesoffungi number: FoF07748;

Etymology - Name reflects the host family (Poaceae) of the new species.

Holotype - MFLU 17-0769

Saprobic on dead stems of grasses. Sexual morph: Ascomata 170-220 × 160-190 $\mu \mathrm{m}$ diam. $(\overline{\mathrm{x}}=197 \times 177 \mu \mathrm{m}, \mathrm{n}=8)$, solitary or aggregated, semi-immersed to erumpent, elongate, uniloculate, subglobose or obpyriform, coriaceous, black, ostiolate. Peridium 20-25 $\mu \mathrm{m}$ wide composed of 3-4 layers of thin-walled, lightly pigmented to dark brown, somewhat flattened cells of textura angularis. Hamathecium composed of dense, $1.8-2.5 \mu \mathrm{m}$ wide, filamentous, distinctly septate, broad, cellular pseudoparaphyses, slightly constricted at the septum, anastomosing at the apex, embedded in a hyaline gelatinous matrix. Asci $(65-) 70-110(-115) \times(12-) 14-21(-23) \mu \mathrm{m}(\overline{\mathrm{x}}$ $=89 \times 17 \mu \mathrm{m}, \mathrm{n}=35), 8$-spored, bitunicate, fissitunicate, clavate, short pedicellate $(7-17.5 \mu \mathrm{m}$ long), apically rounded with a shallow ocular chamber. Ascospores $21-28(-30) \times 4.5-6.5 \mu \mathrm{m}(\overline{\mathrm{x}}=$ $24.4 \times 5.5 \mu \mathrm{m}, \mathrm{n}=35$ ), overlapping, uniseriate to biseriate or triseriate, hyaline, narrowly fusiform, 
2-3-septate, slightly constricted at the middle septum, straight to curved, with or without guttules, smooth-walled, without a sheath. Asexual morph: Undetermined.

Material examined - CHINA, Yunnan Province, Xishuangbanna, Nabanhe, on dead stems of grass sp. (Poaceae), 25 November 2015, D.S. Tennakoon, KIB 029 (MFLU 17-0769, holotype; KUN-HKAS 96342, isotype).

GenBank Accessions - ITS: MT199603, LSU: MT199604, SSU: MT199602, TEF1: MT199325.

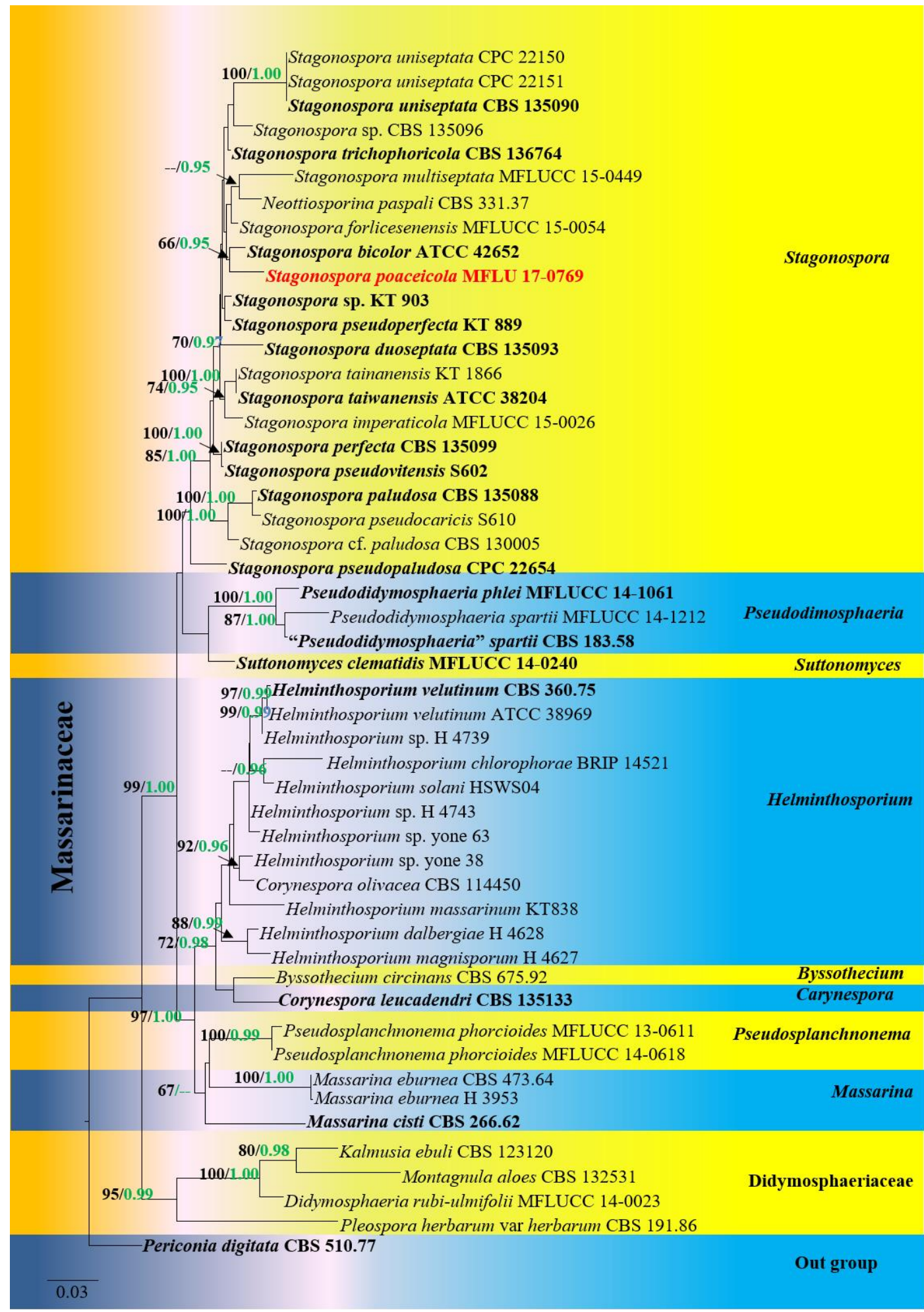

Figure 12 - Maximum likelihood analysis with 1000 bootstrap replicates yielded a best tree with the likelihood value of -14639.631854 . The combined LSU, SSU, ITS and TEF1 sequence dataset 
comprised 50 strains with Periconia digitata (CBS 510.77) as the outgroup taxon. Tree topology of the ML analysis was similar to the BI. The matrix had 898 distinct alignment patterns, with 39.41 $\%$ of undetermined characters or gaps. Estimated base frequencies were as follows; $A=0.239744$, $\mathrm{C}=0.237635, \mathrm{G}=0.270639, \mathrm{~T}=0.251148$; substitution rates $\mathrm{AC}=1.597454, \mathrm{AG}=2.732638, \mathrm{AT}$ $=1.893531, \mathrm{CG}=1.067351, \mathrm{CT}=8.759818, \mathrm{GT}=1.000000$; gamma distribution shape parameter $\alpha=0.486600$. Maximum likelihood bootstrap (ML, black) values equal to or greater than $60 \%$ and Bayesian posterior probabilities (PP, green) equal to or greater than $0.90 \%$ are given above the nodes. The scale bar indicates 0.03 changes. The ex-type strains are in black bold and new isolates are in red bold.
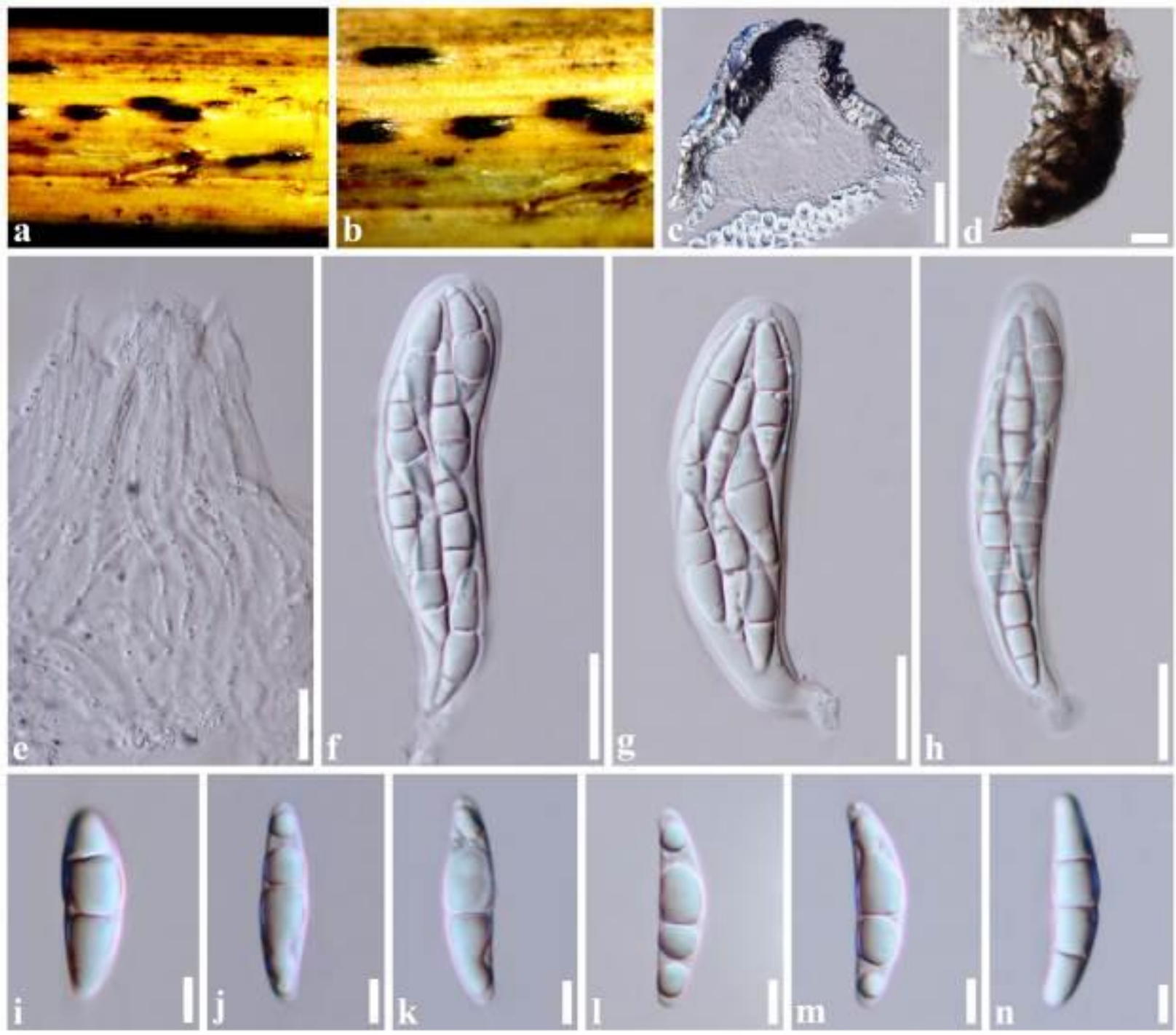

Figure 13 - Stagonospora poaceicola (MFLU 17-0769, holotype). a Appearance of ascomata on host. b Close-up of ascomata. c Section of an ascoma. $d$ Section of peridium. e Pseudoparaphyses. $\mathrm{f}-\mathrm{h}$ Asci. $\mathrm{i}-\mathrm{n}$ Ascospores. Scale bars: $\mathrm{c}=50 \mu \mathrm{m}, \mathrm{d}=10 \mu \mathrm{m}, \mathrm{e}-\mathrm{h}=20 \mu \mathrm{m}$, $\mathrm{i}-\mathrm{n}=5 \mu \mathrm{m}$.

Notes - Stagonospora poaceicola shares similar morphological characteristics to S. perfecta Quaedvl., Verkley \& Crous and S. pseudoperfecta Kaz. Tanaka \& K. Hiray. in having short pedicellate asci and hyaline, fusiform, straight to curved ascospores. However, S. perfecta and $S$. pseudoperfecta differs from $S$. poaceicola by having ascospores with clear sub-median septum surrounded by a mucilaginous sheath (Tanaka et al. 2015). Furthermore, S. poaceicola has semiimmersed to erumpent ascomata, whereas $S$. perfecta and $S$. pseudoperfecta have immersed 
ascomata. According to the combined multi-gene phylogeny (LSU, SSU, ITS and TEF1), $S$. poaceicola grouped with other Stagonospora species and shows a closer affinity to S. bicolor (Fig. 12). However, S. bicolor (D. Hawksw., W.J. Kaiser \& Ndimande) Kaz. Tanaka \& K. Hiray. can be distinguished from $S$. poaceicola by having melanized ascospores. These ascospores appeared to be released in a hyaline or very pale brown stage with 1-3 septa, but later the upper central cell in the 3 -septate spores slightly inflated and can become dark brown to almost black at maturity (Eriksson \& Hawksworth 2003).

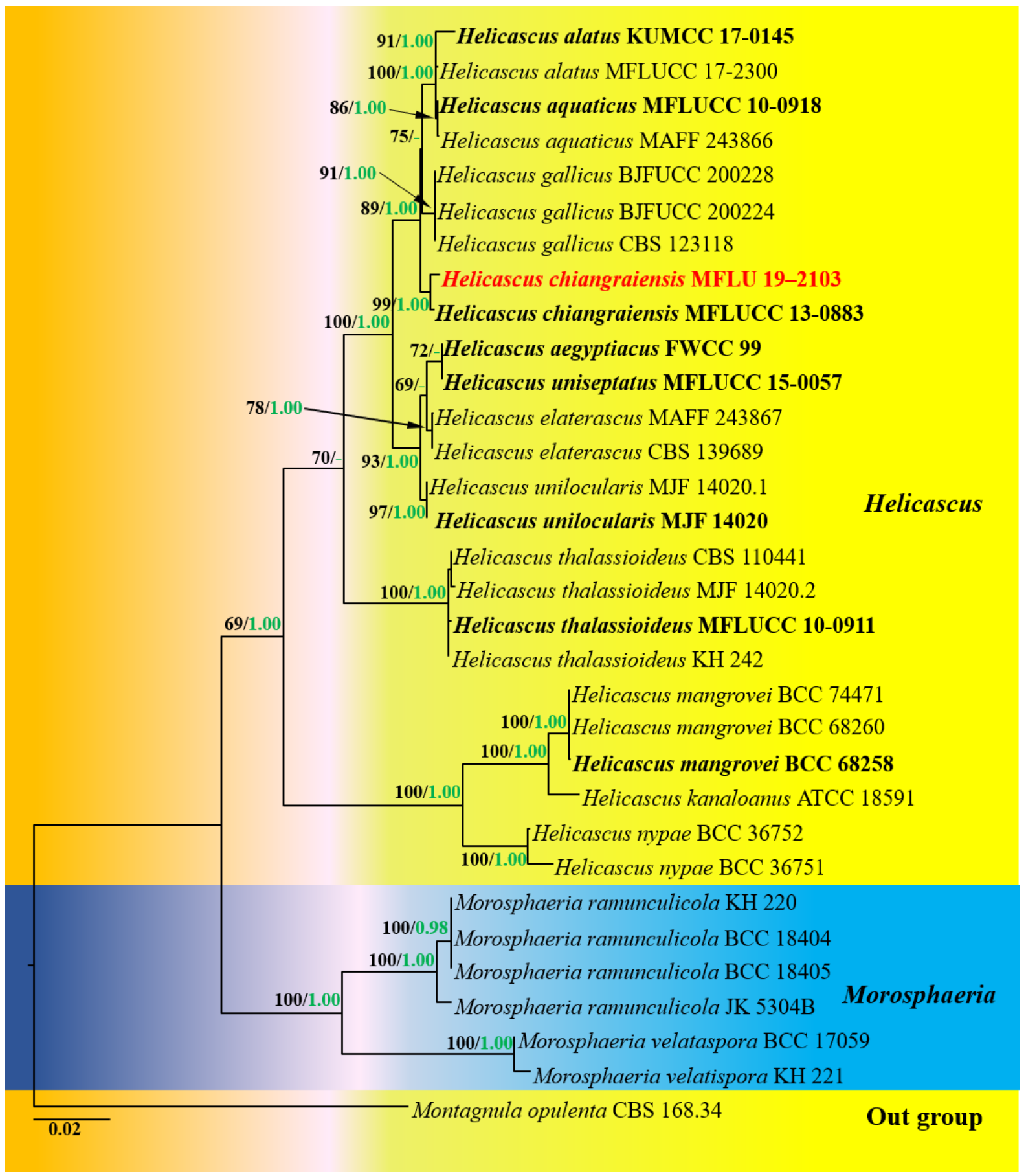

Figure 14 - Maximum likelihood analysis with 1000 bootstrap replicates yielded a best tree with the likelihood value of -14639.631854 . The combined LSU, SSU, ITS and TEF1 sequence dataset comprised 32 strains with Montagnula opulenta (CBS 168.34) as the outgroup taxon. Tree topology of the ML analysis was similar to the BI analysis. The matrix had 898 distinct alignment patterns, with $39.41 \%$ of undetermined characters or gaps. Estimated base frequencies were as follows; $\mathrm{A}=0.250353, \mathrm{C}=0.237635, \mathrm{G}=0.270639, \mathrm{~T}=0.251148$; substitution rates $\mathrm{AC}=$ 
1.597454, $\mathrm{AG}=2.732638, \mathrm{AT}=1.893531, \mathrm{CG}=1.067351, \mathrm{CT}=8.759818, \mathrm{GT}=1.000000$; gamma distribution shape parameter $\alpha=0.486600$. Maximum likelihood bootstrap (ML, black) values equal to or greater than $65 \%$ and Bayesian posterior probabilities (PP, green) equal to or greater than $0.95 \mathrm{PP}$ are given above the nodes. The scale bar indicates 0.02 changes. The ex-type strains are in black bold and new isolate is in red bold.

\section{Morosphaeriaceae Suetrong et al.}

Morosphaeriaceae was introduced by Suetrong et al. (2009) in Pleosporales to accommodate Massarina ramunculicola K.D. Hyde and M. velatispora K.D. Hyde \& Borse, which did not group in Massarinaceae in their phylogenetic analyses. Morosphaeriaceae includes four genera, namely: Aquilomyces D.G. Knapp, Kovács, J.Z. Groenew. \& Crous, Clypeoloculus Kaz. Tanaka \& K. Hiray., Helicascus Kohlm. and Morosphaeria Suetrong et al. (Jones et al. 2015, 2019, Wijayawardene et al. 2017).

\section{Helicascus Kohlm.}

Helicascus was established by Kohlmeyer (1969) and is typified by H. kanaloanus Kohlm. (Kohlmeyer 1969). This genus includes 11 species (Wijayawardene et al. 2017, 2018, Zeng et al. 2018). Helicascus is characterized by immersed ascostromata comprising several locules that share a common periphysate ostiole lying under a more or less conspicuous pseudostromatic tissue or solitary to clustered unilocular ascostromata, which may be immersed to almost superficial and septate ascospores with or without a mucilaginous sheath (Kohlmeyer 1969). Helicascus species have been reported from Australia, Brunei, Chile, China, Egypt, France, Philippines, South Africa, Thailand and the USA associated with freshwater habitats (Kohlmeyer 1969, Hyde 1991, Hyde et al. 1998, Cai et al. 2002, 2003, Zhang et al. 2013, 2014, Luo et al. 2016, Preedanon et al. 2017).

Helicascus chiangraiensis Z.L. Luo, J.K Liu, H.Y. Su \& K.D. Hyde

Fig. 15

Index Fungorum number: IF552003; Facesoffungi number: FoF02019

Saprobic on dead wood, submerged in freshwater. Sexual morph: Ascomata 200-290 $\mu \mathrm{m}$ diam, $250-400 \mu \mathrm{m}$ high $(\overline{\mathrm{x}}=250 \times 325 \mu \mathrm{m}, \mathrm{n}=5)$, solitary, scattered, black, immersed, unilocular, globose to subglobose, ostiolate. Peridium 34-52 $\mu \mathrm{m}$, subhyaline to dark brown, composed of several layers of pseudoparenchymatous cells, outer layer dark brown, with thick-walled cells, arranged in a textura angularis, inner layer hyaline with flattened, thin-walled cells. Hamathecium composed of 1.8-2.4 $\mu \mathrm{m}(\overline{\mathrm{x}}=2.1 \mu \mathrm{m}, \mathrm{n}=20)$ wide, septate, hypha-like pseudoparaphyses, slightly constricted at the septa, embedded in a gelatinous matrix. Asci $78-110 \times 13-20 \mu \mathrm{m}(\overline{\mathrm{x}}=93.5 \times 16.9$ $\mu \mathrm{m}, \mathrm{n}=20$ ), 8 -spored, bitunicate, fissitunicate, clavate, apically rounded, dehiscent, endoascus narrow, coiled within ectoascus, ectoascus forming a long tail-like extension. Ascospores $19.5-32 \times$ 5.5-8.7 $\mu \mathrm{m}(\overline{\mathrm{x}}=26.6 \times 7.5 \mu \mathrm{m}, \mathrm{n}=20)$, uni to bi-seriate and partially overlapping, ellipsoidfusiform, verruculose, upper end narrowly rounded, lower end tapering, slightly curved in side view, with 2-4 large refractive guttules, 1-euseptate, septum submedian, hyaline when young, becoming brown when mature, thick-walled, verruculose, slightly constricted at the septum, surrounded by a $2.9-5.2 \mu \mathrm{m}(\bar{x}=4.1 \mu \mathrm{m}, \mathrm{n}=10)$ wide sheath. Asexual morph: Undetermined.

Culture characteristics - Ascospores becoming blackish brown and germinating on PDA within $15 \mathrm{~h}$. Colonies on PDA reaching $13-15 \mathrm{~mm}$ diam. after one week at $25^{\circ} \mathrm{C}$, circular, undulate margin, smooth and effuse surface, yellowish white, reverse yellowish brown.

Material examined - CHINA, Guizhou Province, Guiyang City, Tongxin, Yan Lou, on dead wood submerged in an inland tank, 17 June 2018, M.C. Samarakoon, SAMC160 (MFLU 19-2103; HKAS 102391), living culture MFLUCC 20-0092.

GenBank Accessions - ITS: MT425059; LSU: MT435500, SSU: MT435503, TEF1: MT462701

Notes - Helicascus chiangraiensis was introduced by Luo et al. (2016) on decaying wood submerged in a pond from northern Thailand. The species is characterized by unilocular ascomata, coiling asci and verruculose ascospores with a mucilaginous sheath. The specimen in this study 
(MFLU 19-2103) is similar to H. chiangraiensis. In addition, the molecular analysis showed that our strain clusters with $H$. chiangraiensis with high statistical support (99\% ML, 1.00 PP; Fig. 14). The base pairs comparisons of LSU and TEF1 sequences also show $100 \%$ similarity among MFLU 15-0084 and MFLU 19-2103. Our isolate (MFLU 19-2103) is the first record of H. chiangraiensis from China.

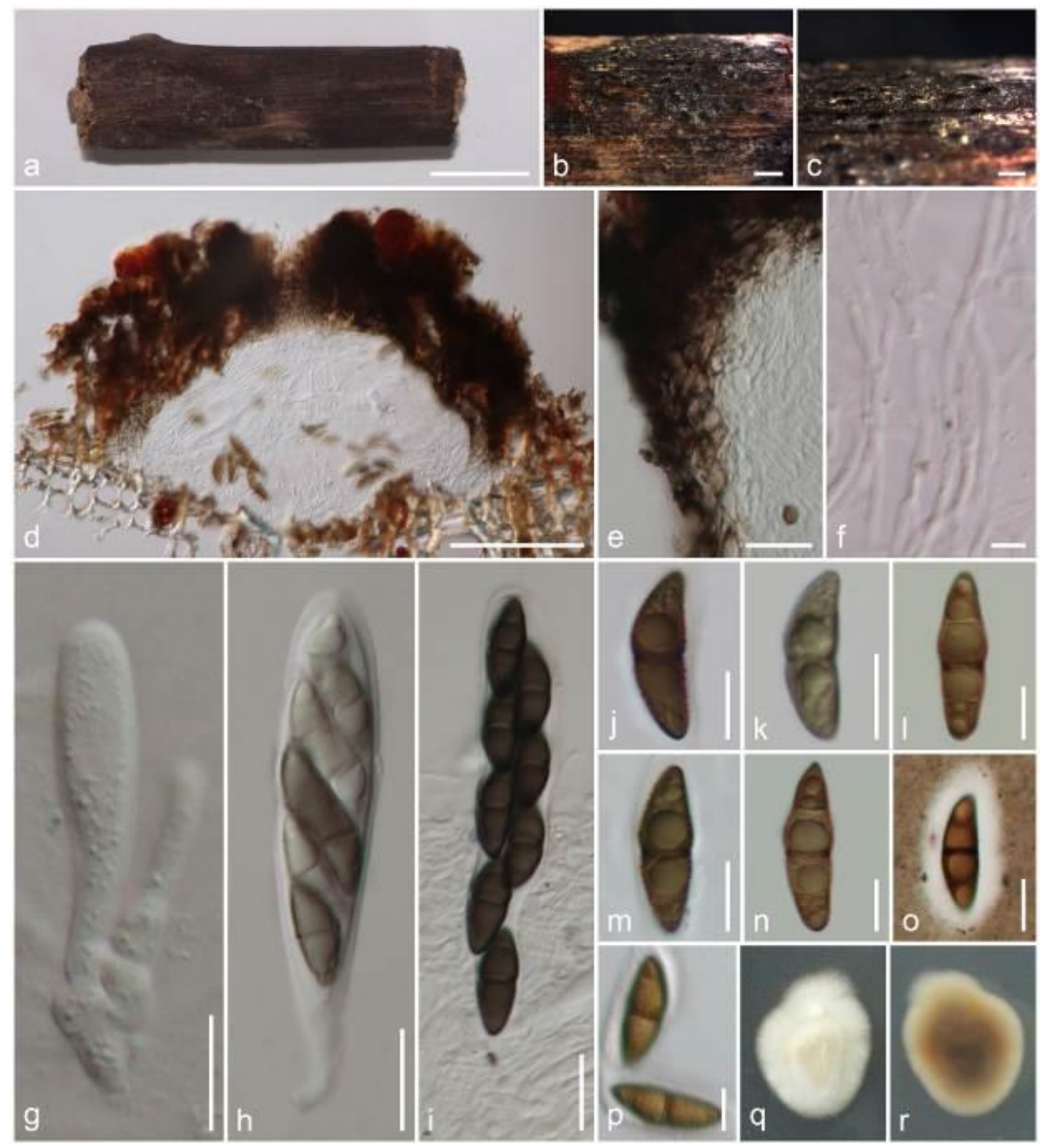

Figure 15 - Helicascus chiangraiensis (MFLU 19-2103). a-c Ascomata on the substrate. d Cross section of ascoma. e Section of the peridium. f Pseudoparaphyses. g-i Asci. j-o Ascospores (o in Indian ink). $p$ Verruculose ascospores. Culture grow on PDA q. upper side, r. reverse side. Scale bars: $\mathrm{a}=1 \mathrm{~cm}, \mathrm{~b}=1000 \mu \mathrm{m}, \mathrm{c}=500 \mu \mathrm{m}, \mathrm{d}=100 \mu \mathrm{m}, \mathrm{e}, \mathrm{h}, \mathrm{i}=20 \mu \mathrm{m}, \mathrm{g}, \mathrm{j}-\mathrm{p}=10 \mu \mathrm{m}, \mathrm{f}=5 \mu \mathrm{m}$.

\section{Phaeosphaeriaceae M.E. Barr}

Barr (1979) introduced Phaeosphaeriaceae which comprises 83 genera (Phookamsak et al. 2014, 2017, 2019, Wijayawardene et al. 2014, 2017a, 2018a, b, Hyde et al. 2016, Yang et al. 2019, 
Bakhshi et al. 2019, Maharachchikumbura et al. 2019, Marin-Felix et al. 2019, Hongsanan et al. 2020). Species in this family are often necrotrophic pathogens or saprobes on plants (Shoemaker \& Babcock 1992, Carson 2005, Stukenbrock et al. 2006, Cannon \& Kirk 2007, Tibpromma et al. 2017).

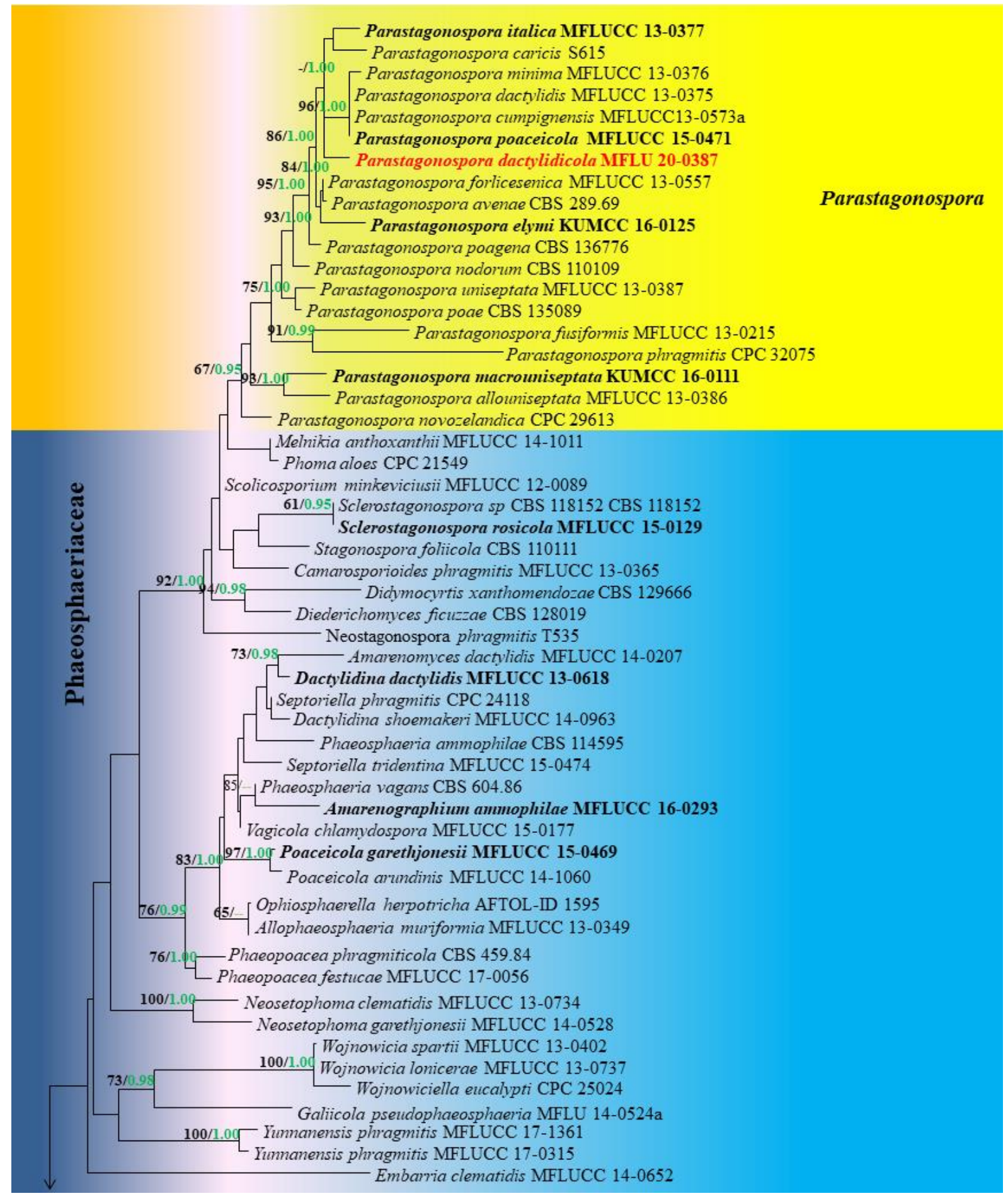

Figure 16 - Maximum likelihood analysis with 1000 bootstrap replicates yielded a best tree with the likelihood value of -25654.433343. The combined LSU, SSU and ITS sequence dataset comprised 117 strains of Phaeosphaeriaceae with Staurosphaeria rhamnicola (MFLUCC 17-0813) and (MFLUCC 17-0814) as the outgroup taxa. Tree topology of the ML analysis was similar to the BI analysis. The matrix had 1059 distinct alignment patterns, with $29.42 \%$ of undetermined characters or gaps. Estimated base frequencies were as follows; $\mathrm{A}=0.244002, \mathrm{C}=0.232592, \mathrm{G}=$ $0.265733, \mathrm{~T}=0.257673$; substitution rates $\mathrm{AC}=1.239463, \mathrm{AG}=3.249856, \mathrm{AT}=2.647426, \mathrm{CG}=$ 
$0.669460, \mathrm{CT}=7.008165, \mathrm{GT}=1.000000$; gamma distribution shape parameter $\alpha=0.610808$. Maximum likelihood bootstrap (ML, black) values equal to or greater than $65 \%$ and Bayesian posterior probabilities (PP, green) equal to or greater than $0.95 \mathrm{PP}$ are given above the nodes. The scale bar indicates 0.02 changes. The ex-type strains are in black bold and new isolates are in red bold.

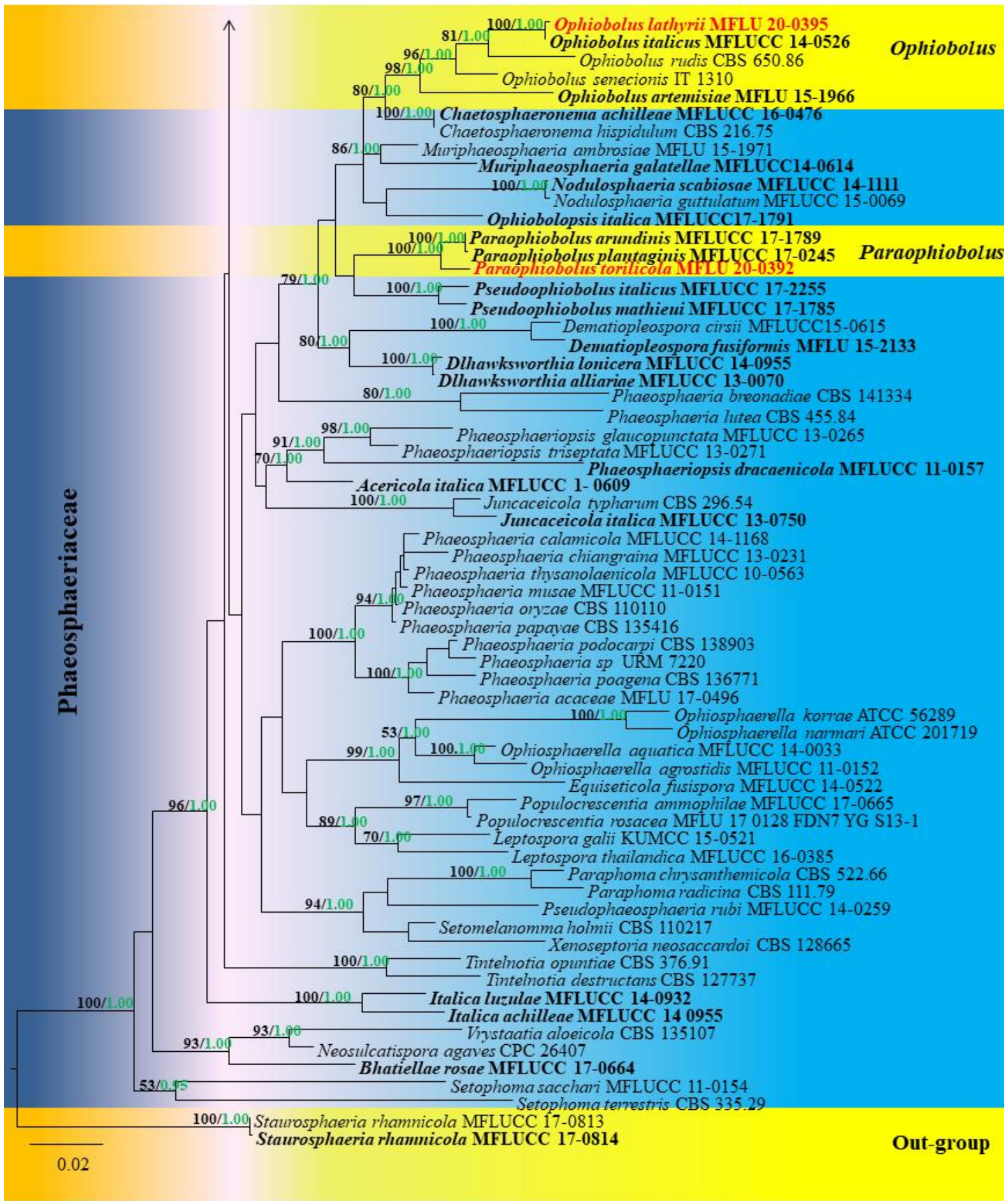

Figure 16 - Continued.

Parastagonospora Quaedvl., Verkley \& Crous, Stud. Mycol. 75: 362 (2013)

Parastagonospora is characterized by immersed ascomata with slightly papillate ostioles, bitunicate, short pedicellate asci, fusoid, subhyaline to pale brown, septate ascospores and coelomycetous asexual morphs with hyaline, cylindrical, granular to multi-guttulate, transversely 
euseptate conidia (Quaedvlieg et al. 2013, Li et al. 2015). Quaedvlieg et al. (2013) introduced this genus to accommodate several serious cereal-pathogens that were previously placed in either Septoria/Stagonospora or Leptosphaeria/Phaeosphaeria.

Parastagonospora dactylidicola Brahmanage, Camporesi \& K.D. Hyde, sp. nov.

Fig. 17

Index Fungorum number: IF557589; Facesoffungi number: FoF 08011

Entomology: Epithet refers to the host genus Dactylis of the new species.

Holotype - MFLU 20-0387

Saprobic on dead aerial stems of Dactylis glomerata. Sexual morph: Undetermined. Asexual morph: Conidiomata $100-110 \times 85-115 \mu \mathrm{m}(\overline{\mathrm{x}}=105 \times 100 \mu \mathrm{m}, \mathrm{n}=5)$, pycnidial, brown to black, erumpent or immersed to semi-immersed, globose to subglobose, ampulliform, or obpyriform, with central papillate ostiole. Pycnidial wall 35-10 $\mu \mathrm{m}$ wide, composed of outer layers of brown to dark brown cells and inner layers of hyaline cells of textura angularis. Conidiophores reduced to conidiogenous cells. Conidiogenous cells phialidic, hyaline, smooth-walled, aggregated, lining the inner cavity, ampulliform to subcylindrical, broadly cylindrical or broadly conical, with percurrent proliferation near apex. Conidia 7.5-10 $\times 2.5-3.5 \mu \mathrm{m}(\overline{\mathrm{x}}=8 \times 3 \mu \mathrm{m}, \mathrm{n}=30)$, hyaline or subhyaline, smooth-walled, thin- or thick-walled, ellipsoid to oblong, or subcylindrical, multiguttulate, with obtuse or subobtuse apex, straight to gently curved, transversely 1-septate, sometimes constricted at the septa.

Material examined - ITALY, Province of Forlì-Cesena [FC], San Lorenzo in Noceto, on dead aerial stems of Dactylis glomerata (Poaceae), 6 April 2015, E. Camporesi, IT 2433 (MFLU 200387, holotype; JZBH3460001, isotype).

GenBank Accessions - LSU: MT370430, ITS: MT370412

Notes - Parastagonospora dactylidicola is similar to stagonospora-like asexual morph. Phylogeny based on LSU and ITS sequence analyses shows that $P$. dactylidicola forms a separate lineage basal to a clade comprising Parastagonospora campignensis, P. dactylidis, $P$. minima, $P$. poaceicola (MFLUCC 15-0471) (Fig. 16). However, $P$. dactylidicola can be distinguished from $P$. dactylidis and $P$. minima based on conidial morphology. Parastagonospora dactylidicola has cylindrical to subcylindrical or fusiform conidia with narrow ends, while $P$. dactylidis has fusiform conidia with a slightly narrower base, and distinctly granular cytoplasm, whereas $P$. minima has subcylindrical conidia which are wider in the basal half, and narrow at the apex (Ghaderi \& Razavi 2018). In addition, the conidia of $P$. dactylidicola are smaller $(7.5-10 \times 2.5-3.5 \mu \mathrm{m})$ than that of $P$. dactylidis and $P$. minima. However, $P$. campignensis is known only from its asexual morph. Base pair differences of ITS gene region of the novel species to $P$. campignensis, $P$. dactylidis and $P$. minima are $4.7 \%$ (24 bp out of $506 \mathrm{bp}$, without gaps), 4.5\% (23 bp out of $505 \mathrm{bp}$, without gaps) and $4.4 \%$ (22 bp out of $492 \mathrm{bp}$, without gaps) respectively.

\section{Ophiobolus Riess}

Ophiobolus was established based on the type species $O$. phiobolus disseminans by Reiss (1854). Species in Ophiobolus are characterized by ascomata with a long cylindrical erumpent beak lined with hyaline periphyses, cylindrical to cylindric-clavate asci usually in linear fascicles, and tetraseriate, multiseptate, phragmosporous to scolecosporous, elliptical to fusiform ascospores, sometimes bearing globose appendages at each end, sometimes with band-like or cushion-shaped appendages near the first-formed septum (Shoemaker \& Babcock 1989, Phookamsak et al. 2014, 2017). Phookamsak et al. (2017) reported a polyphyletic nature of Ophiobolus-like fungi in Phaeosphaeriaceae. The type, Ophiobolus disseminans, showed close phylogenetic affinities with species of Entodesmium and Premilcurensis species. Those species were synonymized under Ophiobolus (Phookamsak et al. 2017). 

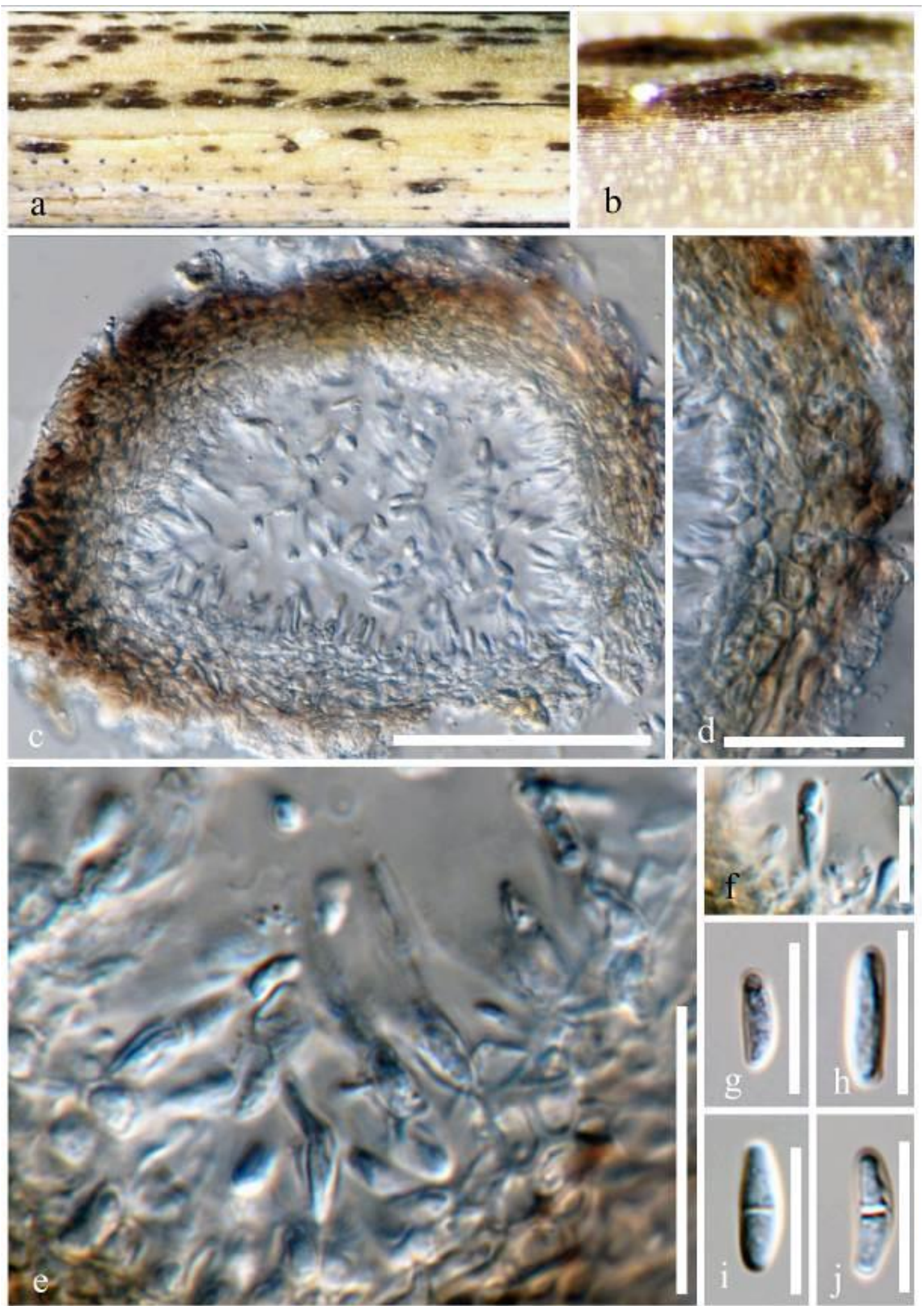

Figure 17 - Parastagonospora dactylidicola (MFLU 20-0387, holotype). a, b Conidiomata on host surface. c Vertical section through a conidioma. d Pycnidial wall. e, f Developing conidia. $\mathrm{g}-\mathrm{j}$ Conidia. Scale bars: $\mathrm{c}=50 \mu \mathrm{m}, \mathrm{d}, \mathrm{e}=20 \mu \mathrm{m}, \mathrm{f}-\mathrm{j}=10 \mu \mathrm{m}$. 
Ophiobolus lathyri Brahmanage, Camporesi \& K.D. Hyde, sp. nov.

Index Fungorum number: IF557591; Facesoffungi number: FoF 08012

Etymology - Epithet refers to the host genus Lathyrus of the new species.

Holotype - MFLU 20-0395

Saprobic on dead aerial stem of Lathyrus sp. Sexual morph: Ascomata 730-990 $\mu \mathrm{m}$ high, 430-560 $\mu \mathrm{m}$ diam. $(\overline{\mathrm{x}}=465 \times 500 \mu \mathrm{m}, \mathrm{n}=5)$, immersed to slightly erumpent, scattered beneath the host periderm or on decorticated wood, visible as small black dots on the host surface, ampulliform, solitary, ostiolate. Ostiole central, inconspicuous at the surface. Peridium 120-132 $\mu \mathrm{m}$ wide, comprising an inner layer of hyaline 2-3 elongated cell layers and an outer layer of 3-4 layers, of dark brown, thick-walled cells of textura angularis. Hamathecium comprising numerous, 2-3.5 $\mu \mathrm{m}$ wide, filamentous, unbranched, cellular, guttulate pseudoparaphyses. Asci 180-325 × 14-18 $\mu \mathrm{m}(\overline{\mathrm{x}}$ $=260 \times 16.2 \mu \mathrm{m}, \mathrm{n}=20), 8$-spored, bitunicate, fissitunicate, cylindric-clavate, with a pedicel. Ascospores $150-175 \times 4-6 \mu \mathrm{m}(\overline{\mathrm{x}}=168 \times 5.2 \mu \mathrm{m}, \mathrm{n}=30)$, overlapping triseriate, hyaline, usually 12-euseptate, not constricted at septa, rounded at the ends, guttulate, smooth-walled, lacking a mucilaginous sheath. Asexual morph: Undetermined.

Material examined - ITALY, Province of Ravenna [RA], Fognano di Brisighella, on a dead aerial stem of Lathyrus sp. (Fabaceae), 16 March 2018, E. Camporesi, IT 3782b (MFLU 20-0395, holotype).

GenBank Accessions - LSU: MT370429; SSU: MT370372, ITS: MT893362

Notes - The present molecular analyses indicate that the new strain MFLU 20-0395 clusters in Ophiobolus (Fig. 16) and we recognized it as a new species, Ophiobolus lathyri. Ophiobolus lathyri showed a close phylogenetic affinity to O. italicus (Fig. 18). Ophiobolus lathyri can be distinguished from $O$. italicus by the ascospore shape and septation. Ophiobolus lathyri has filiform, 12-euseptate ascospores, while $O$. italicus has fusiform, 4-septate ascospores (Tibpromma et al. 2017). Ophiobolus lathyri can be easily distinguished from $O$. rudis in having relatively longer ascospores $(150-175 \times 4-6 \mu \mathrm{m} v s 110-120 \times 3-4 \mu \mathrm{m})$ and 18-20 septate ascospores. Base pair differences of the LSU region of $O$. lathyri to $O$. italicus and $O$. rudis are $0.24 \%$ ( 2 bp out of $818 \mathrm{bp}$, without gaps) and $0.9 \%$ (7 bp out of $796 \mathrm{bp}$ ) respectively. ITS base pair differences of $O$. lathyri to $O$. italicus and $O$. rudis are $2.3 \%$ (12 bp out of $512 \mathrm{bp}$, without gaps) and $4.3 \%$ (22 bp out of $314 \mathrm{bp}$, without gaps) which are in recommended range to consider them as different species according to Jeewon \& Hyde (2016).

Paraophiobolus Phookamsak, Wanas. \& K.D. Hyde

Paraophiobolus was introduced by Phookamsak et al. (2017) to accommodate $P$. arundinis Phukhams., Phookamsak, Wanas., Camporesi \& K.D. Hyde and P. plantaginis (Qing Tian, Camporesi \& K.D. Hyde) Phookamsak Wanas. \& K.D. Hyde. We follow the latest treatment and updated account of Paraophiobolus in Phookamsak et al. (2017). Here, a novel species P. torilicola is introduced based on both morphology and phylogeny data.

Paraophiobolus torilicola Brahmanage, Camporesi \& K.D. Hyde, sp. nov.

Fig. 19

Index Fungorum number: IF557590; Facesoffungi number: FoF 08013

Etymology - Epithet refers to the host genus Torilis of the new species.

Holotype - MFLU 20-0392

Saprobic on dead aerial stems of Torilis arvensis. Sexual morph: Ascomata 180-310 $\times 150$ $200 \mu \mathrm{m}(\overline{\mathrm{x}}=220 \times 180 \mu \mathrm{m}, \mathrm{n}=5)$, immersed to slightly erumpent through epidermis of host, light brown at base, brown to dark brown towards the apex, scattered, solitary to gregarious, globose to subglobose, uniloculate, glabrous, ostiolate, papillate. Papilla 60-75 $\times 50-70 \mu \mathrm{m}$, mammiform to oblong, with rounded to truncate apex, composed of several layers of dark brown to black cells, arranged in a textura angularis to textura prismatica, glabrous, ostiole central, without periphyses. Peridium 16-18 $\mu \mathrm{m}$ wide, thick-walled, outer layer composed of 5-7 layers of brown to dark brown, thick-walled cells, arranged in a textura angularis, inner layer composed of 3-4 layers of hyaline, thin-walled cells of textura angularis, thicker towards the apex. Hamathecium comprising 
numerous, 1-2.5 $\mu \mathrm{m}$ wide, broad, branched, septate, cellular pseudoparaphyses, embedded in a gelatinous matrix. Asci $45-100 \times 4.5-5 \mu \mathrm{m}(\overline{\mathrm{x}}=65 \times 4.8 \mu \mathrm{m}, \mathrm{n}=40), 8$-spored, bitunicate, cylindrical to cylindrical-clavate, with short furcate pedicel, apically rounded, ocular chamber clearly visible when immature. Ascospores $40-60 \times 1-2 \mu \mathrm{m}(\overline{\mathrm{x}}=78 \times 3 \mu \mathrm{m}, \mathrm{n}=30)$, fasciculate, scolecosporous, filiform, with rounded ends, tapered towards the lower cells, hyaline to pale yellowish when young, becoming yellowish green at maturity, slightly curved near the apex, with around 11-13 eu-septa, swollen near the base of the $4^{\text {th }}$ cell, slightly constricted at the $4^{\text {th }}$ septum, not constricted at the other septa, not separating into part spores, smooth-walled, with terminal appendages at the ends. Asexual morph: Undetermined.

Material examined - ITALY, Province of Forlì-Cesena [FC], Voltre - Civitella di Romagna, dead aerial stem of Torilis arvensis (Huds.) Link (Apiaceae), 22 January 2018, E. Camporesi, IT 3689 (MFLU 20-0392, holotype; JZBH3460002, isotype).

GenBank Accessions - LSU MT370428, ITS: MT370411

Notes - Multi-gene phylogenetic analyses of combined LSU, SSU and ITS sequence dataset indicate that Paraophiobolus torilicola groups with the members of Paraophiobolus with high statistical support (100\% ML, 1.00 PP) (Fig. 16). Paraophiobolus torilicola is phylogenetically closely related to $P$. arundinis and $P$. plantaginis. However, $P$. arundinis is different from $P$. torilicola in having relatively larger ascospores $(70-85 \times 2.5-3 \mu \mathrm{m} v \mathrm{~s} 40-60 \times 1-2 \mu \mathrm{m})$. Paraophiobolus plantaginis is easily distinguished from $P$. torilicola by the number of ascospore septa (5-8 vs 11-13). A synopsis of the host and the morphological characteristics of Paraophiobolus species is given in Table 2. Base pair differences of the ITS region of $P$. torilicola with $P$. arundinis and $P$. plantaginis are 1.8\% (16 bp out of $899 \mathrm{bp}$ ) and 1.7\% (15 bp out of 899 bp), respectively.

Table 2 Synopsis of Paraophiobolus species discuss in this study

\begin{tabular}{|c|c|c|c|c|}
\hline Species & Hosts & Ascomata $(\mu \mathrm{m})$ & Asci $(\mu \mathrm{m})$ & Ascospores $(\mu \mathrm{m})$ \\
\hline P. arundinis & Arundo pliniana & $170-410 \times 110-400$ & $75-110 \times 7-12$ & $\begin{array}{l}70-8592.5-3,12(-16)- \\
\text { septate }\end{array}$ \\
\hline P. plantaginis & Plant & $145-2$ & $69-124 \times 7.4-9.5$ & $50-72 \times 4-6,5-8$-septate \\
\hline P. torilicola & Torilis arvensis & $100-110 \times 102-106$ & $45-100 \times 4.5-5$ & $\begin{array}{l}40-60 \times 1-2,11-13- \\
\text { septate }\end{array}$ \\
\hline
\end{tabular}

\section{Pleosporaceae}

Pleosporaceae was introduced by Nitschke (1869) based on the immersed ascomata and presence of pseudoparaphyses, which was assigned to Sphaeriales. Pleosporaceae species are pathogens or saprobes on wood and dead herbaceous stems or leaves (Sivanesan 1984). The asexual morphs of Pleosporaceae can be hyphomycetes (Hyde et al. 2013, Ariyawansa et al. 2015c). Pleosporaceae comprises 24 genera (Wijayawardene et al. 2020).

\section{Alternaria Nees}

Nees (1816) introduced Alternaria based on A. tenuis as the only species. Later the type specimen of Torula alternata Fr. 1832 was identified by Simmons as synonymous with Nees (1816) description of A. tenuis; therefore, he declared A. alternata as the type for the genus (Simmons 1967). Alternaria species can be saprobes or pathogens on vegetation and often found on soil, air, dust and water-damaged buildings (Ellis 1971, Ellis \& Sinclair 1976, Runa et al. 2009, Woudenberg et al. 2013, Lawrence et al. 2016). Some species have been described from polypropylene, rubber, fluorine plastics and jet fuel (Sheridan \& Soteros 1974, Lugauskas et al. 2003, Al Ghafri et al. 2019). However, the majority of species are pathogens, infecting number of host species, including major greenhouse and field crops such as carrot, cucurbits, date, palm, tomato, tobacco and wheat (Al-Nadabi et al. 2018, Jayawardena et al. 2019a). Other species of Alternaria have been reported as food spoilers and postharvest pathogens that contaminate cereals, fruit and nuts (Pitt \& Hocking 1997, Andersen \& Hollensted 2008, Lawrence et al. 2016, Al Ghafri 
et al. 2019).
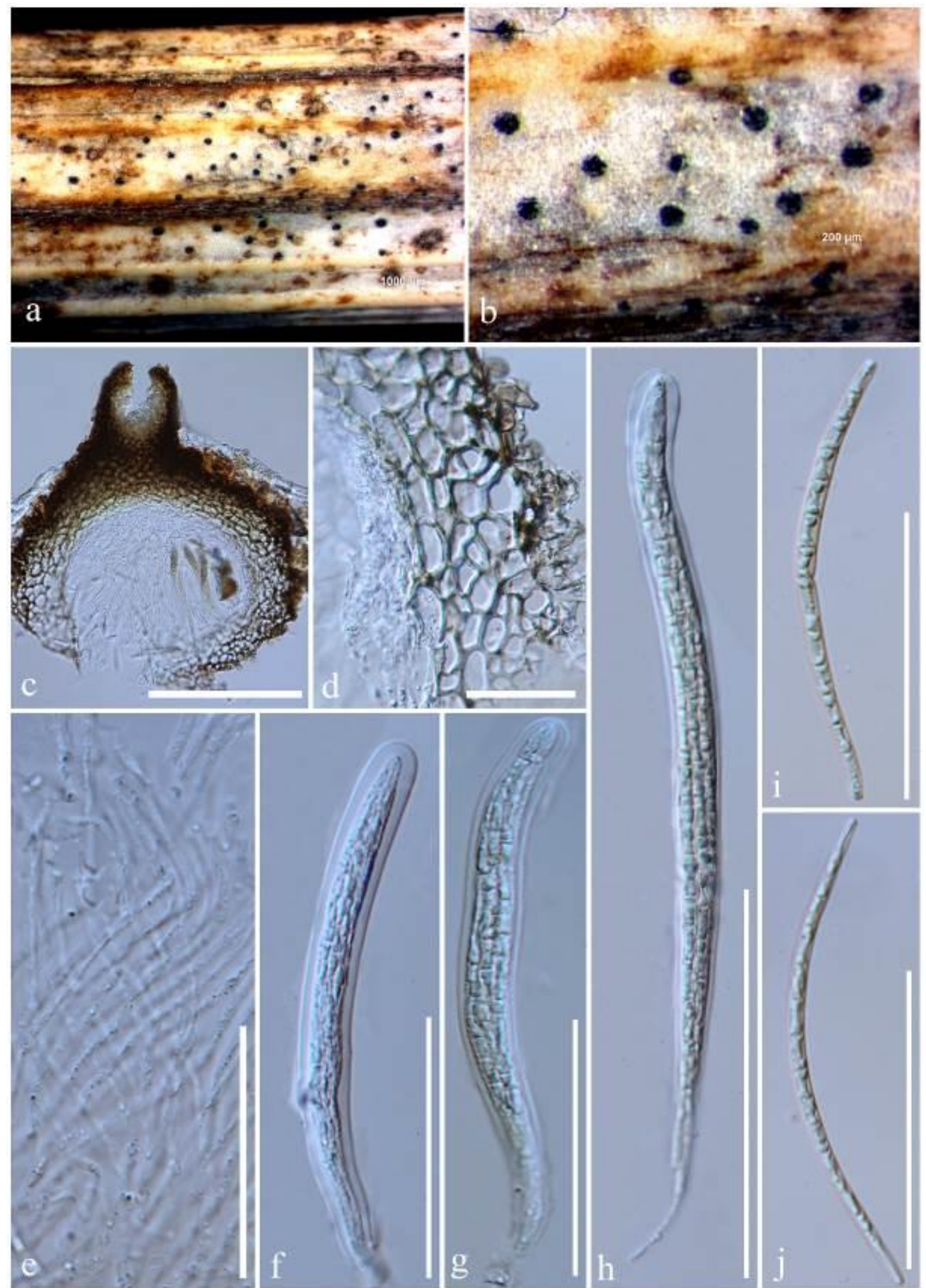

Figure 18 - Ophiobolus lathyri (MFLU 20-0395, holotype). a Appearance of ascomata on host. b Close-up of ascomata. c Section of an ascoma. d Section of peridium. e Pseudoparaphyses. $\mathrm{f}-\mathrm{h}$ Asci. i, j Ascospores. Scale bars: $\mathrm{c}=500 \mu \mathrm{m}, \mathrm{d}=100 \mu \mathrm{m}, \mathrm{f}-\mathrm{h}=200 \mu \mathrm{m}, \mathrm{i}-\mathrm{j}=100 \mu \mathrm{m}$. 


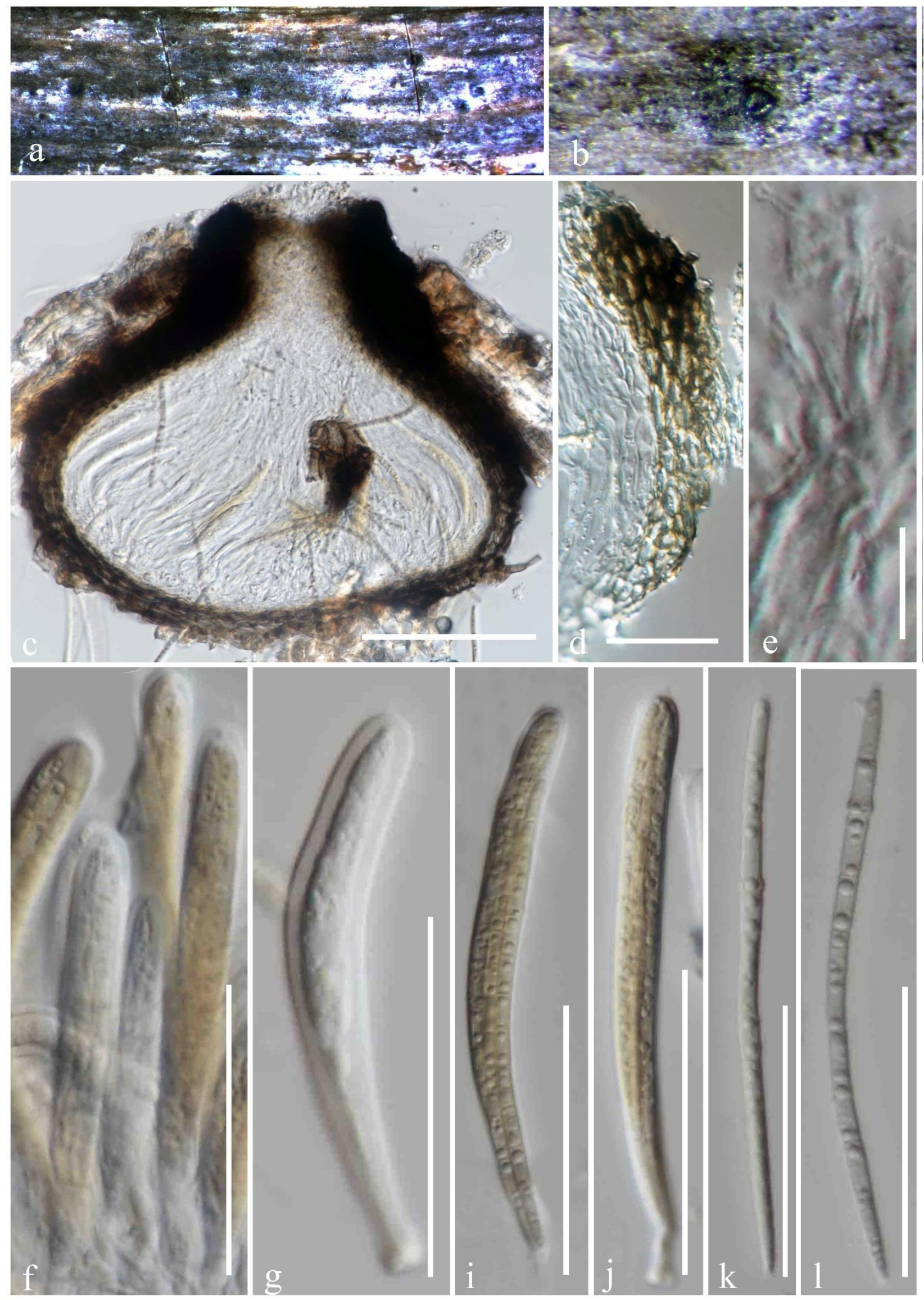

Figure 19 - Paraophiobolus torilicola (MFLU 20-0392, holotype). a Appearance of ascomata on host. b Close-up of ascomata c Section of an ascoma. d Section of peridium. e Pseudoparaphyses. $\mathrm{f}-\mathrm{j}$ Asci. $\mathrm{k}, 1$ Ascospores. Scale bars: $\mathrm{c}=100 \mu \mathrm{m}, \mathrm{e}-\mathrm{j}=50 \mu \mathrm{m}, \mathrm{d}, \mathrm{k}-\mathrm{l}=20 \mu \mathrm{m}$. 
Alternaria rumicis Brahmanage, Camporesi \& K.D. Hyde, sp. nov.

Fig. 21

Index Fungorum number: IF557587; Facesoffungi number: FoF 08017

Etymology - Species epithet refers to the host genus Rumex, of the new species

Holotype - MFLU 20-0396

Saprobic on dead aerial stems. Sexual morph: Ascomata $180-250 \times 220-260 \mu \mathrm{m}(\overline{\mathrm{x}}=210 \times$ $250 \mu \mathrm{m}, \mathrm{n}=5$ ), black, solitary to gegrarious, semi-immersed to erumpent, base fused with host substrate, globose to subglobose, with broadly to narrowly, oblong and flattened papilla. Papilla smooth, ostiolar canal filled with hyaline cells. Peridium 30-42 $\mu \mathrm{m}$ wide, slightly thin, thick at the sides and thinner at the base, composed of heavily pigmented, thick-walled cells of textura angularis, coriaceous. Hamathecium of 1-2 $\mu \mathrm{m}$ wide, cellular, septate, broad, dense pseudoparaphyses. Asci $110-150 \times 25-35 \mu \mathrm{m}(\overline{\mathrm{x}}=140 \times 30 \mu \mathrm{m}, \mathrm{n}=20), 8$-spored, bitunicate, cylindrical to clavate, with short pedicel and minute ocular chamber. Ascospores 25-38 $\times 14-16$ $\mu \mathrm{m}(\overline{\mathrm{x}}=35 \times 15 \mu \mathrm{m}, \mathrm{n}=30)$, partially overlapping, uni- to bi-seriate, mostly ellipsoidal, muriform, 3-5 transverse septa with 1 longitudinal septum in the central segments, end cells without septa, brown or pale brown, with a thick sheath. Asexual morph: Undetermined.

Culture characteristics - Conidia germinating on PDA within $14 \mathrm{~h}$ and reaching $4 \mathrm{~cm}$ diam. in 15 days at $25^{\circ} \mathrm{C}$. Colonies growing on PDA, hairy or cottony, white to grey, mycelium superficial, effuse, radially striate, white to grey.

Material examined - ITALY, Province of Forlì-Cesena [FC], Magliano-Forlì, dead aerial stems of Sinapis alba (Brassicaceae), 28 April 2018, E. Camporesi, IT 3866 (MFLU 20-0396, holotype; JZBH3180036, isotype), ex-type living culture, JZB3180036; ibids., Collina-Forlì, dead aerial stem of Dactylis glomerata (Poaceae), 28 April 2018, E. Camporesi, IT 3683 (MFLU 200400; JZBH3180037); Santa Sofia, dead aerial stem of Rumex sp. (Polygonaceae), 8 March 2014, E. Camporesi, IT 1758 (MFLU 20-0401; JZBH3180038); Tontola di Predappio, dead aerial stem of Scabiosa sp. (Caprifoliaceae), 19 March 2018, E. Camporesi, IT 3803 (MFLU 20-0402; JZBH3180039); Ravenna, Fognano di Brisighella, dead aerial stem of Lathyrus sp. (Fabaceae), 16 March 2018, E. Camporesi, IT 3779 (MFLU 20-0403; JZBH3180040).

GenBank Accessions - (MFLU 20-0396) ITS: MT370417; GAPDH: MT994321 (MFLU 200400) ITS: MT370416; GAPDH: MT994318; (MFLU 20-0401) ITS: MT370413; GAPDH: MT729647; (MFLU 20-0402) ITS: MT370415; GAPDH: MT994320; (MFLU 20-0403) ITS: MT370414; GAPDH: MT994319Notes - Alternaria rumicis is phylogenetically closely related to A. ventricosa R.G. Roberts in Alternaria section infectoria (96\% ML, 1.00 PP; Fig. 20). Alternaria ventricosa is known only from the sexual morph (Roberts 2007). Base pair differences of $A$. rumicis and A. ventricosa for ITS and GAPDH regions are $0.6 \%$ (3 bp out of $531 \mathrm{bp}$ ) and $1.56 \%$ (8 bp out of 519 bp).

\section{Comoclathris Clem.}

Comoclathris typified by Comoclathris lanata Clem., is characterized by ascomata with circular lid-like openings and applanate, reddish-brown to dark reddish-brown, muriform ascospores (Zhang et al. 2012, Ariyawansa et al. 2014, 2015a). Based on phylogenetic analyses Comoclathris was accepted in Pleosporaceae (Ariyawansa et al. 2015a, b, Wijayawardene et al. 2017). There are 44 epithets listed in Index Fungorum (2020) under this genus and most of them lack DNA sequence data. In this study we updated the genus with three new species which were collected from Italy.

Comoclathris europaeae Brahmanage, Camporesi \& K.D. Hyde, sp. nov.

Fig. 23

Index Fungorum number: IF557585, Facesoffungi number: FoF08014

Etymology - Species epithet refers to the host epithet "Olea europaea".

Holotype: MFLU 20-0391

Saprobic on dead stems of dead land leaves of Olea europaea. Sexual morph: Ascomata 240 $250 \mu \mathrm{m} \times 145-165 \mu \mathrm{m}(\overline{\mathrm{x}}=245 \times 150 \mu \mathrm{m}, \mathrm{n}=5)$, solitary, scattered, semi-immersed to slightly erumpent, dark brown to black, globose to subglobose, without a distinct ostiole. 


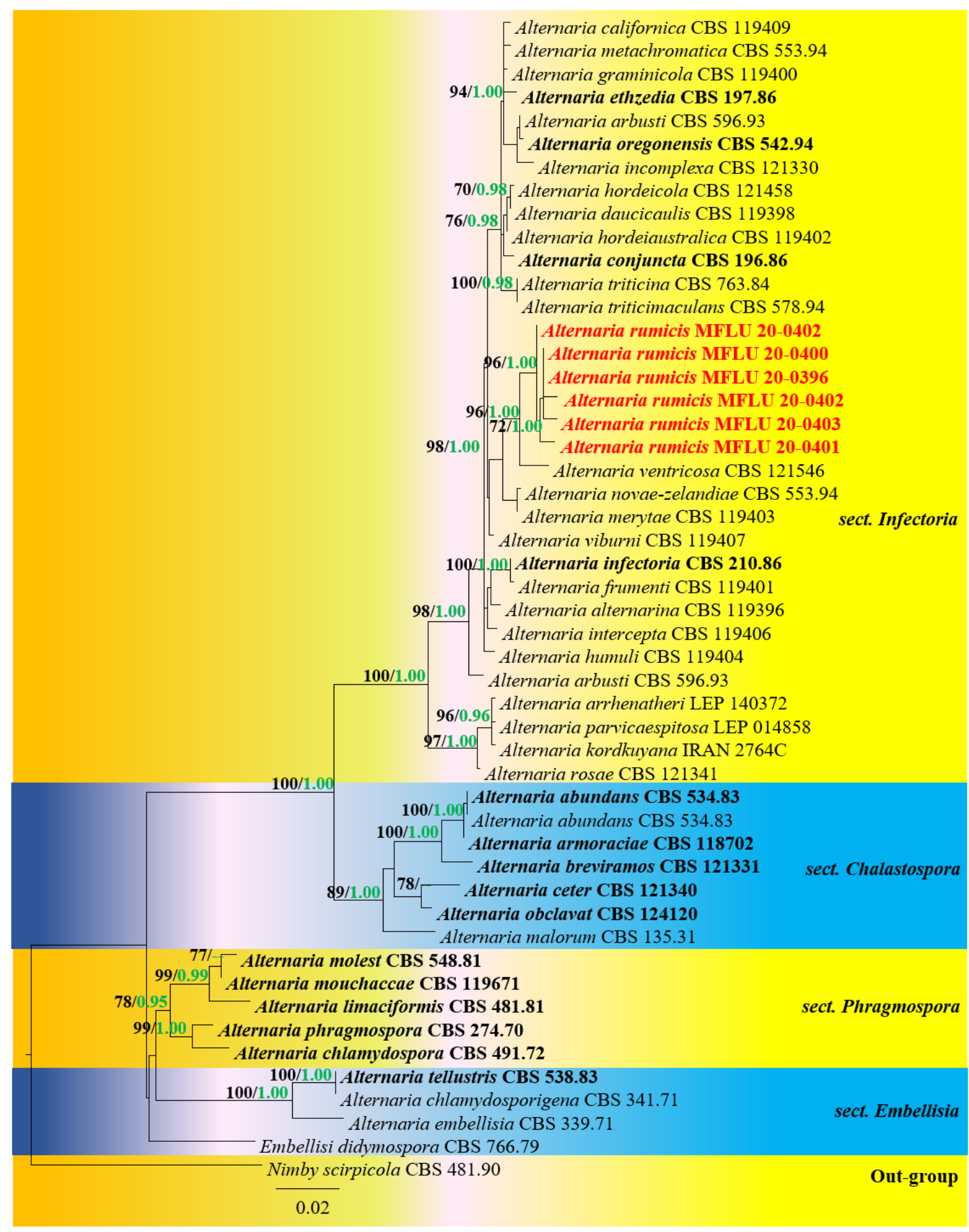

Figure 20 - Maximum likelihood analysis with 1000 bootstrap replicates yielded a best tree with the likelihood value of -18854.981529 . The combined ITS and GAPDH sequence dataset comprised 50 strains of Alternaria with Nimby scirpicola (CBS 481.90) as the outgroup taxon. Tree topology of the ML analysis was similar to the BI analysis. The matrix had 764 distinct alignment patterns, with $4.72 \%$ of undetermined characters or gaps. Estimated base frequencies were as follows; $\mathrm{A}=0.241585, \mathrm{C}=0.261062, \mathrm{G}=0.262479, \mathrm{~T}=0.234874$; substitution rates $\mathrm{AC}=$ 1.843223, $\mathrm{AG}=4.648646, \mathrm{AT}=1.463605, \mathrm{CG}=0.917951, \mathrm{CT}=7.866437, \mathrm{GT}=1.000000$; gamma distribution shape parameter $\alpha=0.182190$. Maximum likelihood bootstrap (ML, black) values equal to or greater than $65 \%$ and Bayesian posterior probabilities (PP, green) equal to or greater than $0.95 \mathrm{PP}$ are given above the nodes. The scale bar indicates 0.02 changes. The ex-type strains are in black bold and new isolates are in red bold. 

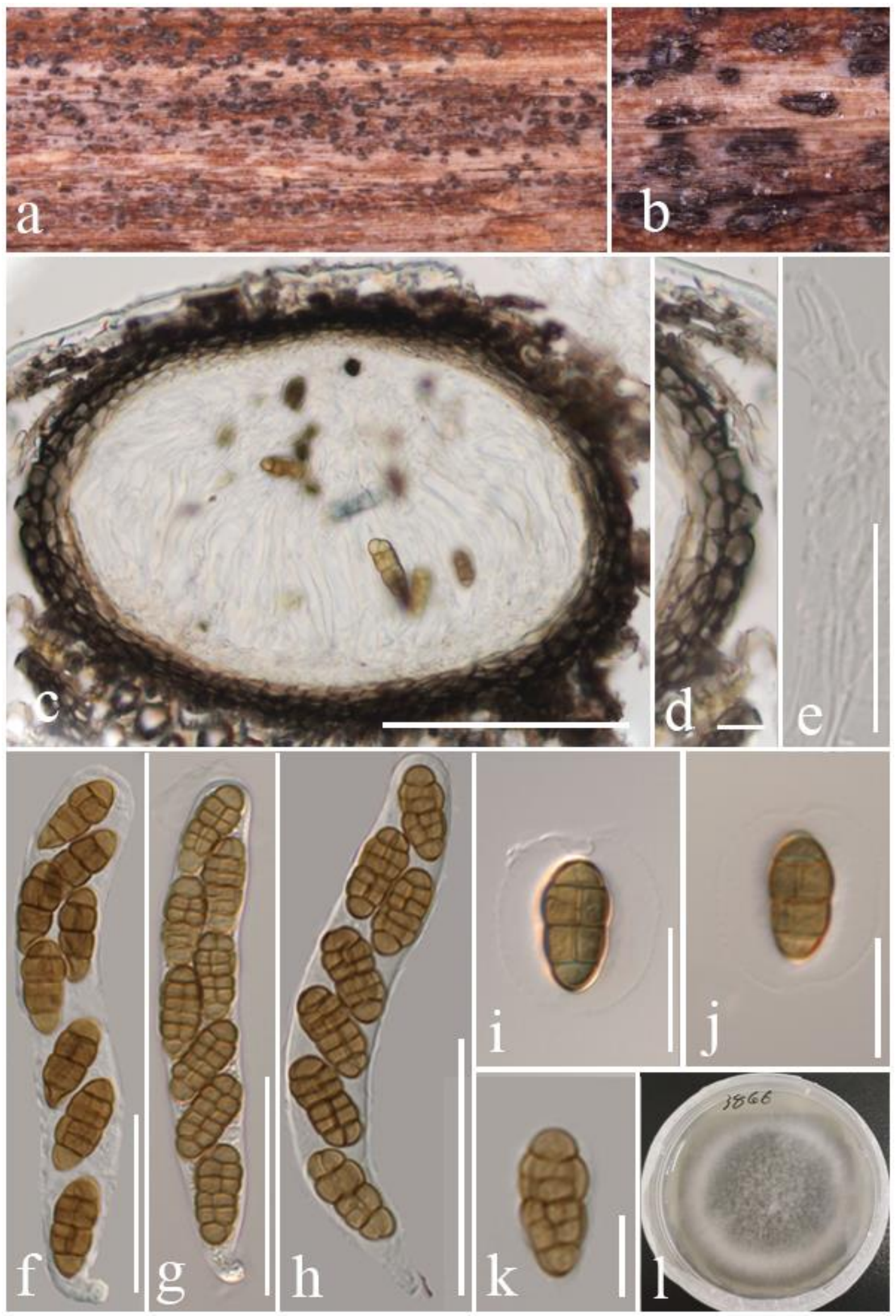

Figure 21 - Alternaria rumicis (MFLU 20-0396, holotype). a, b Ascomata on host surface. c Vertical section through an ascoma. d Peridium. f-h Asci. i-k Ascospores. 1 Culture on PDA (upper view). Scale bars: $\mathrm{c}=100 \mu \mathrm{m}, \mathrm{e}-\mathrm{i}=50 \mu \mathrm{m}, \mathrm{d}, \mathrm{j}, \mathrm{k}=20 \mu \mathrm{m}$. 


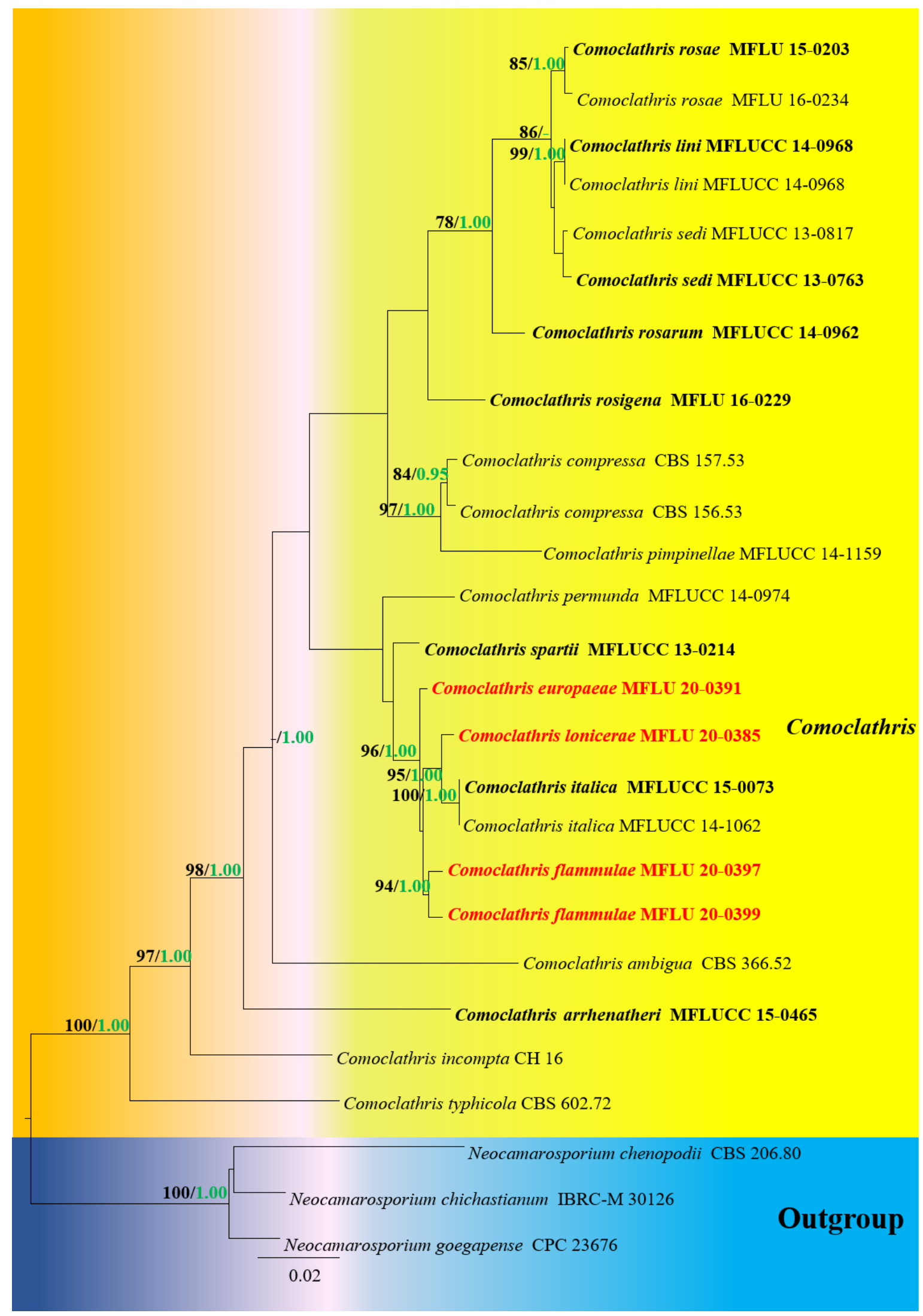

Figure 22 - Maximum likelihood analyses with 1000 bootstrap replicates yielded a best tree with the likelihood value of -10271.393559 . The combined LSU, SSU, ITS and RPB2 sequence dataset comprised 25 strains with Neocamarosporium chichastianum (IBRC M 30126), N. chenopodii (CBS206.80) and N. goegapense (CPC 23676) as the outgroup taxa. Tree topology of the ML analysis was similar to the BI analysis. The matrix had 393 distinct alignment patterns, with $26.53 \%$ of undetermined characters or gaps. Estimated base frequencies were as follows; $\mathrm{A}=$ 
$0.250308, \mathrm{C}=0.247190, \mathrm{G}=0.270102, \mathrm{~T}=0.232400 ;$ substitution rates $\mathrm{AC}=2.125141, \mathrm{AG}=$ 4.267562, $\mathrm{AT}=1.161328, \mathrm{CG}=0.955650, \mathrm{CT}=7.483498, \mathrm{GT}=1.000000 ;$ gamma distribution shape parameter $\alpha=0.162915$. Maximum likelihood bootstrap (ML, black) values equal to or greater than $65 \%$ and Bayesian posterior probabilities (PP, green) equal to or greater than $0.95 \mathrm{PP}$ are given above the nodes. The scale bar indicates 0.03 changes. The ex-type strains are in black bold and new isolates are in red bold.

Peridium 10-30 $\mu \mathrm{m}$ wide, dark brown to lightly pigmented cells of textura angularis. Hamathecium composed of 1-1.5 $\mu \mathrm{m}$ diam., hyaline, septate, anastomosed pseudoparaphyses. Asci 60-70 × 15-18 $\mu \mathrm{m}(\overline{\mathrm{x}}=65 \times 16.5 \mu \mathrm{m}, \mathrm{n}=10), 8$-spored, bitunicate, fissitunicate, cylindro-clavate, pedicellate, apex rounded, with an indistinct ocular chamber. Ascospores $20-22 \times 11-13 \mu \mathrm{m}(\overline{\mathrm{x}}=$ $21 \times 12.8 \mu \mathrm{m}, \mathrm{n}=20$ ), uni- to biseriate, partially overlapping, muriform, brown, transversely septate or muriform, with 7 transverse septa, one longitudinal septum at central segments, ellipsoidal to clavate, with acute end at the apex and rounded end at the base, upper half slightly wider and shorter than the lower half cell, constricted at the primary septum, surrounded by a mucilaginous sheath. Asexual morph: Undetermined.

Material examined - ITALY, Province of Forlì-Cesena [FC], Vitignano-Meldola, on dead land leaves of Olea europaea (Oleaceae), 20 January 2018, E. Camporesi, IT 3684 (MFLU 200391, holotype; JZBH3450002, isotype).

GenBank Accessions - LSU: MT370421; SSU: MT370367; ITS: MT370396; RPB2: MT729650

Notes - Comoclathris europaeae is similar to $C$. flammulae and it shows close phylogenetic affinities to $C$. lonicerae (MFLU 20-0385), C. flammulae (MFLU 20-0397, MFLU 20-0399) and $C$. italica (MFLUCC 15-0073, MFLUCC 14-1062) with high statistical support (96\% ML, 1.00 PP; Fig 22). Their base pair differences within the ITS regions are C. flammulae (9/562 (1.60\%), no gaps), C. italica (5/480 (1.04\%), no gaps) and C. lonicerae (5/500 (1.00\%), no gaps). Base pair differences within the RPB2 region are (7/521 (1.34 \%), no gaps), C. italica (25/847 (2.95\%) and C. lonicerae (17/869 (1.95\%), no gaps. Furthermore, C. europaeae has smaller asci $(60-70 \times 15-18$ $\mu \mathrm{m})$ than those of $C$. lonicerae $(180-192 \times 60-74 \mu \mathrm{m})$. Comoclathris europaeae has smaller asci $(60-70 \times 15-18 \mu \mathrm{m})$ and ascospores $(20-22 \times 11-13 \mu \mathrm{m})$ than those of $C$. italica (asci: 100-120 $\times$ 30-35 $\mu \mathrm{m}$ and ascospores: $30-35 \times 10-15 \mu \mathrm{m})$.

Comoclathris flammulae Brahmanage, Camporesi \& K.D. Hyde, sp. nov.

Fig. 24

Index Fungorum number: IF557584; Facesoffungi number: FoF 08015

Etymology - Species epithet refers to the host species epithet "flammula"

Holotype: MFLU 20-0397

Saprobic on dead aerial branches of Clematis flammula and Colutea arborescens. Sexual morph: Ascomata 105-130 $\mu \mathrm{m} \times 80-90 \mu \mathrm{m}(\overline{\mathrm{x}}=120 \times 86 \mu \mathrm{m}, \mathrm{n}=5)$, solitary or aggregated, immersed, globose to subglobose, dark brown to black, without a distinct ostiole. Peridium 14-30 $\mu \mathrm{m}$ wide, comprising 2-4 layers of dark brown to brown, thick-walled cells of textura angularis. Hamathecium comprising numerous, 1-1.5 $\mu \mathrm{m}$ wide, septate, pseudoparaphyses. Asci 50-55 $\times 13-$ $17 \mu \mathrm{m}(\overline{\mathrm{x}}=52 \times 15 \mu \mathrm{m}, \mathrm{n}=10), 8$-spored, bitunicate, fissitunicate, cylindric-clavate, short pedicellate, rounded at the apex, with an indistinct ocular chamber. Ascospores 16-22 $\times 10-16 \mu \mathrm{m}$ $(\overline{\mathrm{x}}=20 \times 15 \mu \mathrm{m}, \mathrm{n}=20)$, overlapping uni- to bi-seriate, yellowish brown when immature, becoming dark brown at maturity, clavate, with acute ends, muriform, with 6 transverse septa, 1-2 longitudinal septa, upper part is wider than the lower part, smooth, with a thick, hyaline, mucilaginous sheath. Asexual morph: Undetermined.

Material examined - ITALY, Province of Forlì-Cesena [FC], Bonalda-Civitella di Romagna, on dead aerial branches of Clematis flammula (Ranunculaceae), 1 June 2018, E. Camporesi, IT 3922 (MFLU 20-0397, holotype; JZBH3450003, isotype); ibid., San Martino-Predappio, dead aerial branch of Colutea arborescens (Fabaceae), 23 October 2015, E. Camporesi, 13 (MFLU 200399; JZBH3450004). 
GenBank Accessions - MFLU 20-0397) LSU: MT370397; SSU: MT370368; ITS: MT370397; RPB2: MT729651, (MFLU 20-0399) LSU: MT370420; SSU: MT370366; ITS: MT370395.
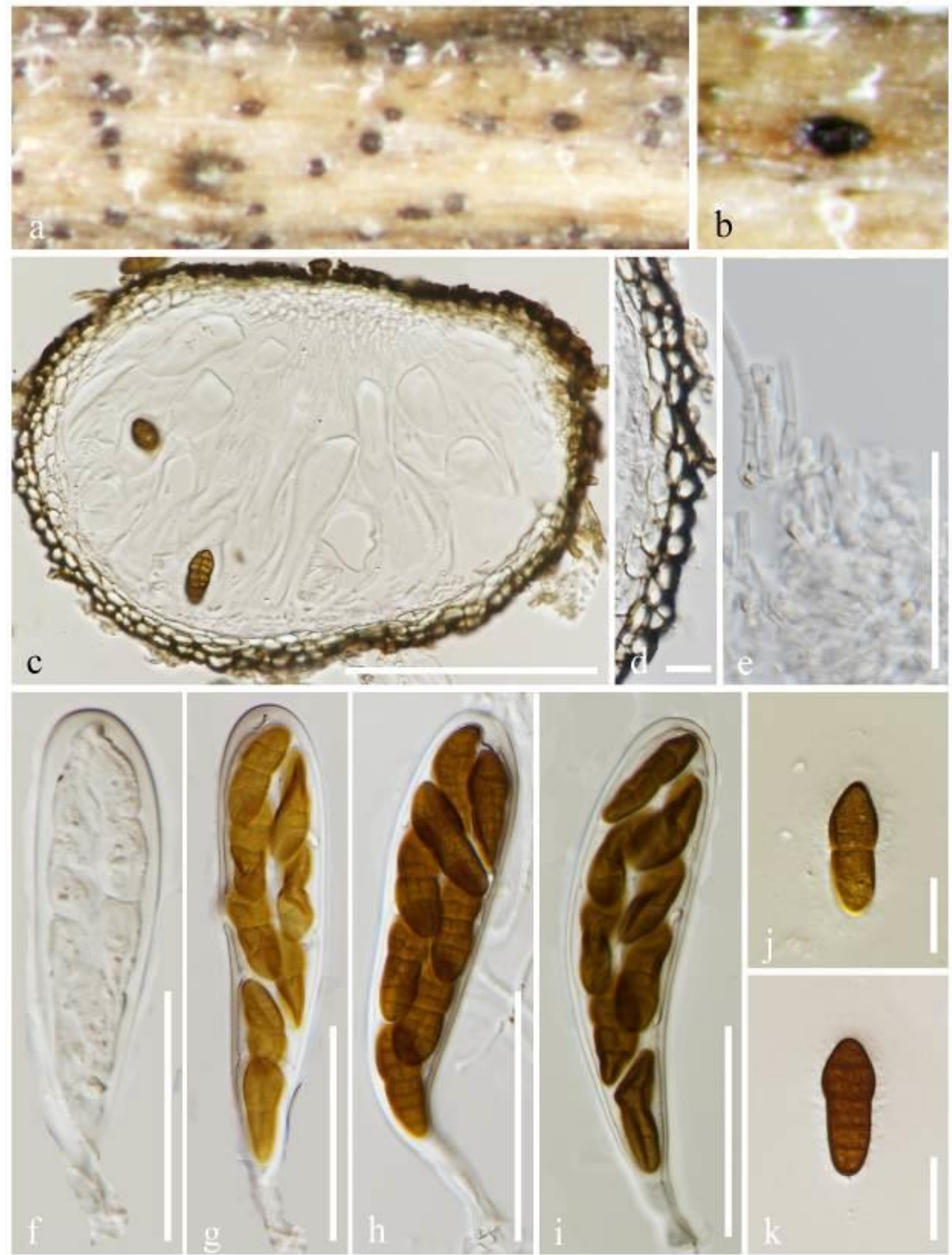

Figure 23 - Comoclathris europaeae (MFLU 20-0391, holotype). a Appearance of ascomata on host. b Close up of an ascoma. c Section through an ascoma. d Peridium. e Pseudoparaphyses. $\mathrm{f}-\mathrm{i}$ Asci. j, k Ascospores. Scale bars: $\mathrm{c}=100 \mu \mathrm{m}, \mathrm{f}-\mathrm{i}=20 \mu \mathrm{m}, \mathrm{d}, \mathrm{e}, \mathrm{j}-\mathrm{k}=10 \mu \mathrm{m}$. 


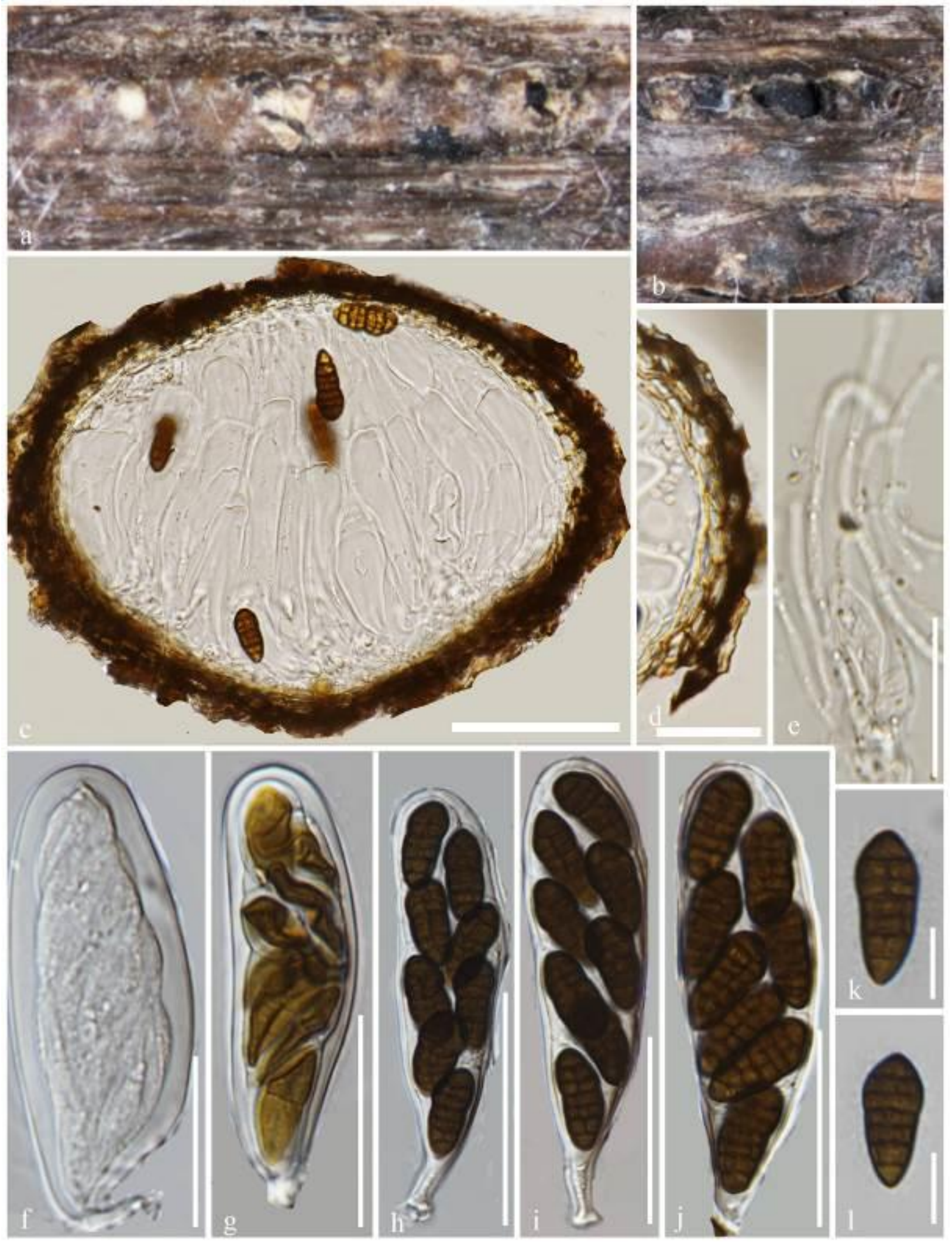

Figure 24 - Comoclathris flammulae (MFLU 20-0397, holotype). a Appearance of ascomata on host. b Close up of ascomata. c Section through an ascoma. d Peridium. e Pseudoparaphyses. $\mathrm{f}-\mathrm{j}$ Asci k, 1 Ascospores. Scale bars: $\mathrm{c}=100 \mu \mathrm{m}, \mathrm{e}-\mathrm{j}=20 \mu \mathrm{m}, \mathrm{d}, \mathrm{k}, \mathrm{l}=10 \mu \mathrm{m}$.

Notes - Isolates of Comoclathris flammulae (MFLU 20-0397 and MFLU 20-0399) grouped with statistical support (94\% ML, $1.00 \mathrm{PP}$; Fig. 22) and are closely related to C. europaeae, $C$. italica and $C$. lonicerae. Comoclathris flammulae differs from $C$. europaeae by having smaller 
ascomata $(105-130 \mu \mathrm{m} \times 80-90 \mu \mathrm{m} v s$ 240-250 $\mu \mathrm{m} \times 145-165 \mu \mathrm{m})$ and smaller asci $(48-55 \times 13-$ $17 \mu \mathrm{m} v s$ 60-70 $\times 15-18 \mu \mathrm{m})$. Comoclathris flammulae has smaller asci $(50-55 \times 13-17 \mu \mathrm{m} v \mathrm{~s}$ 100-120 × 30-35 $\mu \mathrm{m}$ ) and shorter ascospores (16-22 vs 30-35 $\mu \mathrm{m})$ than those of $C$. italica. Comoclathris flammulae can be distinguished from $C$. lonicerae mainly by their ascospore septation (6 transverse septa vs 3-5 transverse septa). Base pair differences of ITS region of Comoclathris flammulae to $C$. italica. and C. lonicerae are (7/550 (1.3\%), no gaps) and (13/564 (2.3\%), no gaps) respectively while RPB2 base pair differences are (20/861 (2.3\%), no gaps) and (12/861 (2.4\%), no gaps). Comoclathris compressa (Harkn.) Shoemaker \& C.E. Babc., C. pentamera (P. Karst.) S. Ahmad and C. sedi Wanas., Ariyaw., Camporesi \& K.D. Hyde have previously been reported from Clematis host species. This is the first report of Comoclathris species from Colutea species.

Comoclathris lonicerae Brahmanage, Camporesi \& K.D. Hyde, sp. nov.

Fig. 25

Index Fungorum number: IF557586; Facesoffungi number: FoF 08016

Etymology - Species epithet refers to the host genus Lonicera.

Holotype - MFLU 20-0385

Saprobic on dead stems of living branches of Lonicera sp., appearing as black spots on the host surface. Sexual morph: Ascomata 370-485 $\mu \mathrm{m} \times 255-360 \mu \mathrm{m}(\overline{\mathrm{x}}=460 \times 300 \mu \mathrm{m}, \mathrm{n}=10)$, solitary or aggregated, scattered, semi-immersed to erumpent, globose to subglobose, dark brown to black, without a distinct ostiole. Peridium 12-27 $\mu \mathrm{m}$ wide, comprising 2-4 layers of brown to dark brown cells of textura angularis. Hamathecium comprising numerous, 1.4-2.4 $\mu \mathrm{m}$ wide, septate, pseudoparaphyses. Asci 180-192 × 60-74 $\mu \mathrm{m}(\overline{\mathrm{x}}=185 \times 68 \mu \mathrm{m}, \mathrm{n}=20), 8$-spored, bitunicate, fissitunicate, broadly cylindrical to cylindrical-clavate, short pedicellate, rounded at the apex, with an indistinct, shallow ocular chamber. Ascospores 55-70 $\times 20-30 \mu \mathrm{m}(\overline{\mathrm{x}}=65 \times 28 \mu \mathrm{m}, \mathrm{n}=30)$, overlapping uni- or bi-seriate, yellowish brown, transversely septate or muriform, with 3-5 transverse septa, 1-2 longitudinal septa, with rounded ends, constricted at the middle septum, smooth with a thick mucilaginous sheath. Asexual morph Undetermined.

Material examined - ITALY, Province of Arezzo (AR), Montalone-Bibbiena, on living branches of Lonicera sp. (Caprifoliaceae), 5 May 2013, E. Camporesi, IT 1248 (MFLU 20-0385, holotype; JZBH3450001, isotype).

GenBank Accessions - LSU: MT370419; SSU: MT370365; ITS: MT370394; RPB2: MT729649

Notes - Comoclathris lonicerae is phylogenetically closely related to $C$. italica (MFLUCC 15-0073, MFLUCC 14-1062), but forms a well-separated lineage (95\% ML, $1.00 \mathrm{PP}$ ) in the present phylogenetic analyses (Fig. 22). Comoclathris lonicerae can easily be distinguished from $C$. italica by their larger asci $(180-192 \times 60-74 \mu \mathrm{m} v s$ 100-120 $\times 30-35 \mu \mathrm{m})$ and larger ascospores $(55-70 \times$ 20-30 $\mu \mathrm{m}$ vs 30-35 × 10-15 $\mu \mathrm{m}$ ) (Thambugala et al. 2017). The ITS and RPB2 base pair difference among these isolates are $0.58 \%$ (3 bp without gaps out of $521 \mathrm{bp}$ ) and $1.4 \%$ (12 bp without gaps out of $856 \mathrm{bp}$ ), respectively. Based on phylogenetic and morphological differences, we introduced this taxon as a new Comoclathris species. Comoclathris emodi reported from Lonicera sp. in India differs from $C$. lonicerae by having 4 transverse septa (Shoemaker \& Babcock 1992). However, there is no sequence data available to compare the phylogenetic relationship of our new species to $C$. emodi.

Stemphylium Wallr.

Stemphylium is a well-established genus typified with S. botryosum Wallr. (Woudenberg et al. 2017). It includes dematiaceous hyphomycetes and can be distinguished from other hyphomycetes in Pleosporaceae by having phaeodictyospores produced by the percurrent proliferation in its conidiophores, and apically swollen conidiogenous cells (Köhl et al. 2009). Stemphylium species are mostly pathogens on a wide range of vegetable plants, including tomato, lettuce, beans, pea and fruits (Câmara et al. 2002, Woudenberg et al. 2017, Brahmanage et al. 2018, 2019). 


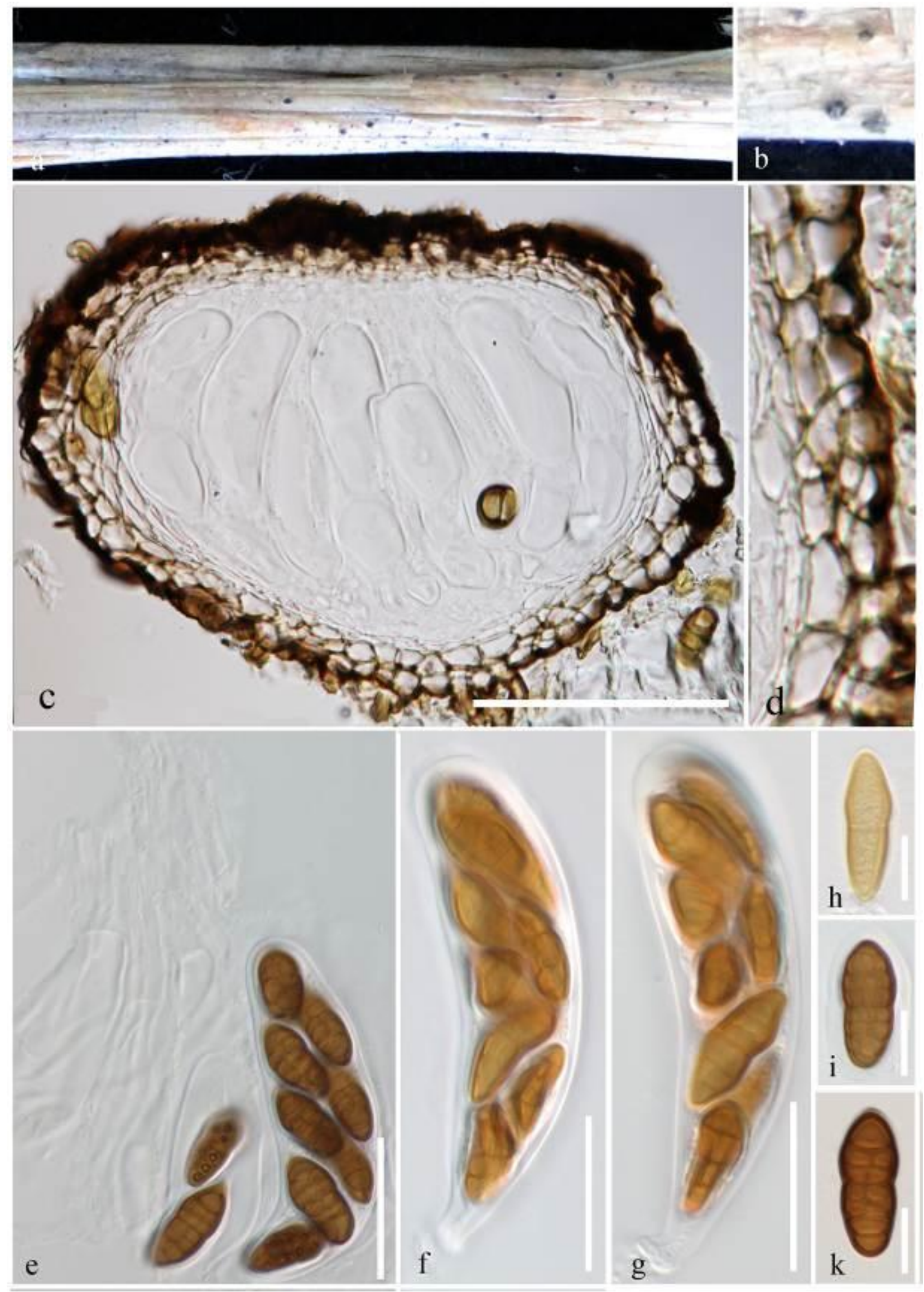

Figure 25 - Comoclathris lonicerae (MFLU 20-0385, holotype). a Appearance of ascomata on host. b Close up of ascomata. c Section through an ascoma. d Peridium. e Pseudoparaphyses and asci. f, g Asci. h-k Ascospores. Scale bars: $\mathrm{c}=100 \mu \mathrm{m}, \mathrm{e}-\mathrm{g}=50 \mu \mathrm{m}, \mathrm{h}-\mathrm{k}=20 \mu \mathrm{m}$. 
Stemphylium artemisiae Brahmanage, Camporesi \& K.D. Hyde, sp. nov.

Fig. 27

Index Fungorum number: IF557588; Facesoffungi number: FoF08018

Etymology: Name referring to the host genus Artemisia of the new species

Holotype - MFLU 20-0404

Saprobic on dead aerial stems of Artemisia sp. Sexual morph: Ascomata 80-100 $\times 130-140$ $\mu \mathrm{m}(\overline{\mathrm{x}}=90 \times 138 \mu \mathrm{m}, \mathrm{n}=5)$, black, solitary, immersed to erumpent, base not easy to remove from the substrate, subglobose to ampulliform, coriaceous, with flattened ostiolate. Ostiole minute papillate, smooth, ostiolar canal filled with hyaline cells. Peridium 10-30 $\mu \mathrm{m}$ wide, usually composed with two layers, thick at the sides and thinner at the base, outer layer of heavily pigmented thick-walled cells of textura angularis, inner layer composed of hyaline to pale barown, thin-walled cells of textura angularis. Hamathecium of 1-2 $\mu \mathrm{m}$ wide, cellular, septate, broad, dense pseudoparaphyses. Asci 40-60 × 12-16 $\mu \mathrm{m}(\overline{\mathrm{x}}=55 \times 14 \mu \mathrm{m}, \mathrm{n}=20), 8$-spored, bitunicate, fissitunicate, broadly cylindrical to cylindric-clavate, with a short pedicel and a minute ocular chamber. Ascospores 16-20 × 10-12 $\mu \mathrm{m}(\overline{\mathrm{x}}=18 \times 11.5 \mu \mathrm{m}, \mathrm{n}=30)$, uni- to bi-seriate, partially overlapping, pale brown to brown, mostly ellipsoidal, muriform with 4-7 transverse septa and 1-3 longitudinal septa, sectored, with a sheath. Asexual morph: Undetermined.

Culture characteristics - Colonies on PDA reaching $8 \mathrm{~cm}$ diam. after 2 weeks at $24^{\circ} \mathrm{C}$, later with dense mycelium, circular, smooth margin, yellowish grey, reverse brownish yellow.

Material examined - ITALY, Province of Forlì-Cesena [FC], Monte Poggiolo - Castrocaro Terme e Terra del Sole, on a dead aerial stem of Artemisia sp. (Asteraceae), 22 February 2018, E. Camporesi, IT 3742 (MFLU 20-0404, holotype; JZBH3240016, isotype), ex-type living culture ZJB3240016.

GenBank Accessions - ITS: MT370409; CAL: MT729657; GAPDH: MT729664

Notes - In our phylogenetic analysis based on combined ITS, CAL and GAPDH DNA sequences, Stemphylium artemisiae clustered with members of Stemphylium (Fig. 29). Stemphylium artemisiae shows close phylogenetic affinities with $S$. amaranthi, S. halophilum and S. lycii, but forms a distinct lineage with moderate statistical support (76\% ML, 0.91 PP) (Fig. 26). Base pair differences of $S$. artemisiae with $S$. amaranthi, S. halophilum and S. lycii are shown in Table 3. Stemphylium artemisiae differs from S. amaranthi, S. lycii and S. holophilum based on their ascospore measurements $(16-20 \times 10-12 \mu \mathrm{m} v s$ 34-41 × 14-18 $\mu \mathrm{m} v \mathrm{~s} 35-38 \times 13-15 \mu \mathrm{m})$, respectively (Woudenberg et al. 2017, Poursafar et al. 2018).

Table 3 Base pair differences of Stemphylium artemisiae to its related species

\begin{tabular}{llll}
\hline Species & ITS & GAPDH & CAL \\
\hline S. amaranthi & $0.55 \%(3 \mathrm{bp}$ out of $545 \mathrm{bp})$ & $2.8 \%(20 \mathrm{bp}$ out of $700 \mathrm{bp})$ & $1.3 \%(7 \mathrm{bp}$ out of $584 \mathrm{bp})$ \\
S. halophilum & $1.5 \%(8 \mathrm{bp}$ out of $545 \mathrm{bp})$ & $2.8 \%(20 \mathrm{bp}$ out of $700 \mathrm{bp})$ & $5.1 \%(20 \mathrm{bp}$ out of $584 \mathrm{bp})$ \\
S. lycii & $1.1 \%(6 \mathrm{bp}$ out of $545 \mathrm{bp})$ & $2.6 \%(18 \mathrm{bp}$ out of $700 \mathrm{bp})$ & $3.6 \%(21 \mathrm{bp}$ out of $584 \mathrm{bp})$ \\
\hline
\end{tabular}

Stemphylium vesicarium (Wallr.) E.G. Simmons, Mycologia 61(1): 9 (1969)

Fig. 28

Index Fungorum number: IF339660; Facesoffungi number: FoF04472

Saprobic on Dianthus pseudarmeria. Sexual morph: Ascomata 120-250 $\times 260-460 \mu \mathrm{m}(\overline{\mathrm{x}}=$ $200 \times 350 \mu \mathrm{m}, \mathrm{n}=5$ ), immersed to semi-immersed, globose to sub-globose, coriaceous, ostiolate. Ostiole papillate, ostiolar canal filled with hyaline cells. Peridium 35-55 $\mu \mathrm{m}$, composed with two layers, thick at the sides and thinner at the base, outer layer of heavily pigmented thick-walled cells of textura angularis, inner layer composed of hyaline thin-walled cells of textura angularis. Hamathecium of 2-3 $\mu \mathrm{m}$ wide, cellular, septate, broad, dense pseudoparaphyses. Asci 120-215 $\times$ 30-40 $\mu \mathrm{m}(\overline{\mathrm{x}}=142 \times 35 \mu \mathrm{m}, \mathrm{n}=20), 8$-spored, bitunicate, cylindrical to clavate, with a short pedicel and a minute ocular chamber. Ascospores $25-40 \times 12-18 \mu \mathrm{m}(\overline{\mathrm{x}}=36 \times 14 \mu \mathrm{m}, \mathrm{n}=30)$, uni- to bi-seriate or partially overlapping, mostly ellipsoidal, muriform, 6 transverse septa and 1-2 longitudinal septa, sectored, with a sheath. Asexual morph: Undetermined. 


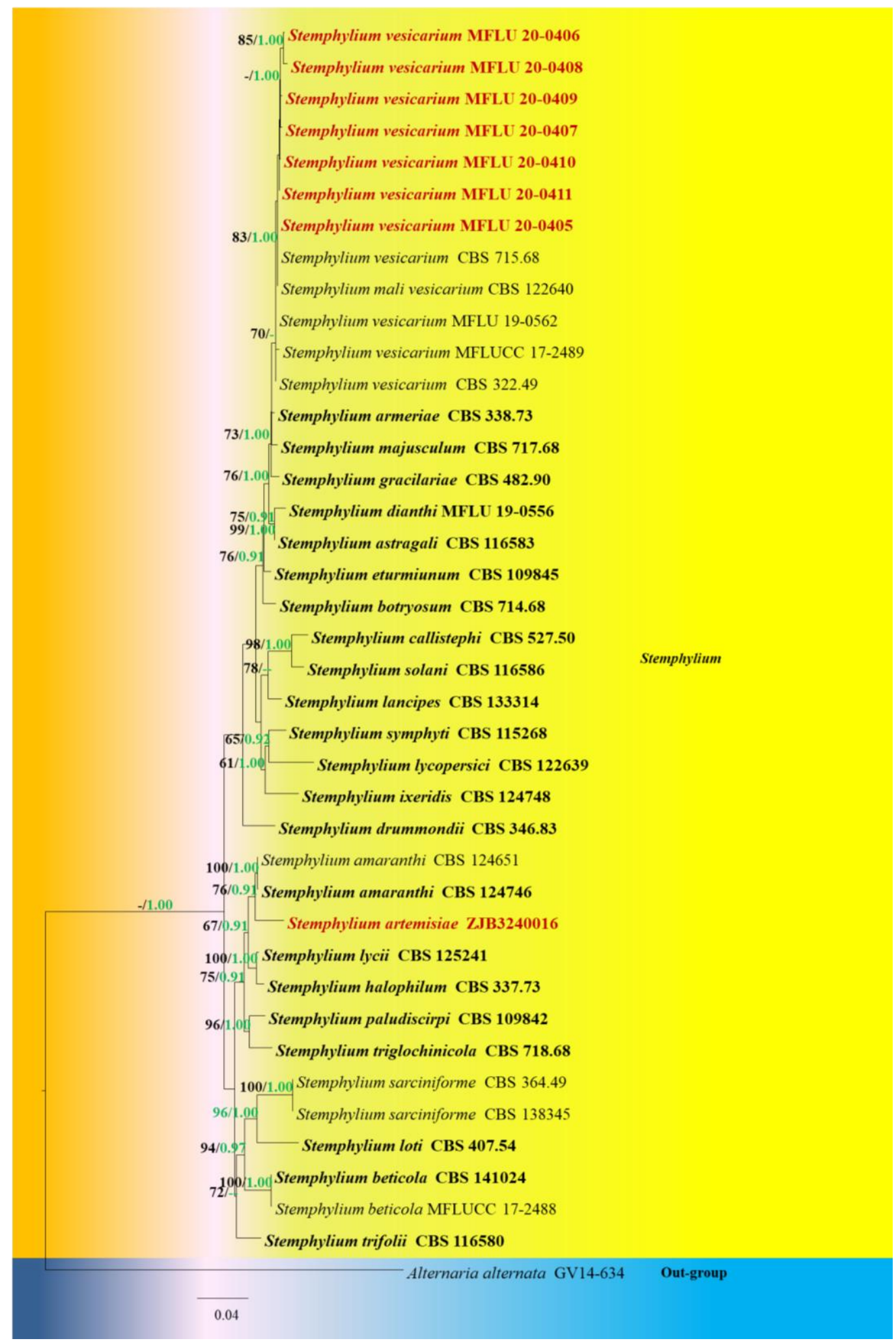

Figure 26 - Maximum likelihood analysis with 1000 bootstrap replicates yielded a best tree with the likelihood value of -7963.959646. The combined ITS, CAL and GAPDH sequence dataset comprised 40 strains of Stemphylium with Alternaria alternata (GV14634) as the outgroup taxon. Tree topology of the ML analysis was similar to the BI analysis. The matrix had 582 distinct alignment patterns, with $9.10 \%$ of undetermined characters or gaps. Estimated base frequencies were as follows; $\mathrm{A}=0.238736, \mathrm{C}=0.297155, \mathrm{G}=0.232870, \mathrm{~T}=0.231239$; substitution rates $\mathrm{AC}$ $=1.732597, \mathrm{AG}=4.848787, \mathrm{AT}=1.118155, \mathrm{CG}=1.400193, \mathrm{CT}=6.620922, \mathrm{GT}=1.000000$; gamma distribution shape parameter $\alpha=0.162791$. Maximum likelihood bootstrap (ML, black) 
values equal to or greater than $65 \%$ and Bayesian posterior probabilities (PP, green) equal to or greater than $0.95 \mathrm{PP}$ are given above the nodes. The scale bar indicates 0.04 changes. The ex-type strains are black bold and new isolates are in red bold.
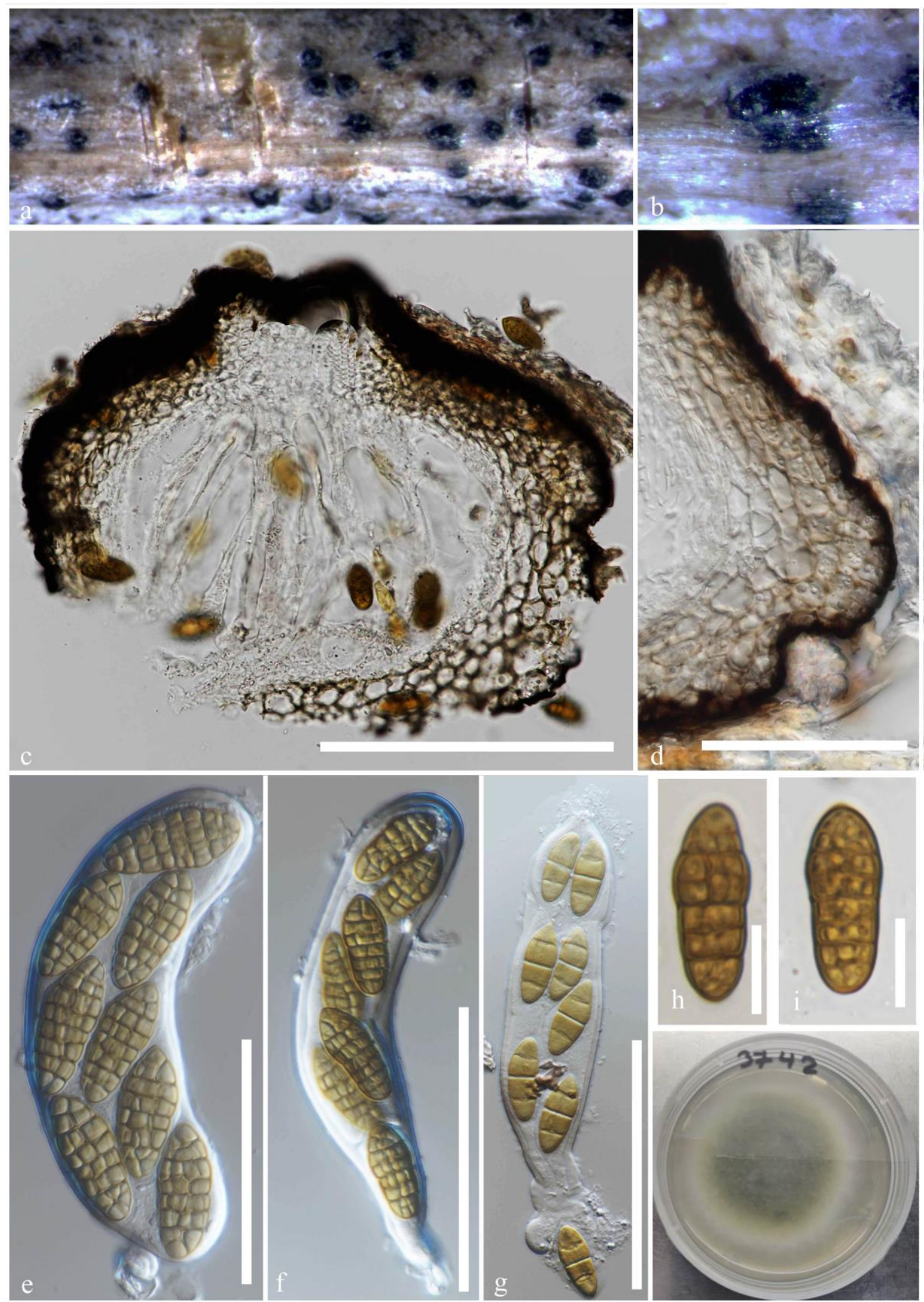

Figure 27 - Stemphylium artemisiae (MFLU 20-0404, holotype). a, b Ascomata on host surface. c Vertical section through an ascoma. d Peridium. e-g Asci. h, i Ascospores. j Culture on PDA. Scale bars: $\mathrm{a}=500 \mu \mathrm{m}, \mathrm{h}, \mathrm{i}=50 \mu \mathrm{m}, \mathrm{g}-\mathrm{i}=10 \mu \mathrm{m}$. 

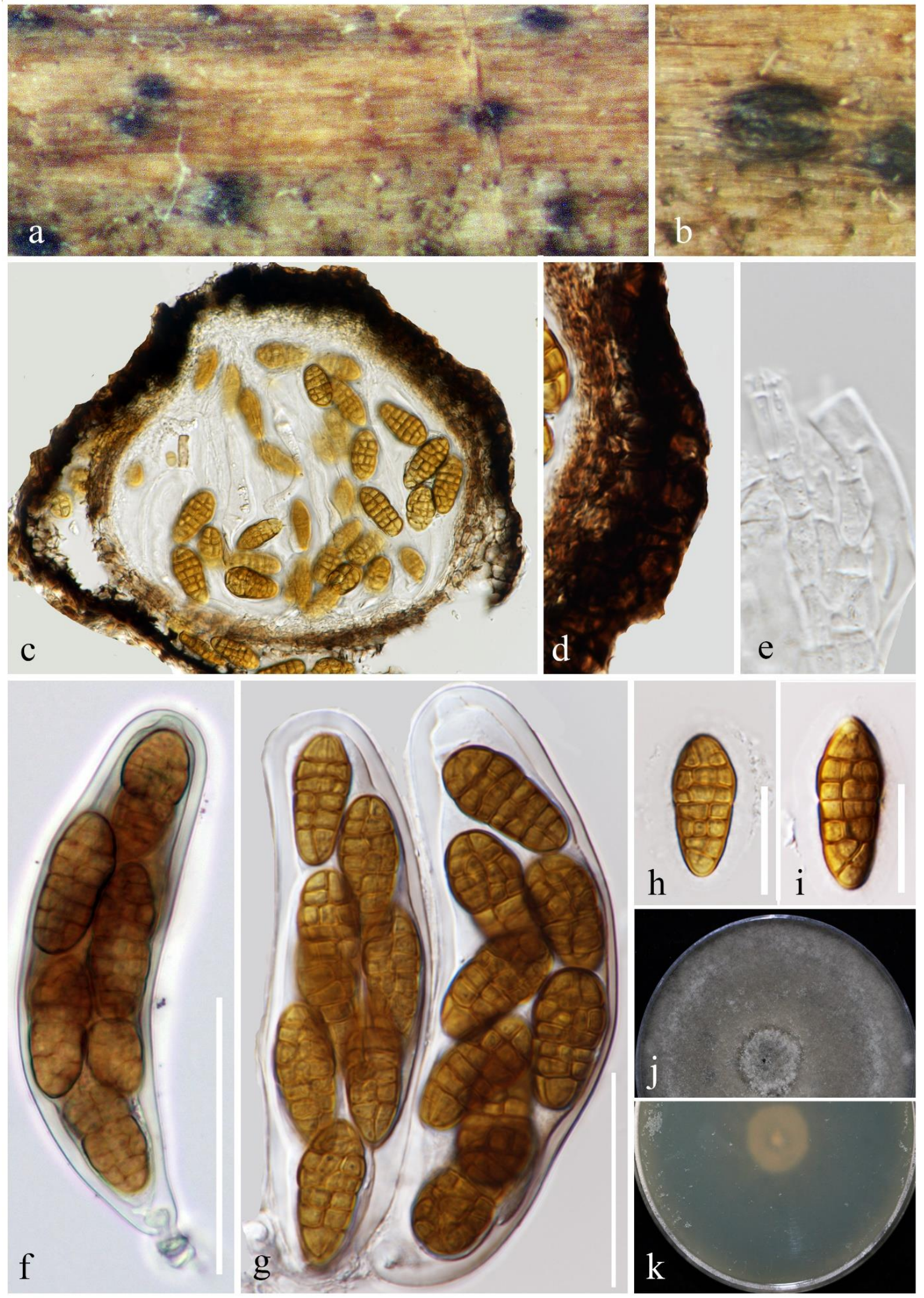

Figure 28 - Stemphylium vesicarium (MFLU 20-0405). a, b Ascomata on host surface. c Vertical section through an ascoma. d Peridium. e Pseudoparaphyses. f, g Asci. h, i Ascospores. j, k Culture on PDA (j upper, $\mathrm{k}$ lower). Scale bars: $\mathrm{a}=500 \mu \mathrm{m}, \mathrm{c}-\mathrm{f}=50 \mu \mathrm{m}, \mathrm{g}-\mathrm{i}=20 \mu \mathrm{m}$.

Culture characteristics - Colonies on PDA reaching $6 \mathrm{~cm}$ diam. after 1 weeks at $24^{\circ} \mathrm{C}$, later with dense mycelium, circular, smooth margin, grey from upper, reverse brownish yellow. 
Material examined - ITALY, Province of Forlì-Cesena, Isola Santa Sofia, on a dead aerial stem of Dianthus sp. (Caryophyllaceae), 2 April 2018, E. Camporesi, IT 2461 (MFLU 20-0405; JZBH3240017), living culture JZB3240017; ibids., Cusercoli-Civitella di Romagna, on dead aerial stem of Tragopogon sp. (Asteraceae), 14 April 2018, E. Camporesi, IT 3833 (MFLU 20-0406; JZBH3240018); Cusercoli-Civitella di Romagna, dead aerial stem of Scrophularia canina (Scrophulariaceae), 8 May 2018, E. Camporesi, IT 1433 (MFLU 20-0407; JZBH3240019); on dead aerial stem of Onobrychis viciifolia (Fabaceae), 21 April 2018, E. Camporesi, IT 3835 (MFLU 200408; JZBH3240020); Via Cerchia-Forlì, on dead aerial stem of Torilis arvensis (Apiaceae), 1 March 2018, E. Camporesi, 3748 (MFLU 20-0409); Castiglione-Forlì, on dead aerial stem of Vincetoxicum hirundinaria (Apocynaceae), 12 July 2018, E. Camporesi, IT 3972 (MFLU 20-0410; JZBH3240022); Ridracoli - Bagno di Romagna on dead aerial stem of Helleborus sp. (Ranunculaceae), 5 April 2018, E. Camporesi, IT 3819 (MFLU 20-0411; JZBH3240023).

GenBank Accessions - (MFLU 20-0405) ITS: MT370403; CAL: MT729657; GAPDH: MT729659, (MFLU 20-0406) ITS: MT370406; CAL: MT729655; GAPDH: MT729662, (MFLU 20-0407) ITS: MT370402; GAPDH: MT729658, (MFLU 20-0408) ITS: MT370407; GAPDH: MT729660, (MFLU 20-0409) ITS: MT370404; CAL: MT729653; (MFLU 20-0410) ITS: MT370408; CAL: MT729656; GAPDH: MT729663, (MFLU 20-0411) ITS: MT370405; CAL: MT729654; GAPDH: MT729661

Notes - Stemphylium vesicarium is widely known as a plant pathogenic fungus and causes leaf spots on a wide range of plant species mostly on Allium spp. (Woudenberg et al. 2017). This study reports new host records on Helleborus sp., Onobrychis viciifolia, Scabiosa sp., Scrophularia canina, Torilis arvensis, Tragopogon sp. and Vincetoxicum hirundinaria from Italy. According to Farr \& Rossman (2020), this species is associated with more than 20 plant species worldwide.

\section{Acknowledgments}

We would like to thank Thailand Research grants entitled Impact of climate change on fungal diversity and biogeography in the Greater Mekong Subregion (grant no: RDG6130001) and (grant no: TRG5880152). We are grateful to the Mushroom Research Foundation for supporting this research. D.N. Wanasinghe would like to thank the National Science Foundation of China and the Chinese Academy of Sciences for financial support under the following grants: 41761144055, 41771063 and Y4ZK111B01. We also acknowledge the Mushroom Research Foundation for partially supporting this research. Rashika Brahmanage offers his deepest gratitude to Dr. Ruvishika Jayawardena, L. Mei and Zhang Wei for their helpful comments and advices.

\section{References}

Al Ghafri AB, Maharachchikumbura SS, Hyde KD, Al-Saady NA, Al-Sadi AM. 2019 - A new section and a new species of Alternaria encountered from Oman. Phytotaxa 405, 279-89.

Al-Nadabi HH, Maharachchikumbura SS, Agrama H, Al-Azri M et al. 2018 - Molecular characterization and pathogenicity of Alternaria species on wheat and date palms in Oman. European journal of plant pathology 152, 577-88.

Andersen B, Hollensted M. 2008 - Metabolite production by different Ulocladium species. International journal of food microbiology. 126, 172-9.

Ariyawansa HA, Hyde KD, Jayasiri SC, Buyck B et al. 2015a - Fungal diversity notes 111-252 taxonomic and phylogenetic contributions to fungal taxa. Fungal Diversity 75, 27-274.

Ariyawansa HA, Phookamsak R, Tibpromma S, Kang JC, Hyde KD. 2014 - A molecular and morphological reassessment of Diademaceae. The Scientific World Journal.

Doi: $10.1155 / 2014 / 675348$

Ariyawansa HA, Phukhamsakda C, Thambugala KM, Bulgakov TS et al. 2015b - Revision and phylogeny of Leptosphaeriaceae. Fungal Diversity 74(1), 19-51.

Ariyawansa HA, Thambugala KM, Manamgoda DS, Jayawardena R et al. 2015c - Towards a natural classification and backbone tree for Pleosporaceae. Fungal Diversity 71(1), 85-139. 
Arx JA von, Müller E. 1975 - A re-evaluation of the bitunicate ascomycetes with keys to families and genera. Studies in Mycology 9, 1-159.

Aveling TAS, Snyman HG. 1993 - Infection studies of Stemphylium vesicarium on onion leaves. Mycological Research 97, 984-988.

Aveskamp MM, De Gruyter J, Crous PW. 2008 - Biology and recent developments in the systematics of Phoma, a complex genus of major quarantine significance. Fungal Diversity 31, 1-18.

Bakhshi M, Arzanlou M, Zare R, Groenewald JZ, Crous PW. 2019 - New species of Septoria associated with leaf spot diseases in Iran. Mycologia 1116, 1056-1071.

Barr ME. 1987a - Prodromus to class Loculoascomyctes. Published by the author, Amherst, MA. 168 pp. 1991. Notes on and additions to North American members of the Herpotrichiellaceae. Mycotaxon 41, 419-436.

Barr ME. 1987b - Prodomus to class Loculoascomycetes. Newell, Amherst

Barr ME. 1979 - A classification of Loculoascomycetes. Mycologia 71, 935-957.

Barr ME. 1990 - Melanommatales (Loculoascomycetes). N Am Flora Ser II 13, 1-129.

Bennett S. 1983 - Log-logistic regression models for survival data. Journal of the Royal Statistical Society: Series C (Applied Statistics) 32, 165-71.

Berbee ML, Pirseyedi M, Hubbard S. 1999 - Cochliobolus phylogenetics and the origin of known, highly virulent pathogens, inferred from ITS and glyceraldehyde-3-phosphate dehydrogenase gene sequences. Mycologia 91, 964-977.

Boehm EW, Schoch CL, Spatafora JW. 2009a - On the evolution of the Hysteriaceae and Mytilinidiaceae (Pleosporomycetidae, Dothideomycetes, Ascomycota) using four nuclear genes. Mycological Research 113, 461-479.

Boehm EWA, Mugambi G, Miller AN, Huhndorf S et al. 2009b - A molecular phylogenetic reappraisal of the Hysteriaceae, (Pleosporomycetidae, Dothideomycetes) with keysto world Mytilinidiaceae and Gloniaceaespecies. Studies of Mycology 64, 49-83.

Boerema GH. 2004 - Phoma identification manual: differentiation of specific and infra-specific taxa in culture. CABI

Boerema GH, Van Kesteren HA. 1964 - The nomenclature of two fungi parasitizing Brassica. Persoonia 3, 17-28.

Brahmanage RS, Lu YZ, Bhat DJ, Wanasinghe DN et al. 2017 - Phylogenetic investigations on freshwater fungi in Tubeufiaceae (Tubeufiales) reveals the new genus Dictyospora and new species Chlamydotubeufia aquatica and Helicosporium flavum Mycosphere 8, 917-933.

Brahmanage RS, Hyde KD, Li XH, Jayawardena RS et al. 2018 - Are pathogenic isolates of Stemphylium host specific and cosmopolitan? Plant Pathology \& Quarantine 8, 153-164.

Brahmanage RS, Wanasinghe DN, Dayarathne MC, Jeewon R et al. 2019 - Morphology and phylogeny reveal Stemphylium dianthi sp. nov. and new host records for the sexual morphs of $S$. beticola, $S$. gracilariae, $S$. simmonsii and $S$. vesicarium from Italy and Russia. Phytotaxa 411, 243-263.

Cai L, Tsui CK, Zhang KQ, Hyde KD. 2002 - Aquatic fungi from Lake Fuxian, Yunnan, China. Fungal Diversity 9, 57-70.

Cai L, Zhang K, McKenzie EHC, Hyde KD. 2003 - Freshwater fungi from bamboo and wood submerged in the Liput River in the Philippines. Fungal Diversity 13, 1-12.

Câmara MPS, O’Neill NR, van Berkum P. 2002 - Phylogeny of Stemphylium spp. based on ITS and glyceraldehyde-3-phosphate dehydrogenase gene sequences. Mycologia 94, 660-672.

Cannon PF, Kirk PM. 2007 - Fungal families of the world, $7^{\text {th }}$ edn. CAB International, Wallingford

Carbone I, Kohn LM. 1999 - A method for designing primer sets for speciation studies in filamentous ascomycetes. Mycologia 91, 553-556.

Carson ML. 2005 - Yield loss potential of Phaeosphaeria leaf spot of maize caused by Phaeosphaeria maydis in the United States. Plant Disease 89, 986-988.

Chen Q, Zhang KE, Zhang GU, Cai L. 2015 - A polyphasic approach to characterize two novel species of Phoma (Didymellaceae) from China. Phytotaxa 197, 267-81. 
Chomnunti P, Hongsanan S, Aguirre-Hudson B, Tian Q, Peršoh D et al. 2014 - The sooty moulds. Fungal Diversity 66, 1-36.

Costa EO, Gandra CR, Pires MF, Couthino SD et al. 1993 - Survey of bovine mycotic mastitis in dairy herds in the State of São Paulo, Brazil. Mycopathologia 124, 13-17.

Dai DQ, Bahkali AH, Li WJ, Bhat DJ et al. 2015 - Bambusicola loculata sp. nov. (Bambusicolaceae) from bamboo. Phytotaxa 213(2), 122-130.

Dai D, Bhat DJ, Liu J, Chukeatirote E et al. 2012 - Bambusicola, a new genus from bamboo with asexual and sexual morphs. Cryptogamie Mycologie 33(3), 363-79.

Dayarathne MC, Boonmee S, Braun U, Crous PW et al. 2016 - Taxonomic utility of old names in current fungal classification and nomenclature: Conflicts, confusion \& clarifications. Mycosphere 7, 1622-1648.

Dayarathne MC, Phookamsak R, Ariyawansa HA, Jones EBG et al. 2015 - Phylogenetic and morphological appraisal of Leptosphaeria italica sp. nov. (Leptosphaeriaceae, Pleosporales) from Italy. Mycosphere 6, 634-642.

Dayarathne MC, Jones EBG, Maharachchikumbura SSN, Devadatha B et al. 2020 - Morphomolecular characterization of microfungi associated with marine based habitats. Mycosphere $11,1-188$.

De Gruyter J, Woudenberg JH, Aveskamp MM, Verkley GJ et al. 2013 - Redisposition of Phomalike anamorphs in Pleosporales. Studies in Mycology 75, 1- 36.

De Hoog GS, Guarro J, Gené J, Figueras MJ. 2000 - Atlas of clinical fungi. Centraalbureau voor Schimmelcultures (CBS).

Devadatha B, Sarma VV, Jeewon R, Hyde KD, Jones EBG. 2018 - Morosphaeria muthupetensis sp. nov. (Morosphaeriaceae) from India: Morphological characterisation and multigene phylogenetic inference. Botanica Marina 61, 395-405.

Ellis MB. 1971 - Dematiaceous hyphomycetes. Dematiaceous hyphomycetes. Commonwealth Mycological Institute, Commonwealth Mycological Institute, UK, pp. 608.

Ellis MB, Gibson IA. 1975 - Stemphylium lycopersici. [Descriptions of Fungi and Bacteria]. IMI Descriptions of Fungi and Bacteria 127, 1261-1270.

Ellis MA, Sinclair JB. 1976 - Effect of benomyl field sprays on internally-borne fungi, germination, and emergence of late-harvested soybean seeds. Phytopathology 66, 680-2.

Enjoji S. 1931 - Two diseases of tomato (2) (in Japanese). Journal of Plant Protection Research 18, $48-53$.

Eriksson OE, Hawksworth DL. 2003 - Saccharicola, a new genus for two Leptosphaeria species on sugar cane. Mycologia 95, 426-33.

Faisal M, Elsayed E, Fitzgerald SD, Silva V, Mendoza L. 2007 - Outbreaks of phaeohyphomycosis in the chinook salmon (Oncorhynchus tshawytscha) caused by Phoma herbarum. Mycopathologia 163, 41.

Falloon PG, Falloon LM, Grogan RG. 1987 - Etiology and epidemiology of Stemphylium leaf spot and purple spot of asparagus in California. Phytopathology 77, 407-413

Farr DF, Rossman AY. 2020 - Fungal databases, systematic mycology and microbiology laboratory, ARS, USDA. Retrieved January 6, 2020, from http://nt.arsgrin.gov/fungaldatabases.

Gálvez L, Gil-Serna J, García M, Iglesias C, Palmero D. 2016 - Stemphylium leaf blight of garlic (Allium sativum) in Spain: taxonomy and in vitro fungicide response. The Plant Pathology Journal 32, 388-395.

Glass NL, Donaldson GC. 1995 - Development of primer sets designed for use with the PCR to amplify conserved genes from filamentous ascomycetes. Applied and Environmental Microbiology 61, 1323-1330.

Ghaderi F, Razavi M. 2018 - Identification of the species Parastagonospora dactylidis on poaceous plants in Iran. Mycologia Iranica 35-41.

Hall TA. 1999 - BioEdit: a user-friendly biological sequence alignment editor and analysis program for Windows 95/98/NT. Nucleic Acids Symposium Series 41, 95-98. 
Han JH, Shin JH, Fu T, Kim KS. 2019 - A new record and characterization of asparagus purple spot caused by Stemphylium vesicarium in Korea. Mycobiology 2, 120-5.

Hanse B. 2013 - Research on Stemphylium spp. the causal agent of the yellow leaf spot disease in sugar beet in 2012. IRS, Bergen op Zoom, The Netherlands.

Hashimoto A, Hirayama K, Takahashi H, Matsumura M et al. 2018 - Resolving the Lophiostoma bipolare complex: Generic delimitations within Lophiostomataceae. Studies in Mycology 90, 161-189.

Hawksworth DL. 2004 - Lichenoconium christiansenii sp. nov. from Nodobryoria abbreviata (Parmeliaceae) in the Pacific Northwest, with a key to the known lichenicolous species. The Lichenologist 36, 1-6.

Heidari K, Mehrabi-Koushki M, Farokhinejad R. 2018 - Curvularia mosaddeghii sp. nov., a novel species from the family Pleosporaceae. Mycosphere 9, 635-46.

Höhnel FV. 1919 - Fragmente zur Mykologie XXIII. Sitzungsber Akad Wiss Wien, MathNaturwiss Kl, Abt. 1, 535-625.

Hongsanan S, Hyde KD, Phookamsak R, Boonmee S et al. 2020 - Refined families of Dothideomycetes. Fungal diversity (in press)

Huelsenbeck JP, Ronquist F. 2001 - MRBAYES: Bayesian inference of phylogenetic trees. Bioinformatics 17, 754-755.

Hyde KD. 1991 - A new amphisphaeriaceous fungus from interdial fronds of Nypa fruticans. Transactions of the Mycological Society of Japan 32, 265-271.

Hyde KD, Chaiwan N, Norphanphoun C, Boonmee S et al. 2018 - Mycosphere notes 169-224. Mycosphere 9, 271-430

Hyde KD, Dong Y, Phookamsak R, Jeewon R et al. 2020 - Fungal diversity notes 1151-1276: taxonomic and phylogenetic contributions on genera and species of fungal taxa. Fungal Diversity 1-273.

Hyde KD, Fröhlich J, Taylor JE. 1998 - Fungi from palms. XXXVI. Reflections on unitunicate ascomycetes with apiospores. Sydowia 50, 21-80.

Hyde KD, Hongsanan S, Jeewon R, Bhat DJ et al. 2016 - Fungal diversity notes 367-490: taxonomic and phylogenetic contributions to fungal taxa. Fungal Diversity 80, 1-270.

Hyde KD, Jones EBG, Liu JK, Ariyawansa HA et al. 2013 - Families of Dothideomycetes. Fungal Diversity 63, 1-313.

Hyde KD, Norphanphoun C, Bazzicalupo A, Karunarathna A et al. 2017 - Fungal diversity notes 603 - 708: Taxonomic and phylogenetic notes on genera and species. Fungal Diversity 87, 1235.

Hyde KD, Norphanphoun C, Chen J, Dissanayake AJ et al. 2018 - Thailand's amazing diversity: up to $96 \%$ of fungi in northern Thailand may be novel. Fungal Diversity 93, 215-239.

Ichikawa K, Sato T. 1994 - Leaf and stem spot of aster caused by Stemphylium vesicarium (in Japanese with English summary). Annals of the Phytopathological Society of Japan 60, 523.

Irwin JAG. 1984 - Etiology of a new Stemphylium-incited leaf disease of alfalfa in Australia. Plant Disease 68, 531-532.

Jaklitsch WM, Checa J, Blanco MN, Olariaga I et al. 2018 - A preliminary account of the Cucurbitariaceae. Studies in mycology. 90, 71-118.

Jaklitsch WM, Voglmayr H. 2016 - Hidden diversity in Thyridaria and a new circumscription of the Thyridariaceae. Studies in Mycology 85, 35-64.

Jayasiri SC, Hyde KD, Ariyawansa HA, Bhat J et al. 2015 - The Faces of Fungi database: fungal names linked with morphology, phylogeny and human impacts. Fungal Diversity 74, 3-18.

Jayasiri SC, Hyde KD, Jones EBG, McKenzie EHC et al. 2019 - Diversity, morphology and molecular phylogeny of Dothideomycetes on decaying wild seed pods and fruits. Mycosphere $10,1-186$.

Jayawardena RS, Hyde KD, Mckenzie EHC, Jeewon R et al. 2019a - One stop shop III: taxonomic update with molecular phylogeny for important phytopathogenic genera: 51-75. Fungal Diversity 98, 77-160. 
Jayawardena RS, Hyde KD, Jeewon R, Ghobad-Nejhad M et al 2019b - One stop shop II: taxonomic update with molecular phylogeny for important phytopathogenic genera: 26-50. Fungal Diversity 94, 41-129.

Jeewon R, Hyde KD. 2016 - Establishing species boundaries and new taxa among fungi: recommendations to resolve taxonomic ambiguities. Mycosphere 7, 1669-1677.

Jeewon R, Ittoo J, Mahadeb D, Jaufeerally-Fakim Y et al. 2013 - DNA based identification and phylogenetic characterisation of endophytic and saprobic fungi from Antidesma madagascariense, a medicinal plant in Mauritius. Journal of Mycology. Doi: 10.1155/2013/781914

Jeewon R, Wanasinghe DN, Rampadaruth S, Puchooa D et al. 2017 - Nomenclatural and identification pitfalls of endophytic mycota based on DNA sequence analyses of ribosomal and protein genes phylogenetic markers: A taxonomic dead end? Mycosphere 8, 1802-1817

Johnson DA, Lunden JD. 1986 - Effects of wounding and wetting duration on infection of asparagus by Stemphylium vesicarium. Plant Disease 70, 419-420.

Jones EBG, Suetrong S, Sakayaroj J, Bahkali AH et al. 2015 - Classification of marine Ascomycota, Basidiomycota, Blastocladiomycota and Chytridiomycota. Fungal Diversity 73, $1-72$.

Jones EBG, Pang KL, Abdel-Wahab MA, Scholz B et al. 2019 - An online resource for marine fungi. Fungal Diversity 96, 347-433.

Katoh K, Rozewicki J, Yamada KD. 2019 - MAFFT online service: multiple sequence alignment, interactive sequence choice and visualization. Briefings in bioinformatics 20, 1160-1166.

Kodsueb R, Dhanasekaran V, Aptroot A, Lumyong S et al. 2006 - The family Pleosporaceae: intergeneric relationships and phylogenetic perspectives based on sequence analyses of partial 28S rDNA. Mycologia 98, 571-583.

Köhl J, Groenenboom-de Haas B, Goossen-van de Geijn H, Speksnijder A et al. 2009 Pathogenicity of Stemphylium vesicarium from different hosts causing brown spot in pear. European Journal of Plant Pathology 124, 151

Kohlmeyer J, Volkmann-Kohlmeyer B. 1991 - Illustrated key to the filamentous higher marine fungi. Botanica Marina 34, 1-61.

Kohlmeyer J. 1969 - Marine fungi of Hawaii including the new genus Helicascus. Canadian Journal of Botany 9, 1469-87.

Kruys Å, Eriksson OE, Wedin M. 2006 - Phylogenetic relationships of coprophilous Pleosporales (Dothideomycetes, Ascomycota), and the classification of some bitunicate taxa of unknown position. Mycological research 110, 527-536.

Kurose D, Kanegae Y, Misawa T, Ebihara Y. 2015 - Yellow spot of white lace flower caused by Pleospora herbarum in Japan. Japanese Journal of Phytopathology 81, 169-172.

Lamprecht SC, Baxter A, Thompson AH. 1984 - Stemphylium vesicarium on Medicago spp. In South Africa. Phytophylactica 16, 73-75.

Lawrence DP, Rotondo F, Gannibal PB. 2016 - Biodiversity and taxonomy of the pleomorphic genus Alternaria. Mycological progress 15, 1-22.

Li JF, Phookamsak R, Jeewon R, Darbhe J et al. 2017 - Molecular taxonomy and morphological characterization reveal new species and new host records of Torula species (Torulaceae, Pleosporales). Mycological progress 16, 447-461.

Li WJ, Bhat DJ, Camporesi E, Tian Q et al. 2015a - New asexual morph taxa in Phaeosphaeriaceae. Mycosphere 6, 681-708.

Li WJ, McKenzie EHC, Liu JK, Bhat J et al. 2020 - Taxonomy and phylogeny of hyaline-spored coelomycetes. Fungal Diversity 100, 1-523.

Liew ECY, Aptroot A, Hyde KD. 2000 - Phylogenetic significance of the pseudoparaphyses in Loculoascomycete taxonomy. Molecular Phylogeny \& Evolution 16: 392-402.

Liu JK, Hyde KD, Jeewon R, Phillips AJ et al. 2017 - Ranking higher taxa using divergence times: a case study in Dothideomycetes. Fungal Diversity 84, 75-99. 
Liu JK, Hyde KD, Jones EBG, Ariyawansa HA et al. 2015 - Fungal diversity notes 1-110: taxonomic and phylogenetic contributions to fungal species. Fungal diversity 72, 1-197.

Liu YJ, Whelen S, Hall BD. 1999 - Phylogenetic relationships among ascomycetes: evidence from an RNA polymerase II subunit. Molecular Biology and Evolution 16, 1799-1808.

Llorente I, Montesinos E. 2006 - Brown spot of pear: an emerging disease of economic importance in Europe. Plant Disease 90, 1368-1375.

Lugauskas A, Levinskait L, Pečiulyt D. 2003 - Micromycetes as deterioration agents of polymeric materials. International biodeterioration \& biodegradation 52, 233-42.

Lumbsch HT, Huhndorf SM. 2007 - Outline of Ascomycota. Myconet 13, 1-99.

Luo ZL, Bao DF, Bhat JD, Yang J et al. 2016 - Sporoschisma from submerged wood in Yunnan, China. Mycological progress 15, 1145-1155.

Luo ZL, Bhat DJ, Jeewon R, Boonmee S, Bao DF et al. 2017 - Molecular phylogeny and morphological characterization of asexual fungi (Tubeufiaceae) from freshwater habitats in Yunnan, China. Cryptogamie, Mycologie 38, 27-53.

Luo ZL, Hyde KD, Liu JK, Bhat DJ et al. 2018 - Lignicolous freshwater fungi from China II: Novel Distoseptispora (Distoseptisporaceae) species from northwestern Yunnan Province and a suggested unified method for studying lignicolous freshwater fungi. Mycosphere 9, 444-461.

Luttrell ES. 1955 - A taxonomic revision of Helminthosporium sativum and related species. American Journal of Botany 42(1), 57-68.

Maharachchikumbura SS, Ariyawansa HA, Wanasinghe DN, Dayarathne MC et al. 2019 Phylogenetic classification and generic delineation of Hydeomyces desertipleosporoides gen. et sp. nov., (Phaeosphaeriaceae) from Jebel Akhdar Mountain in Oman. Phytotaxa, 391, 2838.

Marin-Felix Y, Margarita HR, Michael J, Wingfield A et al. 2019 - Genera of phytopathogenic fungi GOPHY 2. Studies in mycology 92, 47-133.

Miller ME, Taber RA, Amador JM. 1978 - Stemphylium blight of onion in South Texas. Plant Disease Reporter 62, 851-853.

Misawa T. 2009 - Brown leaf blight of Chinese chive caused by Stemphylium botryosum Wallroth. (Abstract in Japanese). Japanese Journal of Phytopathology 75-87.

Mugambi GK, Huhndorf SM. 2009 - Molecular phylogenetics of Pleosporales: Melanommataceae and Lophiostomataceae recircumscribed (Pleosporomycetidae, Dothideomycetes, Ascomycota). Studies in Mycology 64, 103-121.

Munk A. 1953 - The system of the Pyrenomycetes. A contribution to a natural classification of the group Sphaeriales sensu Lindau. Dansk Botanisk Arkiv 15, 1-163.

Munk A. 1956 - On Metasphaeria coccodes (Karst.) Sacc. and other fungi probably related to Massarina Sacc. Massarinaceae n. fam. Friesia 5, 303-308.

Munk A. 1957 - Danish Pyrenomycetes. Dan Bot Ark 17, 1-491.

Nasehi A, Kadir JB, Esfahani MN, Mahmodi F. 2013 - An outbreak of leaf spot caused by Stemphylium solani on eggplant in Malaysia. Plant Disease 97, 689.

Nees von Esenbeck CG. 1816 - Das system der pilze und schwämme. Würzburg: Stahelsche Buchhandlung 17.

Nitschke TR. 1869 - Pleosporaceae. Verh. Naturhist. Ver Preuss Rheinl. 26, 74.

Nylander JA, Ronquist F, Huelsenbeck JP, Nieves-Aldrey J. 2004 - Bayesian phylogenetic analysis of combined data. Systematic biology 53, 47-67.

O’Donnell K, Cigelnik E. 1997 - Two divergent intragenomic rDNA ITS2 types within a monophyletic lineage of the fungus Fusarium are non orthologous. Molecular phylogenetics and evolution 7(1), 103-116.

Osterhage C, Schwibbe M, König GM, Wright AD. 2000 - Differences between marine and terrestrial Phoma species as determined by HPLC-DAD and HPLC-MS. Phytochemical analysis 11, 288-294. 
Pedras MSC, Biesenthal CJ. 2000 - HPLC - analyses of cultures of Phoma species: differentiation among groups and species through secondary metabolite profiles. Canadian Journal of Microbiology 46, 685-691.

Pem D, Hongsanan S, Doilom M, Tibpromma S et al. 2019 - https://www.dothideomycetes.org: An online taxonomic resource for the classification, identification, and nomenclature of Dothideomycetes. Asian Journal of Mycology 2, 287-297

Phookamsak R, Hyde KD, Jeewon R, Bhat DJ et al. 2019 - Fungal diversity notes 929-1035: taxonomic and phylogenetic contributions on genera and species of fungi. Fungal Divers 95, $1-273$.

Phookamsak R, Liu JK, McKenzie EH, Manamgoda DS et al. 2014 - Revision of Phaeosphaeriaceae. Fungal Diversity 68, 159-238.

Phookamsak R, Manamgoda DS, Li WJ. 2015 - Poaceascoma helicoides gen et sp. nov., a new genus with scolecospores in Lentitheciaceae. Cryptogamie Mycologie 36, 225-236.

Phookamsak R, Wanasinghe DN, Hongsanan S, Phukhamsakda C. 2017 - Towards a natural classification of Ophiobolus and ophiobolus-like taxa; introducing three novel genera Ophiobolopsis, Paraophiobolus and Pseudoophiobolus in Phaeosphaeriaceae (Pleosporales). Fungal Diversity 87, 299-339.

Pinnoi A, Jeewon R, Sakayaroj J, Hyde KD, Jones EBG. 2007 - Berkleasmium crunisia sp. nov. and its teleomorphic affinities to the Pleosporales based on 18S, 28S and ITS-5.8S rDNA sequence analyses. Mycologia 99, 378-384.

Pitt JI, Hocking AD. 1997 - Fungi and food spoilage (vol. II). Eds. Pitt, JI. and Hocking, AD. Blackie Academic and Professional, London.

Poursafar A, Ghosta Y, Orina AS, Gannibal PB. 2018 - Taxonomic study on Alternaria sections Infectoriae and Pseudoalternaria associated with black (sooty) head mold of wheat and barley in Iran. Mycological Progress 17, 343- 56.

Preedanon S, Klaysuban A, Suetrong S, Promchoo W. 2017 - Helicascus mangrovei sp. nov., a new intertidal mangrove fungus from Thailand. Mycoscience 58,174-80.

Preuss CGT. 1851 - Übersicht untersuchter Pilze, besonders aus der Umgegend von Hoyerswerda. Linnaea 24, 99-153.

Promputtha I, Lumyong S, Vijaykrishna D, McKenzie EHC et al. 2007 - A phylogenetic evaluation of whether endophytes become saprotrophs at host senescence. Microbial Ecology 53, 579590.

Quaedvlieg W, Verkley GJM, Shin HD, Barretto RW. 2013 - Sizing up Septoria. Studies in Mycology 75, 307-390.

Rabie CJ, Rensburg SJV, Watt JJV, Lubben A. 1975 - Onyalai the possible involvement of a mycotoxin produced by Phoma sorghina in the aetiology. South African Medical Journal 57, 1647-1650.

Rai M, Deshmukh P, Gade A, Ingle A et al. 2009 - Phoma Saccardo: Distribution, secondary metabolite production and biotechnological applications Critical Reviews in Microbiology $35,182-196$.

Rambaut A. 2012 - Fig.Tree. Tree Fig. Drawing Tool, v. 1.4.0

Ramesh LC, Rao GP, Manoharachari C, Bhat DJ. 2003 - International Book Distributing Company, Lucknow, Frontiers of Fungal Diversity 457-479.

Rannala B, Yang Z. 1996 - Probability distribution of molecular evolutionary trees: a new method of phylogenetic inference. Journal of Molecular Evolution 43, 304-311.

Rehner S, Samuels GJ. 1994 - Taxonomy and phylogeny of Gliocladium analyzed from nuclear large subunits ribosomal DNA sequences. Mycological Research 98, 625-634.

Reis A, Boiteux LS, Fonseca MN. 2011 - Identification of solanaceous and nonsolanaceous species as hosts of Stemphylium solani isolates in Brazil. Phytopathology 101-152.

Reiss MLC. 1854 - Neue Kernpilze. Hedwigia 1, 23-28.

Ronquist F, Huelsenbeck JP. 2003 - MrBayes 3: Bayesian phylogenetic inference under mixed models. Bioinformatics 19, 1572-1574. 
Roberts RG. 2007 - Two new species of Alternaria from pear fruit. Mycotaxon 100, 159-67.

Runa F, Park MS, Pryor BM. 2009 - Ulocladium systematics revisited: phylogeny and taxonomic status. Mycological progress 1, 8-35.

Saccardo PA. 1883 - Pyrenomyceteae. Sylloge Fungorum Omnium Hucusque Cognitorum 2, 1813.

Schoch CL, Crous PW, Groenewald JZ, Boehm EWA et al. 2009 - A class-wide phylogenetic assessment of Dothideomycetes. Studies in Mycology 64, 1-15.

Seaney RR. 1973 - Birdsfoot trefoil. In: Heath ME, Metcalfe DS, Barnes RF (eds). Forages the science of grassland agriculture. Ames, Iowa, The Iowa State University Press. 177-188.

Shearer CA, Raja HA, Miller AN, Nelson P et al. 2009 - The molecular phylogeny of freshwater Dothideomycetes. Studies of Mycology 64, 145-153.

Sheridan JE, Soteros JJ. 1974 - A survey of fungi in jet aircraft fuel systems in New Zealand. survey of fungi in jet aircraft fuel systems in New Zealand. International biodeterioration bulletin 10, 105-107.

Shibata S, Horiuchi S, Satou M, Yamauchi N. 2000 - Stemphylium vesicarium, another causal agent of leaf blight of welsh onion in Japan (in Japanese with English summary). Annual Report of the Society of Plant Protection of North Japan 51, 62-65.

Shoemaker RA, Babcock CE. 1989 - Phaeosphaeria. Canadian Journal of Botany 67, 1500-1599.

Shoemaker RA, Babcock CE. 1992 - Planodictyosporous Pleosporales: Clathrospora, Comoclathris, Graphyllium, Macrospora, and Platysporoides. Canadian Journal of Botany 70, 1617-1658.

Silvestro D, Michalak I. 2012 - raxmlGUI: a graphical front-end for RAxML. Organisms Diversity \& Evolution. 12, 335-7.

Simmons EG. 1967 - Typification of Alternaria, Stemphylium, and Ulocladium. Mycologia, 59(1), 67-92.

Simmons EG, Stuteville DL, Erwin DC. 1990 - Stemphylium leaf spot. Causal organisms. Compendium of alfalfa diseases, 2nd ed. St. Paul, Minnesota: APS Press. 84.

Sivanesan A. 1984 - Acantharia, Gibbera and their anamorphs. Transactions of the British Mycological Society 82, 507-29.

Sørensen Annette, Peter SL, Mette L, Kristian FN et al. 2011 - Frisvad. Aspergillus saccharolyticus sp. nov., a black Aspergillus species isolated in Denmark. International journal of systematic and evolutionary microbiology 61, 3077-3083.

Stukenbrock EH, Banke S, McDonald BA. 2006 - Global migration patterns in the fungal wheat pathogen Phaeosphaeria nodorum. Molecular Ecology 15, 2895-2904.

Subedi S, Shrestha SM, Bahadur G, Thapa RB et al. 2014 - Integrated Approach for the Management of New Threat Stemphylium botryosum walr Causing Blight of Lentil (Lens culinaris Medik). Türk Tarım ve Doğa Bilimleri 6, 1209-1220.

Suetrong S, Schoch CL, Spatafora JW, Kohlmeyer J et al. 2009 - Molecular systematics of the marine Dothideomycetes. Studies in Mycology 64, 155-173.

Sun JZ, Liu XZ, McKenzie EHC, Jeewon R et al. 2019 - Fungicolous fungi: terminology, diversity, distribution, evolution, and species checklist. Fungal Diversity 95, 337-430.

Suzui T. 1973 - Stemphylium leaf spot (Stemphylium botryosum Wallr.) on asparagus plants (in Japanese with English summary). Annals of the Phytopathological Society of Japan 39, 364366.

Tamura K, Stecher G, Peterson D, Filipski A, Kumar S. 2013 - MEGA6: Molecular Evolutionary Genetics Analysis version 6.0. Molecular Biology and Evolution 30, 2725-2729

Tennakoon DS, Phookamsak R, Wanasinghe DN, Yang JB et al. 2017 - Morphological and phylogenetic insights resolve Plenodomus sinensis (Leptosphaeriaceae) as a new species. Phytotaxa 324(1), 73-82.

Tanaka K, Hirayama K, Yonezawa H, Hatakeyama S et al. 2009 - Molecular taxonomy of bambusicolous fungi: Tetraplosphaeriaceae, a new pleosporalean family with Tetraploa-like anamorphs. Studies in mycology 64, 175-209. 
Tanaka K, Hirayama K, Yonezawa H, Sato G et al. 2015 - Revision of the Massarineae (Pleosporales, Dothideomycetes). Studies in Mycology 82, 75-136.

Thambugala KM, Daranagama DA, Phillips AJ, Bulgakov TS et al. 2017 - Microfungi on Tamarix. Fungal Diversity 82, 239-306.

Thambugala KM, Hyde KD, Tanaka K, Tian Q et al. 2015 - Towards a natural classification and backbonetree for Lophiostomataceae, Floricolaceae, and Amorosiaceae fam. nov. Fungal Diversity 74, 199-266.

Tibpromma S, Hyde KD, Jeewon R, Maharachchikumbura SSN et al. 2017 - Fungal diversity notes 491-602: taxonomic and phylogenetic contributions to fungal taxa. Fungal Diversity 83, $1-$ 261.

Tomioka K, Sato T, Sasaya T, Koganezawa H. 1997 - Leaf spot of kalanchoe caused by Stemphylium lycopersici. Annals of the Phytopathological Society of Japan 63, 337-340.

Tomioka K, Sato T. 2011 - Fruit rot of sweet pepper caused by Stemphylium lycopersici in Japan. Journal of General Plant Pathology 77, 342-344.

Torres MS, White JJF, Cazares G, Bergen M et al. 2005 - A new species and its phylogenetic placement in the Didymella/Phoma complex (Phaeosphaeriaceae, Pleosporales). Mycotaxon 93, 297-308.

Vakalounakis DJ, Markakis EA. 2013 - First report of Stemphylium solani as the causal agent of a leaf spot on greenhouse cucumber. Plant Diversity 97, 287-288.

Vilgalys R, Hester M. 1990 - Rapid genetic identification and mapping of enzymatically amplified ribosomal DNA from several Cryptococcus species. Journal of Bacteriology 172, 4238-4243.

Voronin LV. 1989 - Phoma Sacc. species from the water and fish of freshwater reservoirs. Mikologia i Fitopatologia 23, 19-27.

Wanasinghe DN, Jeewon R, EBG Jones, S Boonmee et al. 2018a - Novel palmicolous taxa within Pleosporales: Multigene phylogeny and taxonomic circumscription. Mycological Progress 17, 571-590.

Wanasinghe DN, Camporesi E, Hu DM. 2016 - Neoleptosphaeria jonesii sp. nov., a novel saprobic sexual species, in Leptosphaeriaceae. Mycosphere 7, 1368-1377.

Wanasinghe DN, Hyde KD, Jeewon R, Crous PW et al. 2017a - Phylogenetic revision of Camarosporium (Pleosporineae, Dothideomycetes) and allied genera. Studies in Mycology 87, 207-256.

Wanasinghe DN, Jeewon R, Jones EBG, Tibpromma S Hyde KD. 2017b - Saprobic Dothideomycetes in Thailand: Muritestudina gen. et sp. nov. (Testudinaceae) a new terrestrial pleosporalean ascomycete, with hyaline and muriform ascospores. Studies in Fungi 2, 219-234.

Wanasinghe DN, Jones EBG, Camporesi E, Boonmee S et al. 2014 - An exciting novel member of Lentitheciaceae in Italy from Clematis vitalba. Cryptogamie, Mycologie 35, 323-337.

Wanasinghe DN, Phukhamsakda C, Hyde KD, Jeewon R et al. 2018b - Fungal diversity notes 709839: taxonomic and phylogenetic contributions to fungal taxa with an emphasis on fungi on Rosaceae. Fungal Diversity 89, 1-236.

Wang HK, Aproot A, Crous PW, Hyde KD, Jeewon R. 2007 - The polyphyletic nature of Pleosporales: An example from Massariosphaeria based on ribosomal DNA and RBP2 gene phylogenies. Fungal Biology 111, 1268-1276.

White TJ, Bruns T, Lee S, Taylor J. 1990 - Amplification and direct sequencing of fungal ribosomal RNA genes for phylogenetics. In: Innis MA, Gelfand DH, Sninsky JJ, White TJ (eds) PCR protocols: a guide to methods and applications. Academic Press, San Diego 315322.

Wijayawardene NN, Crous PW, Kirk PM, Hawksworth DL et al. 2014 - Naming and outline of Dothideomycetes - including proposals for the protection or suppression of generic names. Fungal Diversity 69, 1-55.

Wijayawardene NN, Hyde KD, Al-Ani LKT, Tedersoo L et al. 2020 - Outline of Fungi and fungilike taxa. Mycosphere 11, 1060-1456. 
Wijayawardene NN, Hyde KD, Rajeshkumar KC, Hawksworth DL et al. 2017 - Notes for genera Ascomycota. Fungal Diversity 86, 1-594.

Wijayawardene NN, Hyde KD, Lumbsch HT, Jian KL et al. 2018 - Outline of ascomycota: 2017. Fungal Diversity 88, 167-263.

Wijayawardene NN, Hyde KD, Wanasinghe DN, Papizadeh M et al. 2016 - Taxonomy and phylogeny of dematiaceous coelomycetes. Fungal diversity 77, 1-316.

Woudenberg JHC, Groenewald JZ, Binder M, Crous PW. 2013 - Alternaria redefined. Studies in Mycology 75, 171-212.

Woudenberg JH, Seidl MF, Groenewald JZ, De Vries M et al. 2015 - Alternaria section Alternaria: Species, formae speciales or pathotypes?. Studies in Mycology 82, 1-21.

Woudenberg JHC, Hanse B, Van Leeuwen GCM, Groenewald JZ, Crous PW. 2017 - Stemphylium revisited. Studies in Mycology 87, 77-103.

Xianshu Y, Strobel G, Stierle A, Hess WM et al. 1994 - A fungal endophyte-tree relationship: Phoma sp. in Taxus wallachiana. Plant Science 102, 1-9.

Yang Q, Chen WY, Jiang N, Tian CM. 2019 - Nectria-related fungi causing dieback and canker diseases in China with Neothyronectria citri sp. nov. described. MycoKeys 56, 49-66.

Yarden O, Ainsworth TD, Roff G, Leggat W et al. 2007 - Increased prevalence of ubiquitous ascomycetes in an acropoid coral (Acropora formosa) exhibiting symptoms of brown band syndrome and skeletal eroding band. Applied \& Environmental Microbiology 73, 2755-2757.

Zeng XY, Jeewon R, Wen TC, Hongsanan S et al. 2018 - Simplified and efficient DNA extraction protocol for Meliolaceae specimens. Mycological Progress 17, 403-415.

Zhang KK, Hongsanan S, Tennakoon DS, Tian SL, Xie N. 2019 - Phaeosphaeria chinensis sp. nov. (Phaeosphaeriaceae) with an asexual/sexual morph connection from GuangDong Province, China. Phytotaxa 419, 28-38.

Zhang Y, Crous PW, Schoch CL, Hyde KD. 2012 - Pleosporales. Fungal Diversity 53, 1-221.

Zhang Y, Fournier J, Phookamsak R, Bakhali AH, Hyde KD. 2013 - Halotthiaceae fam. nov. (Pleosporales) accommodates the new genus Phaeoseptum and several other aquatic genera. Mycologia 40, 107-110.

Zhang Y, Zhang J, Wang Z, Fournier J et al. 2014 - Neotypifcation and phylogeny of Kalmusia. Phytotaxa 176, 64-173.

Zhang Y, Jeewon R, Fournier J, Hyde KD. 2008 - Multi-gene phylogeny and morphotaxonomy of Amniculicola lignicola: novel freshwater fungus from France and its relationships to the Pleosporales. Fungal Biology 112, 1186-1194.

Zhang Y, Schoch CL, Fournier J, Crous PW et al. 2009 - Multi-locus phylogeny of the Pleosporales: a taxonomic, ecological and evolutionary reevaluation. Studies in Mycology 64, 85-102.

Zhaxybayeva O, Gogarten JP. 2002 - Bootstrap, Bayesian probability and maximum likelihood mapping: exploring new tools for comparative genome analyses. BMC genomics 3, 4 . 